\title{
Manufacturing Consensus? New Zealand Press Attitudes Toward the Labour Movement in 1890
}

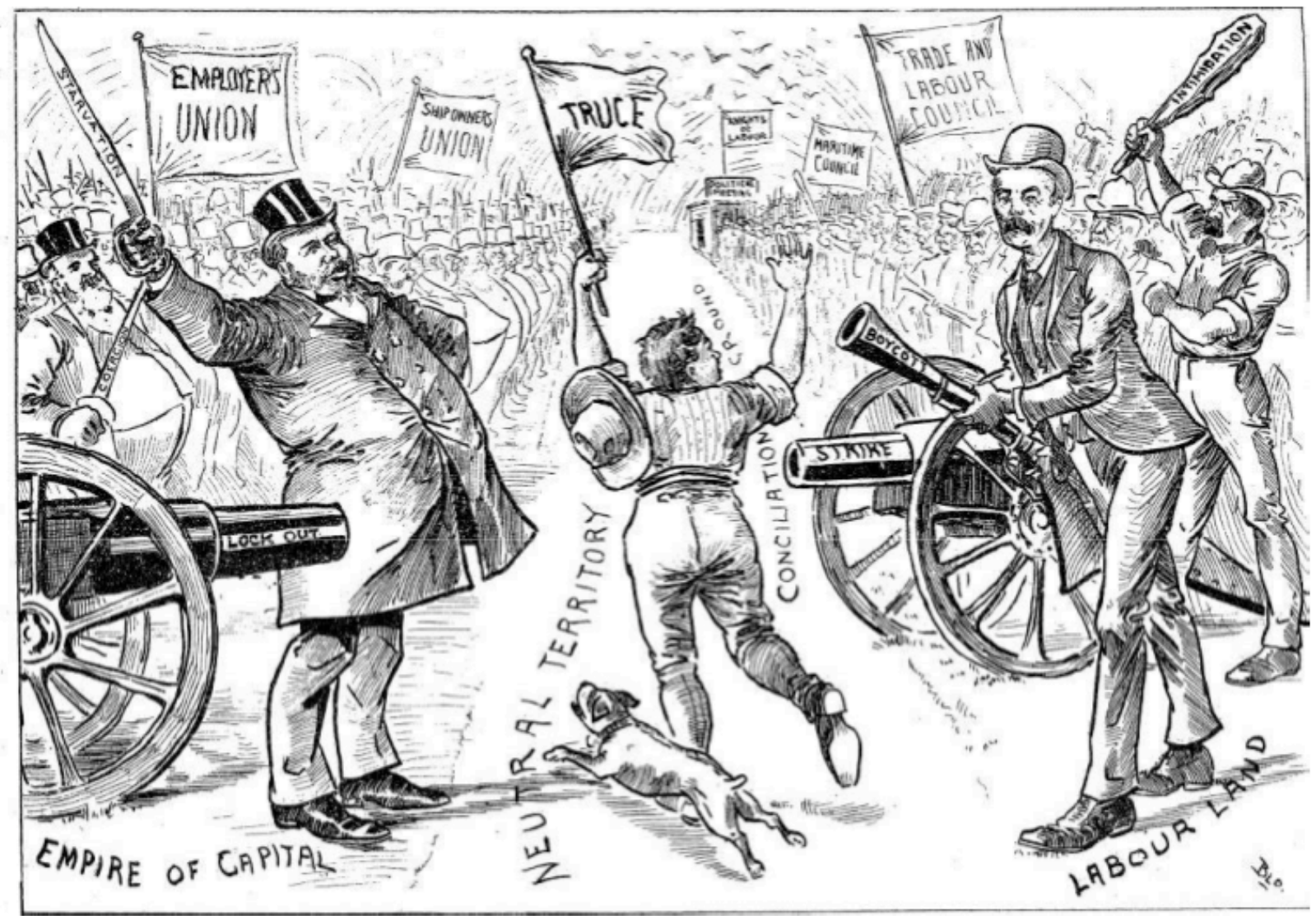

James Keating

A thesis submitted to Victoria University of Wellington in fulfilment of the requirements for the degree of Master of Arts in History

Victoria University of Wellington 
Cover picture from New Zealand Observer and Freelance, 6 September 1890, unpaged clipping, Herbert Otto Roth Papers, MS-Papers 94-10629/04, Alexander Turnbull Library. 


\section{Abstract}

This thesis investigates the attitudes of New Zealand newspapers to the social and economic tensions exacerbated by the emergence of a newly assertive labour movement in 1890, culminating in the August-November Maritime Strike, and the 5 December General Election. Through detailed analysis of labour reporting in six newspapers (Evening Post, Grey River Argus, Lyttelton Times, New Zealand Herald, Otago Daily Times, Press) this thesis examines contemporary conceptions of New Zealand society and editors' expectations of trade unions in a colony that emphasised its egalitarian mythology. Although the establishment of a national press agency in 1880 homogenised the distribution of national and international news, this study focuses on local news and editorial columns, which generally reflected proprietors' political leanings. Through these sites of ideological contest, conflicting representations of the ascendant trade union movement became apparent. While New Zealand newspapers sympathised with the striking London dockers in 1889, the advent of domestic industrial tensions provoked a wider range of reactions in the press. Strikes assumed a national significance, and the divisions between liberal and conservative newspapers narrowed. To varying degrees both considered militant action by organised labour a threat to the colony's peace and prosperity - sentiments that pervaded their reporting. The New Zealand Maritime Strike confirmed these prejudices and calcified the perception of organised labour's malevolence. Despite the year's upheavals, this thesis contends that the press struggled to comprehend labour's political ambitions, ignoring the unprecedented mobilisation of thousands of new voters, shifting public opinion, and the transformative impact of electoral reform. Distracted by the mainstream political obsession with land reform and convinced that public prejudices, stoked by their own reporting, would obviate a labour presence in the new parliament, the victory of the Liberal-labour coalition confounded the publishing establishment. 


\section{Table of Contents}

Abstract ii

Acknowledgements iv

List of Tables $\quad \mathrm{V}$

List of Abbreviations vi

$\begin{array}{ll}\text { Introduction } & 1\end{array}$

Chapter One: New Zealand's Economy and Society, An Overview $1850-1890$

Chapter Two: 'The Trade Unions are on their trial': Precursors to the Maritime Strike in New Zealand

Chapter Three: Entangling Alliances? The Arrival of the Maritime Strike in New Zealand

Chapter Four: From the Pit into Parliament? Organised Labour and the General Election

Conclusion

Appendix One: Employers' Associations, 1890

Appendix Two: Liberal/Labour General Election Manifestos, August-November 1890

Bibliography 


\section{Acknowledgements}

During the year spent researching and writing this thesis I was fortunate to receive support and assistance from a number of people. This work has been greatly enriched by their contributions; however, the remaining failings are my own.

Firstly, I gratefully acknowledge the guidance of my supervisor, Jim McAloon, who generously gave his time and wisdom to this project. His thoughtful contributions consistently pushed me in new directions and sharpened my arguments.

Thanks to the History Department, and in particular my fellow post-graduate students, for providing a stimulating and accommodating working environment. Though now in the United States, Evan Roberts remained a generous source of advice and inspiration. I am grateful to Victoria University for awarding me a Masters Scholarship, which funded this thesis, and for the John F. Kennedy Prize, which enabled me to visit archives in Christchurch. I also wish to recognise the assistance of staff at the Alexander Turnbull Library, Archives New Zealand, Christchurch Public Library, National Library of New Zealand, and the Victoria University Library.

Finally, I thank my family and friends for their love, forbearance, and support, without which this thesis would be greatly diminished. Above all, to Katie Grant, whose insight, interest, and patience were invaluable. 


\section{List of Tables}

Table One: Newspapers' estimates of the number of workers on strike, September 1890. 


\section{List of Abbreviations}

AMA

AMALA

ASU

ASRS

ATL

CMPA

CTA

EP

FSU

GRA

GVCC

GVMA

LPC

$L T$

MHR

MMOA

$\mathrm{NZH}$

NZJH

$O D T$

PPA

SSOA

TLC

UPA

WCC

WMOU

WMPA

WWC
Amalgamated Miners' Association

Amalgamated Miners' and Labourers' Association

Amalgamated Shearers' Union

Amalgamated Society of Railway Servants

Alexander Turnbull Library

Canterbury Master Printers' Association

Canterbury Typographical Association

Evening Post

Federated Seamen's Union

Grey River Argus

Grey Valley Colliery Company

Grey Valley Miners' Association

Labour Parliamentary Committee

Lyttelton Times

Member of the House of Representatives

Mercantile Marine Officers' Association

New Zealand Herald

New Zealand Journal of History

Otago Daily Times

People's Political Association

Steam Ship Owners' Association

Trades and Labour Council

United Press Association

Westport Colliery Company

Woollen Mill Operatives’ Union

Working Men's Political Association

Wellington Woollen Company 


\section{Introduction}

On 8 September 1890, the Canterbury financier George Gatonby Stead purchased the Christchurch Press. While aspects of the acquisition remain shrouded in mystery, the paper's financial difficulties were well documented. Intense competition with rival publications during the 1870 s and 1880 s saw the Press suffer heavy losses. Despite healthy circulation figures, stock issues in the 1880 s failed to ameliorate the newspaper's problems - in 1887 the Press ran an operating loss of $£ 4,926$ and accrued debts of over $£ 10,000 .^{1}$ The company chairman, R.J.S. Harman, directed a programme of aggressive expansion, enlarging the newspaper from four to eight pages in 1887. Harman's buccaneering management merely prolonged the Press' decline. By June 1890 , the company required additional investment of $£ 20,000$ to continue printing. The directorate proposed the creation of a new company to manage the Press, Weekly Press, and Truth, and sought buyers. Negotiations with Stead began in August, and the Christchurch Press Company opened for business early the next month. ${ }^{2}$

R.B. O'Neil, the company's official historian, characterised George Stead's intervention as an act of benevolence, linking the financier's purchase to his formative experiences as a racing correspondent in the 1860s. More cynical interpretations of the acquisition that 'took the business community by surprise and evoked admiration and envy' are not hard to imagine. ${ }^{3}$ Just two months later, Stead announced his candidacy for the Avon seat in the December General Election. In the intervening months he assumed a prominent role in Canterbury society, joining the

\footnotetext{
${ }^{1}$ In 1882, the circulation of the Press stood at 5,000. D.R. Harvey, 'Circulation Figures of Some Nineteenth Century New Zealand Newspapers', Archifacts [Bulletin of the Archives and Records Association of New Zealand], December 1988 and March 1989, p.26; R.B. O'Neil, The Press 18611961: The Story of a Newspaper, Christchurch: Christchurch Press Company Limited, 1963, pp.10506.

${ }^{2}$ O'Neil, The Press, pp.106-08.

${ }^{3}$ ibid., p.107.
} 
executive of the newly formed Employers' Association and organising the campaign to reopen the Lyttelton wharves with volunteer labour during the Maritime Strike. ${ }^{4}$ By acquiring a newspaper, Stead hoped to join the illustrious list of politicians who had served as newspapermen. While this tradition had faded, the lines between journalist and politician remained hazy - two of Stead's contemporaries, John Ballance and William Pember Reeves, owned newspapers that extended their political 'voice' far beyond the debating chamber.

A few months before Stead's purchase, John Millar, President of the Maritime Council, proposed the publication of a weekly tabloid, Labour. At the Council's biannual meeting in May, he unveiled a dummy edition, hoping to persuade the executive to fund the enterprise. His editorial stance was clear - under the masthead ran the socialist axiom: 'From each according to his ability, to each according to his needs' ${ }^{5}$ Although unionists circulated Australian, British, and American periodicals, New Zealand workers had been without a newspaper since the collapse of the shortlived weekly, the Watchman (1884-1886). ${ }^{6}$ Millar envisaged the Council as an institution to promote labour solidarity, and recognised that the inability to communicate with the newly mobilised community of trade unionists obstructed the progress of industrial reform and the development of class consciousness. Despite Millar's noble intentions, the journal never reached publication. Delegates voted to postpone the launch of Labour until it could be assured a sound financial future. Some months later the Maritime Council entered into a fatal industrial battle.

These competing efforts to enter the newspaper industry occurred during a turbulent period in New Zealand history. The colony's troubled emergence from a

\footnotetext{
${ }^{4}$ Lyttelton Times (LT), 30 August 1890, p.6; Star, 6 September 1890, p.3.

${ }^{5}$ Conrad Bollinger, Against the Wind: the Story of the New Zealand Seamen's Union, Wellington: New Zealand Seamen's Union, 1968, pp.34-35.

${ }^{6}$ On 18 October 1890, the radical journalist Arthur Desmond established the Tribune, a labour weekly. Yet the paper collapsed in early December after just eight issues. Bert Roth, 'A History of Socialist Newspapers in New Zealand', Socialist Action, Vol. 8, no.7, May 1976, p.4.
} 
prolonged economic depression that began in 1879 revealed deep tensions regarding the nature and future of New Zealand society. Prompted by a brief economic revival, trade unions underwent an extraordinary transformation, with membership soaring from under 3,000 to more than 20,000 in 18 months. ${ }^{7}$ These unions were organised along new principles - imported from Europe, North America, and Australia - which saw thousands of unskilled workers federated into large conglomerates. The rise of new unionism, with its focus on redressing the power imbalance between labour and management, as well as improving working conditions and living standards via mass organisation and collective action, engendered animosity between workers and employers - a conflict initially ignored, then exaggerated by the press. After a series of regional disputes in which capital and labour contested these objectives, the Maritime Strike began on 26 August 1890. The strike originated in Australia, but spread to New Zealand when unionists stopped work to protest domestic shipowners' boycott of union labour. Fearing an attempt to eliminate the union presence in New Zealand, the Maritime Council - the first colony-wide labour federation advised its affiliates to boycott domestic and inter-colonial shipping and coal mining until ship-owners negotiated a settlement. Despite the unionists' optimism, the strike soon failed. Trade unions had made huge gains in the preceding two years, yet they were unprepared for a confrontation with the colony's largest companies, and the groundswell of public animosity stirred up by a hostile press.

Increased industrial unrest catalysed the discussion of deeper grievances regarding social structure - debates that coloured reporting of labour issues in 1890 . For workers, small farmers, and middle-class radicals, the depression shattered the

\footnotetext{
7 Tony Simpson, 'The Holt Narrative and the Industrial Relations Agenda', New Zealand Journal of Industrial Relations, Vol. 12, no. 3, 1987, p.147.
} 
twin myths of consensus and egalitarianism, deeply embedded in the Pākehā psyche. ${ }^{8}$ By the late 1880 s, a growing portion of society, represented by the nascent Liberal party, believed that land tenure reform, specifically breaking the large estates, was necessary for New Zealand to remain a society that rewarded industry with opportunity and advancement. ${ }^{9}$ Labour fit uneasily into this new paradigm. Although the Liberals, supported by their allies in the press, sympathised with trade unions' demands for industrial reform, they believed closer land settlement would ameliorate the colony's problems, including industrial unrest. ${ }^{10}$ Yet, despite growing public discontent, most newspapers refused to consider the labour movement as anything other than a vehicle for the advancement of pernicious agitators. Refusing to abandon the vision of New Zealand as a land of equal opportunity, free from entrenched privilege, newspaper editors perceived the emergence of class agitation as evidence that greedy organisers had duped workers into harming their own interests. ${ }^{11}$ During the December General Election, these competing interpretations played out in electorates across New Zealand, as voters decided between the Atkinson Government's measured approach, and the Liberals' promise of reform.

This thesis examines the newspaper coverage of labour issues in New Zealand, analysing evolving responses to the unprecedented coalition of trade unionists that formed an important, if overlooked, component of the liberal ascendancy in 1890 . Reporting on labour issues was coloured by two conflicting conceptions of New

\footnotetext{
${ }^{8}$ Bob Consedine, 'Inequality and the Egalitarian Myth', in David Novitz and Bill Willmott (eds.), Culture and Identity in New Zealand, Wellington: GP Books, 1989, p.172; Melanie Nolan, 'The Reality and Myth of New Zealand Egalitarianism: Explaining the Pattern of a Labour Historiography at the Edge of Empires', Labour History Review, Vol. 72, no. 2, August 2007, pp.113-34.

9 John E. Martin, The House: New Zealand's House of Representatives 1854-2004, Palmerston North: Dunmore Press, 2004, p.103.

${ }^{10}$ David Hamer, The New Zealand Liberals: The Years of Power, 1891-1912, Auckland: Auckland University Press, 1988, pp.56-58; Timothy McIvor, The Rainmaker: A Biography of John Ballance, Journalist and Politician 1839-1893, Auckland: Heineman Reed, 1989, p.167

${ }^{11}$ Jeanine Graham, 'Settler Society', in W.H. Oliver and B.R. Williams (eds.), The Oxford History of New Zealand, Auckland: Oxford University Press, 1981, pp.137-38.
} 
Zealand society. The first was the notion of the colony as an egalitarian society, free from 'old-world' evils (including both worker exploitation and class consciousness). Coverage of the 1889 London Dock Strike and 1890 Sweating Commission displayed sincere compassion and a determination to eradicate the worst excesses of industrial capitalism. Yet, challenged by a labour movement eager to assert its influence in the workplace, a stronger commitment to order, consensus, and moderation tempered such sympathies. Although editors agonised over the suffering of London's dockers, they remained wary of the power and ambition of federated labour.

Increased industrial unrest in the autumn and winter of 1890 exacerbated this tension as the press continued to espouse the principles of trade unionism, while condemning their practice. Striking for improved conditions fell outside the limits expected of unions, and was considered greedy and opportunistic. Newspapers across the political spectrum averred that labour should accept inequity with forbearance, which would eventually attract public notice and support. Although this seldom transpired, newspapers used New Zealand's reputation as a worker's paradise to stifle the demands of a frustrated labour movement. However, the coverage of the 1890 General Election raises the question whether the antagonism of the press can be considered a cynical endeavour to maintain the status quo or an indication of the divergence between elite opinion and the concerns of the wider population. Once campaigning began, the press, with few exceptions, dismissed the Opposition's chances of success - confident that the Maritime Strike had demonstrated the dangers of radicalism. The conviction that the public would shun labour-leaning politicians was so ingrained that newspapers only seriously considered the possibility of a Liberal victory in the final weeks of the campaign. Having assured readers for months that trade unions occupied a marginal social position, editors underestimated the 
Opposition's popularity amongst professionals and rural smallholders, as well as urban workers.

Previous studies of New Zealand newspapers in 1890 limited their focus to comparisons between the liberal Lyttelton Times and the conservative Press. Laurel Hepburn uses the contrast between those newspapers to bolster her argument that newspapers were 'ideological protagonist[s]' on behalf of their proprietors. ${ }^{12}$ Similarly, Ian Merrett notes that the 'widely divergent' views of the two Christchurch dailies broadly represented colonial opinions. ${ }^{13}$ James Taylor, however, argues that a narrow focus on two polarised newspapers is a common flaw in New Zealand historians' use of newspapers to illuminate social debates. ${ }^{14}$ By contrast, in his study of the relationship between the Australian media and union funding during the 1889 London Dock Strike and 1890 Maritime Strike, R.B. Walker cast a wider net, analysing coverage from a wide range of regional newspapers. ${ }^{15}$ Given the number of metropolitan and regional newspapers in the 1880s, a wider analysis must be undertaken before any sound conclusions are reached. I have based my research around six daily newspapers (New Zealand Herald, Evening Post, Grey River Argus, Lyttelton Times, Press, and Otago Daily Times) located across the colony and encompassing a broad spectrum of political affiliations.

The New Zealand newspaper industry began in 1840 with the first domestic printing of the New Zealand Gazette and Wellington Spectator, and inaugural

\footnotetext{
${ }^{12}$ Laurel Elizabeth Hepburn, 'The Attitudes of the Newspapers in Canterbury to the Emergent Labour Movement, and Related Issues, from 1885 to 1890 ', MA thesis, University of Canterbury, 1985, p.159. ${ }^{13}$ Ian A. Merrett, 'A Reappraisal of the 1890 Maritime Strike in New Zealand', MA thesis, University of Canterbury, 1969, p.258.

${ }^{14}$ James Taylor, 'Contemporary Media Portrayals of the 1913 Dispute', in Melanie Nolan (ed.) Revolution: The 1913 Great Strike in New Zealand, Christchurch: Canterbury University Press, 2005, p. 143 .

${ }^{15}$ R.B. Walker, 'Media and Money: The London Dock Strike of 1889 and the Australian Maritime Strike of 1890', Labour History, no. 41, November 1981, pp.41-56.
} 
publication of the New Zealand Advertiser and Bay of Islands Gazette in Russell. As settlement spread, newspapers began publication in major provincial towns: New Zealand Herald and Auckland Gazette, 1841; Nelson Examiner, 1842; Otago News, 1848; Lyttelton Times, 1851; Taranaki Herald, 1852. Early newspapers were hindered by low population density, scarcity of equipment, and government interference. The Crown Colony administration punished its critics by withdrawing advertising contracts, confiscating presses, and foreclosing printers. ${ }^{16}$ The economic and demographic boom of the 1860s allowed newspapers to become profitable, and prompted the transition to daily editions - reducing the reliance on government advertising. The Otago Daily Times and Christchurch Press were both founded in 1861, followed by a new New Zealand Herald in 1863, and Wellington's Evening Post in 1865 . Despite early tribulations, by 1865 annual aggregate circulation exceeded five million in a colony with a Pākehā population of $171,000 .{ }^{17}$

Political motives often spurred the formation of a newspaper. William Wilson, the former proprietor of the New Zealander, founded the New Zealand Herald on 13 November 1863 following an ideological dispute over the Taranaki and Waikato wars. While his partner John Williamson advocated a philo-Māori policy, Wilson favoured 'vigorous prosecution' - forcing Māori submission to the Crown. ${ }^{18}$ Initially the Herald favoured a strong military approach, yet the paper quickly became more aligned to prevailing public opinion. Although a political disagreement instigated the Herald's inception, Guy Scholefield deemed the paper a 'striking example of a

\footnotetext{
${ }^{16}$ Patrick Day, The Making of the New Zealand Press 1840-1800: A Study of the Organizational and Political Concerns of New Zealand Newspaper Controllers, Wellington: Victoria University Press, 1990, pp.12-34.

${ }^{17}$ S.W. Bradley, Newspapers: An Analysis of the Press in New Zealand, Auckland: Heinemann Educational Books, 1973, p.5; David C. Thorns and Charles P. Sedgwick, Understanding Aotearoa/New Zealand: Historical Statistics, Palmerston North: Dunmore Press, 1997, p.32.

${ }^{18}$ Day, The Making of the New Zealand Press, p.133.
} 
newspaper founded as a business rather than a political organ'. ${ }^{19}$ In the $1880 \mathrm{~s}$ the paper flourished, boasting an average daily circulation of $6,350 .^{20}$ Politically, the Herald supported the Grey, Stout-Vogel, and Atkinson Governments, but became a prominent critic of the Liberal administration after 1890 .

Dublin journalist Henry Blundell established the Evening Post as Wellington's first daily newspaper in 1865 . The newspaper was a family business; Henry served as editor, while his sons Henry, John, and Louis worked as typesetter, canvasser, and reporter respectively. Fiercely independent, Blundell followed 'a liberal course of policy', and eschewed political office to uphold the newspaper's integrity. ${ }^{21}$ The paper opposed successive governments in the 1870s and 1880s, but endorsed the nascent Liberal coalition in $1890 .^{22}$ With a strong local focus, the Post dominated the Wellington newspaper market, withstanding competition from an assortment of new publications in the 1860s and 1870s. In 1890 the paper published six editions weekly, and reported a daily circulation of $8,000 .^{23}$

Scottish publisher James Kerr launched the Grey River Argus in November 1865. Initially, the newspaper was published tri-weekly, but entered daily production in 1871. Under the stewardship of William Henry Harrison (1868-1879) and Florence Romuald McCarthy (1880-1914), the Argus developed a reputation for outstanding journalism. In an era when artisan values were incongruent with the values of the mainstream press, the Argus was notable for its support of the labour movement. ${ }^{24}$ Advocacy of artisan radicalism saw the Argus come into conflict with its conservative rival, the Greymouth Evening Star, which began publishing in 1866. By the early

\footnotetext{
${ }^{19}$ Guy H. Scholefield, Newspapers in New Zealand, Wellington: A.H. \& A.W. Reed, 1958, p.83.

${ }^{20}$ Ross Harvey, 'The Power of the Press in Colonial New Zealand: More Imagined Than Real?', Bibliographical Society of Australia and New Zealand Bulletin, Vol. 17, no. 2, 1993, pp.137-38.

${ }^{21}$ Evening Post (EP), 8 February 1865, p.2.

${ }^{22}$ Day, The Making of the New Zealand Press, p.163.

${ }^{23}$ EP, 7 February 1890, p.2.

${ }^{24}$ Day, The Making of the New Zealand Press, p.243.
} 
1880s, the average daily circulation of the Argus fluctuated between 740 and 1,050 copies. $^{25}$

The Lyttelton Times was established in 1851, funded by prospective Canterbury colonists. The newspaper quickly suffered financial difficulties and soon came under private ownership. Appointed as general manager in 1861, by 1867 William Reeves had become the proprietor and editor of the Times, and developed the newspaper's reputation as an 'advocate of the rights and liberties of the people'. ${ }^{26}$ Reeves' son, William Pember Reeves, began writing for the newspaper in 1882, and later became a correspondent on the House of Representatives. Over the next decade Pember Reeves gradually accumulated responsibility at the Times, becoming editor in 1889 . The Times' fierce rivalry with the Press hurt the former financially - between 1882 and 1886, profits fell from $£ 8,400$ to $£ 5,100 .^{27}$ Nevertheless, in 1890 , the Times was among the colony's highest selling newspapers, boasting a daily circulation of over $7,600 .^{28}$

The Christchurch Press was first published on 25 May 1861 by former Lyttelton Times editor James FitzGerald. Backed by Canterbury's 'pastoral elite', FitzGerald established the newspaper to protest the Times' support of the public works program initiated by Sefton Moorhouse, the Provincial Superintendent. ${ }^{29}$ From the outset, the paper was conservative, advocating economic austerity and defending the interests of its propertied owners. The Press quickly became a leading voice in colonial politics,

\footnotetext{
${ }^{25}$ Harvey, 'Circulation Figures of Some Nineteenth Century New Zealand Newspapers', p.22.

${ }^{26}$ The Cyclopedia of New Zealand [Canterbury Provincial District], Christchurch: Horace J. Weeks Ltd, 1903, p.238.

27 Keith Sinclair, William Pember Reeves: New Zealand Fabian, Oxford: Clarendon Press, 1965, pp.49-52, 68 .

${ }^{28} L T, 4$ September 1890, p.4.

${ }^{29}$ Hepburn, 'The Attitudes of the Newspapers in Canterbury', p.14.
} 
and by the 1880 s was regarded as 'the most Conservative...paper published in New Zealand' ${ }^{30}$

Julius Vogel founded the Otago Daily Times, New Zealand's first daily newspaper, on 15 November 1861. Heralding a new commercial era, Vogel imported a steam driven press from Britain in 1862. Early adoption of industrial methods saw the paper achieve enormous advances on previous circulation and profit margins. By 1863 the paper's circulation exceeded 7,000. However, the collapse of the Otago gold rush in the late 1860 s ended the prosperity that the Otago press had thrived on. Advertising revenue fell, and management worried that Vogel's political posturing exacerbated the paper's financial difficulties. At odds with the commercial requirements of the newspaper, Vogel was ousted from the editorship in 1868. Under new ownership the Otago Daily Times opposed the Vogel administration, but supported the Grey Government in $1878 .{ }^{31}$ By 1883 the paper's circulation had fallen to 4,650 , a result of fierce competition with Dunedin's two other major dailies, the Evening Star and Morning Herald. ${ }^{32}$

The emerging commercial potential of newspapers in the 1860 s changed the New Zealand press. Eager to maintain profitability, proprietors began restructuring their concerns on commercially sound principles. The introduction of the steam engine and cylindrical printing press allowed newspapers to reach broader audiences. Multiple newspapers competing in small metropolitan markets depressed prices, and eventually a mass 'penny press' replaced the old subscription model. ${ }^{33}$ Between 1860 and 1890 , as the population increased six-fold, the number of newspapers published

\footnotetext{
${ }^{30}$ O'Neil, The Press, p.100.

${ }^{31}$ Day, The Making of the New Zealand Press, pp.111-18.

${ }^{32}$ Harvey, 'Circulation Figures of Some Nineteenth Century New Zealand Newspapers', p.26.

${ }^{33}$ Day, The Making of the New Zealand Press, pp.174-76.
} 
in the colony soared from 20 to $122 .{ }^{34}$ Although the proliferation of newspapers coincided with the expansion of the literate population, New Zealand did not experience a 'democratisation' of its press. While the range of published news and opinion broadened, the hegemonic interests of the establishment - 'Pakeha property and provincial order' - remained ascendant. As Ruth Butterworth explains, 'worker and Maori concerns were conspicuously absent and consistently denigrated' (she might have added women to the list) in an industry committed to the maintenance of consensus. $^{35}$

Established in 1880, the United Press Association (UPA) amalgamated newspapers into a cohesive grouping 'that could appropriately be called the New Zealand press' ${ }^{36}$ A consolidation of the telegraph services established to utilise the trans-Tasman telegraph cable in 1876, the UPA monopolised access to international news through the Reuter's Telegram Company service. Affiliated newspapers were restricted to reporting on local events with regional news coverage provided by the Association. Although newspaper editors selected copy, the UPA effectively homogenised domestic and international news. ${ }^{37}$ Furthermore, by restricting access to the UPA telegraph to two newspapers in each town, members crushed their rivals by providing readers with exclusive content - at the expense of a democratic public culture. ${ }^{38}$ Thus, the editorial represented the clearest articulation of each newspaper's

\footnotetext{
${ }^{34}$ J.O. Wilson (ed.), A Union Catalogue of New Zealand Newspapers, Preserved in Public Libraries, Newspaper Offices, and Local Authority Offices, Wellington: General Assembly Library, 1938, $2^{\text {nd }}$ edition, 1961, pp.1-65; Thorns and Sedgwick, Understanding Aotearoa/New Zealand, pp.38, 65-66.

${ }^{35}$ Ruth Butterworth, 'The Media', in Novitz and Wilmott (eds.), Culture and Identity in New Zealand, p.146.

${ }^{36}$ Day, The Making of the New Zealand Press, p.237.

${ }^{37}$ Grant Hannis, 'The New Zealand Press Association 1880 - 2006: The Rise and Fall of a Cooperative Model for News Gathering', Australian Economic History Review, Vol. 48, no. 1, March 2008, p.53.

38 Although the anti-competitive nature of the telegraph cartel worried politicians, little was done to prevent the UPA from 'crushing' its rivals. See 'Press Telegrams Committee Report: Minutes of Evidence', Appendices to the Journals of the House of Representatives (AJHR), 1880, I-5, pp.1-37; Butterworth, 'The Media', in Novitz and Wilmott (eds.), Culture and Identity in New Zealand, p.145.
} 
'distinctive individualit[y]' - the major site of ideological contest in the late nineteenth century New Zealand press, and the focus of this study. ${ }^{39}$

George Stead's investment in an insolvent newspaper, and John Millar's struggle to establish a labour periodical offer several insights into the interaction between press and society in 1890 . The argument that economic imperatives subsumed partisanship during the 1860 s transition to a commercial press has been overstated. The emerging era of commercialisation combined patronage with cutthroat competition as newspaper proprietors negotiated the transition to a popular, mass media. Technological and educational advances allowed the press to reach wider audiences, yet few newspapers were profitable. ${ }^{40}$ Most newspapers' editorial policies lay between Laurel Hepburn's assertion that newspapers prioritised political rhetoric over reliable information, and Patrick Day's argument that economic rationality moderated political allegiances. ${ }^{41}$ The expansion of the newspaper market in the 1860s presented newspaper owners with a dilemma. Daily publication was an expensive enterprise, not always offset by the political opportunities afforded to the proprietor. As a general rule, in the $1880 \mathrm{~s}$ a metropolitan newspaper was not commercially viable unless it could maintain a circulation of $2,500 .^{42}$ To attract a broad readership, newspapers tempered their previous dogmatism. The realities of press activity rendered political biases inevitable, yet newspapers were no longer irrevocably committed to any individual politician.

\footnotetext{
39 Aled Jones, Powers of the Press: Newspapers, Power and the Public in Nineteenth-Century England, Aldershot: Scolar Press, 1996, p.88.

40 John Ballance and William Pember Reeves' struggles to keep their respective newspapers (the Wanganui Herald and the Lyttelton Times) solvent during the 1880s are well documented. McIvor, The Rainmaker, pp.107-08, 155-58; Sinclair, William Pember Reeves, pp.49-52, 128-30.

41 Day, The Making of the New Zealand Press, pp.134-136; Hepburn, 'The Attitudes of the Newspapers in Canterbury', p.24.

${ }^{42}$ Ross Harvey, 'Formula for Success: Economic Aspects of the Nineteenth-Century New Zealand Press', in R. Harvey, W. Kirsop, and B.J. McMullin (eds.), An Index of Civilisation: Studies of Printing and Publishing History in Honour of Keith Maslen, Clayton: Monash University Centre of Bibliographical and Textual Studies, 1993, p.211.
} 
By 1890, the newspaper was the most immediate and influential medium. The conviction that newspapers influenced society was widespread, particularly among those engaged in their ownership and production. Yet, the accumulation of power and assumption of political and moral leadership by the press was a recent phenomenon. As late as the 1860 s, information transmitted orally at the theatre, pulpit, and soapbox was, as Aled Jones has suggested for Britain, more powerful, engaging, and influential than printed text. By refusing to 'disseminate the outpourings of a nobody', the press established a hierarchy of voices, privileging the perspectives of editors and proprietors. ${ }^{43}$ As circulation figures entered the thousands in most major centres, newspapers became embedded in the culture. Alan Lee's statement that 'the [British] press in the nineteenth century was the most important single medium of the communication of ideas' is certainly applicable to New Zealand. ${ }^{44}$ Observing publishers' monopoly over the transmission of information in late nineteenth century Britain, Frank Taylor remarked that the newspaper was 'alone in its permanence'. Although he understood that newspapers rarely altered readers' convictions, he believed journalism formed opinions by giving 'shape to masses of half-articulate feeling, ${ }^{45}$ Certainly no other medium could influence mass audiences to the extent of the ubiquitous newspaper with its repetitive daily articulation of a partisan agenda.

British theories articulating the power of the nineteenth century press cannot be uncritically applied to colonial societies. New Zealand newspapers developed in emerging regional towns and small rural centres, not industrialising cities. Readerships were small - Ross Harvey estimates that between seven and 12 per cent

\footnotetext{
${ }^{43}$ Jones, Powers of the Press, pp.88, 180.

${ }^{44}$ Alan J. Lee, The Origins of the Popular Press in England 1855 - 1914, London: Croon Helm, 1976, p.18.

${ }^{45}$ Frank Taylor, The Newspaper Press as a Power both in the Expression and Formulation of Public Opinion, Oxford: B.H. Blackwell, 1898, pp.12-17.
} 
of the population 'saw' a newspaper in the late nineteenth century. ${ }^{46}$ Harvey is correct to note the relative minority of newspaper readers in New Zealand, but relegating domestic newspapers to mere local newsletters is misleading. Rollo Arnold argues that the press fostered a 'village and globe outlook', melding extensive local correspondence with global news and features. ${ }^{47}$ Newspapers published stories from across the world, while editorials established strong positions on colonial and international issues. J.E. Traue argues that New Zealand's fragile book and periodical culture gave newspapers 'a far more important role than their contemporaries in Britain and Europe' ${ }^{48}$ New Zealand did not have the mass reading market of Britain or America, but the ways in which domestic newspapers presented and framed stories, set agendas, and promoted solutions were nevertheless influential.

In a print culture, newspaper coverage strongly influences which issues are defined as 'important' by the public. The relative placement and degree of newspaper attention a story receives influence how it is understood and evaluated by audiences. ${ }^{49}$ Framing of news stories is used to engender public support or opposition to the actors, issues, and policies presented. Robert Entman defines framing as the selection and emphasis of 'some facets of events and issues, and making connections among them so as to promote a particular interpretation, evaluation and/or solution'. ${ }^{50}$ Frames increase the salience of information within a text, rendering it more noticeable to reading audiences. ${ }^{51}$ The two essential elements of a frame are defining

\footnotetext{
${ }^{46}$ Harvey, 'The Power of the Press in Colonial New Zealand', pp.137-38.

${ }^{47}$ Rollo Arnold, New Zealand's Burning: The Settlers' World in the Mid 1880s, Wellington: Victoria University Press, 1994, p.220.

48 J.E. Traue, 'But Why Mulgan, Marris and Schroder?: The Mutation of the Local Newspaper in New Zealand's Colonial Print Culture', Bibliographical Society of Australia and New Zealand Bulletin, Vol. 21, no. 2, 1997, p.115.

${ }^{49}$ Dietram A. Scheufele and David Tewksbury, 'Framing, Agenda Setting, and Printing: The Evolution of Three Media Effects Models', Journal of Communication, Vol. 57, no. 1, March 2007, p.11.

${ }^{50}$ Robert M. Entman, Projections of Power: Framing News, Public Opinion and U.S. Foreign Policy, Chicago, 2004, p.5.

${ }^{51}$ Robert M. Entman, 'Framing Bias: Media in the Distribution of Power', Journal of Communication, Vol. 57, no. 1, March 2007, p.164.
} 
a problem, which sets the agenda for the frame, and outlining a remedy, which promotes support or opposition to a policy or actor. Frames are constituted by groups of words and images that stimulate a particular reaction to actors in a political conflict. Entman states that frames that connect culturally resonant terms and use emotive language are easily noticeable and understandable. The 'magnitude' of a frame is increased by the repetition of framing language and its resonance with preexisting ideas, information, and convictions of an audience. ${ }^{52}$

While this basic approach to frame analysis is broadly applicable, serious difficulties exist in adapting contemporary media theory to nineteenth century New Zealand newspapers. The methods of analysis remain useful, but the context presents significant challenges. In 1890, the press remained a fractious and barely cohesive body. Frames did not filter down through a hierarchy of news organisations, as Entman suggests, because no such hierarchy existed (the UPA standardised news dissemination rather than influencing newspapers' editorial decisions). ${ }^{53}$ Newsgathering was localised, and editors rarely reprinted or extracted copy from 'elite' or influential publications. Despite the small domestic reading audience, there is good reason to think that news frames resonated strongly in the $1880 \mathrm{~s}$, as newspapers monopolised the transmission of information in an era before the advent of audio and visual mass communications. The lines between journalist, politician, and scholar were blurred, and Ross Harvey argues that the 'heavy representation' of newspapermen in the House of Representatives was unsurprising given UPA members' exclusive access to domestic and international news. ${ }^{54}$

\footnotetext{
${ }^{52}$ Scheufele and Tewksbury, 'Framing, Agenda Setting, And Printing', p.11.

${ }^{53}$ Entman, Projections of Power, pp.9-22.

${ }^{54}$ Mark Hampton, Visions of the Press in Britain, 1850-1950, Urbana: University of Illinois Press, 2004, p.7; Ross Harvey, 'Bringing the News to New Zealand: The Supply and Control of Overseas News in the Nineteenth Century', Media History, Vol. 8, no. 1, 2002, p.21.
} 
Historians studying the rise of and reaction to American liberalism in the 'Gilded Age' have demonstrated the value of examining newspapers' role in the late nineteenth emergence of progressivism. In The Reconstruction of American Liberalism, Nancy Cohen emphasises the role of newspapers as vectors through which liberal reformers influenced the public sphere. ${ }^{55}$ Writing on the capitalist mobilisation against such reformers, Jeffrey Haydu defines frames broadly, as sets of ideas and attitudes that not only shaped print journalism, but also deeply permeated American society. ${ }^{56}$ Although the late nineteenth century New Zealand press has been a popular research subject for the last thirty years, historians and media theorists have predominantly addressed 'the press' as a coherent body. As a result, much is known about newspapers' ownership, financing, and organisational structures, yet we understand rather less about the news itself - the production these organisations engaged in. James Taylor's excellent study of the coverage of the 1913 Great Strike remains a notable exception. ${ }^{57}$ Through an analysis of the daily news and editorial coverage produced by newspapers in 1890, this thesis will address gaps in our understanding of the interaction between press and society, the representation of the emerging labour movement, and the disjuncture between elite perceptions of New Zealand and the rumblings of dissatisfied artisans, labourers, farmers, and radicals.

The discussion is organised into four chronological chapters. The first situates the events of 1890 within the economic upheavals of the late nineteenth century, examines the rise of organised labour in New Zealand, and provides a historiographical framework for considering 1890. The second chapter analyses newspaper coverage of industrial unrest in the first half of 1890, and looks at the

\footnotetext{
${ }^{55}$ Nancy Cohen, The Reconstruction of American Liberalism, 1865-1914, Chapel Hill and London: University of North Carolina Press, 2002.

${ }^{56}$ Jeffrey Haydu, 'Counter Action Frames: Employer Repertoires and the Union Menace in the Late Nineteenth Century’, Social Problems, Vol. 46, no. 3, August 1999, pp.313-31.

57 Taylor, ' Contemporary Media Portrayals of the 1913 Dispute', in Nolan (ed.), Revolution, pp.14263.
} 
growing hostility directed at newly assertive trade unions. By late July, this hostility had evolved into undisguised anger. Chapter three assesses coverage of the Whitcombe and Tombs dispute and the Maritime Strike, with a focus on the contradictions between the press rhetoric, the framing of the strike, and the events of July-November 1890. Although the Maritime Strike ended a month before the 5 December General Election, the press struggled to consider the implications of unprecedented labour organisation and the rise of the Liberals. Chapter four examines the Liberals' emergence, situates organised labour within the political environment, and assesses newspapers' limited consideration of labour politics just weeks after the largest strike in New Zealand's history dominated the headlines. 


\section{Chapter One: New Zealand's Economy and Society, An Overview 1850-1890}

\section{The Colonial Economy, 1850 to 1890 :}

On the back of Governor George Grey's land purchases in the 1840s, New Zealand entered a period of steady growth and developing prosperity. A series of land deals between 1845 and 1853 netted the Crown over 32 million acres, mostly in the South Island, encouraging a wave of pastoral expansion, and laying the 'foundations of a dominant European economy'. ${ }^{1}$ Emerging domestic markets that encompassed both Māori and Pākehā populations, and the booming economies of New South Wales and Victoria, offered New Zealand farmers considerable scope for profit. Fruit, vegetables, cheese, wool, grain, timber, and gum became major tradable commodities. Growing British demand stimulated export values, which rose from $£ 393,000$ to $£ 1.3$ million between 1853 and 1861 . Yet the balance of trade remained negative throughout the period as demand for imports soared. ' ${ }^{2}$ Boosters', a mix of retailers, merchants, farmers, and millers, helped transform emerging towns into commercial centres, by establishing regular auction sales and mobilising resources for land improvement. ${ }^{3}$ Urban development also stimulated the financial services sector. Total bank deposits doubled from $£ 343,000$ to $£ 883,000$ in the four years from 1857 to 1861, and the Bank of Otago and Bank of New Zealand emerged as rivals to the previously dominant Union Bank of Australia. ${ }^{4}$

The 1860s gold rushes fundamentally changed the New Zealand economy. Gold was discovered in the Coromandel in 1852, and in 1857, the first major rush occurred

\footnotetext{
${ }^{1}$ W.J. Gardner, 'A Colonial Economy', in Geoffrey W. Rice (ed.) The Oxford History of New Zealand, Auckland: Oxford University Press, 1981, $2^{\text {nd }}$ edition, 1992, p.61.

${ }^{2}$ Muriel F. Lloyd Prichard, An Economic History of New Zealand to 1939, Auckland: Collins, 1970, pp.77-83.

3 Jim McAloon, 'The New Zealand Economy, 1792 - 1914', in Giselle Byrnes (ed.), The New Oxford History of New Zealand, Melbourne: Oxford University Press, 2009, p.206.

${ }^{4}$ Lloyd Prichard, An Economic History of New Zealand, pp.85-87.
} 
in Nelson. However, the discovery of gold in Otago in May 1861 opened the floodgates. Within three years, the Otago goldfields' population increased from several hundred to $24,000 .^{5}$ At the height of the gold rush, more migrants arrived in the colony than any other period in New Zealand history. Between 1861 and 1865, 93,169 people arrived in the colony, lured by the promise of a booming economy. ${ }^{6}$ The rush transformed Dunedin into New Zealand's commercial capital, and a number of important companies - Hallenstein Bros, Ross and Glendining, DIC, James Speight and Co., Union Steam Ship Company - began during the decade. ${ }^{7}$ Auckland also prospered in the $1860 \mathrm{~s}$, benefiting from the New Zealand Wars; in the shortterm, merchants profited from the garrisoning of troops in the city, while the city's leading capitalists grew wealthy through land confiscations and their dominance of the Fox-Whitaker Government. ${ }^{8}$

The years between 1870 and 1890 were economically turbulent for New Zealand. Although gold remained a significant export in the 1870s, particularly from the West Coast and Coromandel fields, the booms of the previous decade were over. Of the $£ 21$ million of gold extracted in Otago during the 1860 s, only $£ 600,000$ was produced in $1869 .{ }^{9}$ Cash land sales fell from 691,174 acres in 1864 , to 199,309 in $1868 .{ }^{10}$ Trade was declining; exports fell from $£ 7.4$ million in 1865 to $£ 5.1$ million in 1870 , and imports shrank from $£ 10.2$ million to $£ 8.2$ million. As the economy slowed, immigration abated. From the highs of the first half of the decade, net migration

\footnotetext{
5 James Forrest, 'Otago During the Goldrushes', in R.F. Walters (ed.), Land and Society in New Zealand: Essays in Historical Geography, Wellington: A.H. \& A.W. Reed, 1965, pp.83-84.

${ }^{6}$ Thorns and Sedgwick, Understanding Aotearoa/New Zealand, p.38.

7 K.C. McDonald, City of Dunedin: A Century of Civic Enterprise, Dunedin: Dunedin City Corporation, 1965, pp.180-81.

${ }^{8}$ McAloon, 'The New Zealand Economy', in Byrnes (ed.), The New Oxford History of New Zealand, p.208.

${ }^{9}$ Olssen, A History of Otago, p.66.

${ }^{10}$ Lloyd Prichard, An Economic History of New Zealand, p.120.
} 
plummeted to just 20,536 between 1866 and $1870 .{ }^{11}$ Economic dissatisfaction led to a parliamentary vote that toppled the Stafford Government, and returned William Fox as Premier and Julius Vogel as Treasurer. Over the next decade, the Fox-Vogel Government implemented a programme of centralised economic development that used London finance to promote land settlement, build infrastructure, and subsidise large-scale immigration to bolster the labour force and settler population.

Under Vogel’s stewardship, colonial debt rose from $£ 7.3$ million to $£ 18.6$ million, but his plan revolutionised the economy. ${ }^{12}$ Net migration surged: 136,743 immigrants flooded into the colony between 1871 and $1880 .{ }^{13}$ By 1880 the Railways Department operated almost 1,200 miles of railway, mostly in the South Island. ${ }^{14}$ Connecting railways with the emerging steamship network further strengthened interior communications and transportation - between 1859 and 1879 the journey between Auckland and Dunedin was reduced from 15 to six days. ${ }^{15}$ Government acquisition of vast tracts of Māori land in the North Island precipitated a dramatic expansion in farming. At the same time, the South Island experienced a wheat boom - cereal acreages increased from 240,000 to 640,000 during the decade, and between 1871 and 1886, 9.5 million additional acres were fenced. ${ }^{16}$ The resurgent economy boosted trade; by 1880 the value of exports had doubled to just over $£ 10$ million. $^{17}$

The frenetic speculation of the 1870 s came to a crashing halt in 1878 , following the collapse of the City of Glasgow Bank. Although British malpractice caused the failure, the bank blamed its losses on 'dubious colonial investments', and London

\footnotetext{
${ }^{11}$ Thorns and Sedgwick, Understanding Aotearoa/New Zealand, pp.38, 65-66.

12 Lloyd Prichard, An Economic History of New Zealand, p.131.

${ }^{13}$ Thorns and Sedgwick, Understanding Aotearoa/New Zealand, p.38.

${ }^{14}$ Neill Atkinson, Trainland: How Railways Made New Zealand, Auckland: Random House, 2007, p.38.

${ }^{15}$ Michael King, The Penguin History of New Zealand, Auckland: Penguin, 2003, p.232.

${ }^{16}$ G.R. Hawke, The Making of New Zealand: An Economic History, Cambridge: Cambridge University Press, 1985, pp.32-35.

${ }^{17}$ Thorns and Sedgwick, Understanding Aotearoa/New Zealand, p.65.
} 
investors lost confidence in New Zealand. ${ }^{18}$ Banks withdrew $£ 1.5$ million of credit within a year, leaving borrowers overcommitted. ${ }^{19}$ Over the next decade there were 11,444 bankruptcies - nearly ten per cent of the Pākehā adult male population. ${ }^{20}$ To succeed, Vogel's plan required healthy export prices and steady growth, yet the banking crisis was compounded by a series of bad harvests, and a worldwide slump in commodity prices that would persist until $1895 .^{21}$ Between 1888 and 1890 the colony experienced net emigration as workers sought security in prosperous New South Wales and Victoria. The 'Long Depression' had reached New Zealand.

The impact of the prolonged global recession on the New Zealand economy was variable, rather than universally bleak. Canterbury and Otago suffered first as their economies were sensitive to fluctuating commodity prices, while Auckland, where wool and wheat were less important, enjoyed growth until 1886. In the southern North Island, growth slowed but the region did not experience the dramatic exodus that afflicted the South Island. ${ }^{22}$ Unemployment became an urgent concern, and the Atkinson Government appointed a Royal Commission to examine the problem in 1883, but ignored its recommendations to lower interest rates for farmers, foster local industries, and implement agricultural labour schemes. ${ }^{23}$ Seven years later, Sir Harry Atkinson remarked, 'two men are in fact competing for one man's work' ${ }^{24}$ However, technological improvements offered hope of invigorating the sluggish economy. In 1882, the Dunedin, equipped with a new compression refrigeration hold, carried the

\footnotetext{
${ }^{18}$ McAloon, 'The New Zealand Economy', in Byrnes (ed.), The New Oxford History of New Zealand, pp.211-12.

${ }^{19}$ Keith Sinclair and W.F. Mandle, Open Account: A History of the Bank of New South Wales in New Zealand, 1861-1961, Wellington: Whitcombe and Tombs, 1961, p.87.

${ }^{20}$ James Belich, Replenishing the Earth: The Settler Revolution and the Rise of the Anglo-World, New York and Oxford: Oxford University Press, 2009, p.199.

${ }^{21}$ Merrett, 'A Reappraisal of the 1890 Maritime Strike', p.4.

22 James Belich, Paradise Reforged: A History of the New Zealanders from the 1880s to the Year 2000, Auckland: Allen Lane, 2001, p.35.

${ }^{23}$ W.B. Sutch, The Quest for Security in New Zealand, New York and Wellington: Oxford University Press, 1966, p.62.

24 'Financial Statement Made in Committee of Supply, 25 June, 1890', AJHR, 1890, B-6, p.19.
} 
first cargo of frozen meat from Port Chalmers to London. Before long, farmers would regularly export agricultural produce to metropolitan markets, alleviating the colony's economic reliance on wool. ${ }^{25}$ Despite the pronounced slump at the end of the decade, in the long-term workers benefited from economic growth. Although real GDP per capita fell slightly during the 1870 s and 1880 s, real wages rose 1.64 per cent annually over the same period. ${ }^{26}$ Amid the prevailing economic gloom of the 1880 s, 1889 was a period of relative prosperity, prompting a wave of employment and unionisation.

\section{Early New Zealand Trade Unionism:}

Economic fluctuations disrupted early attempts to entrench trade unionism in New Zealand. Trade unionists successfully stood out for the eight-hour working day in Wellington (1841) and Dunedin (1849), yet labour organisation proceeded gradually. ${ }^{27}$ Waves of unionisation occurred during economic 'booms', but these nascent organisations typically collapsed during 'busts'. Growing prosperity and the Vogelian influx of former British trade unionists in the 1870s stimulated a wave of unionisation. Between 1872 and 1875, ten unions were formed in both Canterbury and Dunedin, while six were established in Auckland and Wellington. ${ }^{28}$ Communication difficulties hampered colony-wide organisation, largely limiting trade unionism to the four main centres. ${ }^{29}$ As trade stagnated from 1879 and unemployment soared, many of the organisations established by early pioneers

\footnotetext{
${ }^{25}$ Keith Sinclair, A History of New Zealand, Auckland: Penguin, 1959, revised edition, 1988, p.167.

26 David Greasley and Les Oxley, 'Globalization and Real Wages in New Zealand 1873-1913', Explorations in Economic History, Vol. 41, no. 1, 2004, pp.26-47; David Greasley and Les Oxley, 'Refrigeration and Distribution: New Zealand Land Prices and Real Wages 1873-1939', Australian Economic History Review, Vol. 45, no. 1, March 2005, p.24.

27 James Thorn, The Formation and Development of Trades Unionism in Canterbury, Wellington: Standard Press, 1950, p.4.

${ }^{28}$ J.B. Condliffe, New Zealand in the Making: A Study of Economic and Social Development, London: Allen and Unwin, 1930, $2^{\text {nd }}$ revised edition, 1959, p.176.

${ }^{29}$ H. Roth, 'Trade Unions', in John M. Howells, Noel S. Woods, and F.J.L. Young (eds.), Labour and Industrial Relations in New Zealand, Melbourne: Pittman Pacific Books, 1974, p.4.
} 
vanished. Unions began re-emerging in the early 1880 s, only to collapse as the depression deepened. Yet, as Herbert Roth argues, workers had reason for optimism:

Each wave [of unionisation] was stronger than the previous one and the intervals between them became shorter. As each tide receded in periods of intensified economic depression, it still left a larger number of unions standing than previously. ${ }^{30}$

Early trade unions limited membership to skilled workers. Union rules, regulations, and names were imported from Great Britain, along with the migrants who had brought their experience of trade unionism with them. Memberships of these 'craft' bodies remained small, rarely exceeding 50 members, as tradesmen were selected for their competence, sobriety, and health. Furthermore, entrance fees and subscriptions were high to provide accident and unemployment benefits in the absence of state assistance. Early trade unions were all-encompassing institutions that protected traditional privileges and formed the locus of workers' social lives. ${ }^{31}$ Yet, craft unions cannot be considered conservative organisations. During the 1870 s, the 'fighting' bootmakers launched trade societies in all four main centres, 'consistently struck against [wage] reductions', and pioneered arguments for arbitration as a method of dispute resolution. ${ }^{32}$ An element of artisan radicalism permeated these societies, as famously championed by the Dunedin printer Samuel Lister in his weekly paper, the Otago Workman. Established in 1887, the paper espoused 'atheism, anticlericalism, republicanism and the values of brotherhood and democracy' while denouncing the greed of the wealthy. ${ }^{33}$

\footnotetext{
${ }^{30}$ H. Roth, Trade Unions in New Zealand, Wellington: A.H. \& A.W. Reed Ltd, 1973, p.10.

${ }^{31}$ ibid., pp.4-5.

32 J.D. Salmond, New Zealand Labour's Pioneering Days: the History of the Labour Movement in N.Z. from 1840 to 1894, Auckland: Forward Press, 1950, p.26.

${ }^{33}$ Erik Olssen, Building the New World: Work, Politics and Society in Caversham 1880s - 1920s, Auckland: Auckland University Press, 1995, pp.61-62.
} 


\section{The Rise of New Unionism, 1880-1890:}

In the late nineteenth century, labour organisation tactics evolved across North America, Europe, and Australasia as trade unionists adjusted to the new economic pressures of the Second Industrial Revolution. ${ }^{34}$ New economies of scale saw the factory replace the workshop. Falling wages, mechanisation, and an influx of unskilled workers marginalised older skills. Within this context, the emergence of new unionism is associated with two of the largest industrial disturbances in the British Empire: the London Dockers' Strike in 1889, and the Australasian Maritime Strike in 1890. Although the term 'new unionism' entered the vernacular concurrent with these strikes, the movement began two decades earlier. ${ }^{35}$ The legal recognition of the right to organise, beginning with the 1871 Trades Union Act in Britain and followed by similar legislation in New South Wales (1876 and 1881), New Zealand (1878), Victoria (1884), and Queensland (1885), fundamentally changed trade unionism, allowing labour organisations to develop beyond mutual benefit societies. ${ }^{36}$ In the years following beneficial legislation, semi-skilled and unskilled Australasian workers began coalescing into large federations. Trades and Labour Councils (TLCs) - bodies where delegates from all trades discussed common goals - first emerged in Sydney in 1871, Auckland in 1876, Melbourne in 1879, Adelaide in 1884, and

\footnotetext{
${ }^{34}$ For details of the global strike wave that accompanied changing patterns in labour organisation between 1886-1894 see Leopold Haimson and Charles Tilly (eds.), Strikes, Wars and Revolutions in an International Perspective: Strike Waves in the Late Nineteenth and Early Twentieth Centuries, Cambridge: Cambridge University Press, 1989; Neville Kirk, Labour and Society in Britain and the USA. Volume 2: Challenge and Accommodation, 1850-1939, Aldershot: Scolar Press, 1994, pp.97105, 115-35.

${ }^{35}$ Ray Markey notes that British usage of the term 'new unionism' emerged in 1890. The earliest Australian references occurred during the 1891 New South Wales Royal Commission on Strikes. In New Zealand, newspapers began using the term in late 1891. Ray Markey, 'New Unionism in Australia, 1880-1900', Labor History, no. 48, May 1985, p.17; Star, 16 July 1891, p.4.

${ }^{36}$ A.E.P Duffy, 'New Unionism in Britain, 1889-1890: A Reappraisal', The Economic History Review, Vol. 14, no. 2, 1961, pp.308-09.
} 
Christchurch in 1889, and five inter-colonial labour congresses were held between 1879 and $1890 .^{37}$

Labour historians have debated the precise definition, conceptual distinctiveness, and specific historical emergence of new unionism. ${ }^{38}$ Nevertheless, several fundamental principles are generally recognised. The important features of the new unions were their mass character and foundation of semi-skilled and unskilled labour, centralised leadership structure, and their intention to use industrial action to improve working conditions and wages. Broadly, new unions transcended the narrow focus on mutual benefits that defined smaller craft organisations. Mass organisation altered workers' self-perception, encouraging class consciousness. New unionism opened up a 'wider community of interest' that extended beyond craft and colonial boundaries. ${ }^{39}$ Aided by the telegraph and the newspaper, new unionism assumed an international dimension as workers, ideas, and finances flowed between emerging labour federations across the globe.

Australian labour organisers laid the foundations for new unionism in New Zealand in the $1880 \mathrm{~s}$. Motivated both by solidarity and the threatening ease of intercolonial labour mobility, Australian organisers travelled across New Zealand spreading unionism to unorganised workers. These early efforts targeted maritime and export industries, the locus of New Zealand labour agitation in the nineteenth and twentieth centuries. Ports were 'nodal points' through which migrants, money, and ideas entered and exited the colony - the basis of its survival, and the breeding

\footnotetext{
${ }^{37}$ Melanie Nolan, Kin, Christchurch: Canterbury University Press, 2005, p.58.

38 In particular, see Duffy 'New Unionism in Britain', pp.306-19; Eric Hobsbawm, 'The 'New Unionism' Reconsidered', in Wolfgang J. Mommsen and Hans-Gerhard Husung (eds.), The Development of Trade Unionism in Great Britain and Germany 1880-1914, London: George Allen and Unwin, 1985, pp.13-31; Richard Hyman, 'Mass Organization and Militancy in Britain: Contrasts and Continuities', in Mommsen and Husung (eds.), The Development of Trade Unionism in Great Britain and Germany 1880-1914, pp.250-65; Kirk, Labour and Society in Britain and the USA. Volume 2, pp.98-105; Markey, 'New Unionism in Australia', pp.15-28.

39 James Bennett, 'Rats and Revolutionaries': The Labour Movement in Australia and New Zealand 1890-1940, Dunedin: University of Otago Press, 2004, p.34.
} 
ground for transnational labour organisation. ${ }^{40}$ When George Sangster of the Australian Federated Seamen's Union (FSU), toured New Zealand ports in 1880, no union existed. He left behind a Federated Seamen's Union of New Zealand with branches in Port Chalmers, Auckland, and Wellington. ${ }^{41}$ The foundation of the Seamen's Union marked the first notable unionisation of semi-skilled and unskilled workers. In 1886 the West Coast organiser John Lomas affiliated the Denniston Miners' Union, established in 1884, with the Victorian-based Amalgamated Miners' Association (AMA). The move strengthened trans-Tasman bonds forged during the 1885 Denniston strike, when AMA subscriptions allowed the miners to prevail over the Westport Colliery Company (WCC). ${ }^{42}$ In spite of his efforts, Amalgamated Shearer's Union (ASU) President William Spence failed to organise the New Zealand shearing sheds. His 1887 visit saw the formation of a short-lived branch of the ASU, led by another Australian, James Slattery. Slattery claimed a total membership of 2,300 in June 1887, yet runholders refused to employ organised men and the union collapsed within the year. ${ }^{43}$ In 1887 , a chapter of the American organisation, the Knights of Labour, began in Christchurch, followed by an Auckland branch in June $1889 .^{44}$

Once established, most New Zealand labour organisations quickly adopted the principles of new unionism. Total union membership expanded from under 1,000 in 1880 to over 2,500 in $1885 .^{45}$ Between 1885 and 1888 membership numbers

\footnotetext{
${ }^{40}$ Lex Heerma van Voss, "Nothing to Lose but a Harsh and Miserable Life Here on Earth": Dock Work as a Global Occupation, 1790-1970', in Jan Lucassen (ed.), Global Labour History: A State of the Art, Bern: Peter Lang, 2006, p.592.

${ }^{41}$ Neill Atkinson, 'Against the Tide: the Auckland Seamen's Union, 1880-1914', in Pat Walsh (ed.), Trade Unions, Work and Society, Palmerston North: Dunmore Press, 1994, p.75.

${ }^{42}$ Richardson, Coal, Class and Community, pp.34-35.

${ }^{43}$ John E. Martin, The Forgotten Worker: the Rural Wage Earner in Nineteenth-Century New Zealand, Wellington: Allen and Unwin, 1990, pp.182-84.

${ }^{44}$ Robert E. Weir, Knights Down Under: The Knights of Labour in New Zealand, Newcastle upon Tyne: Cambridge Scholars Publishing, 2009, pp.5-13.

${ }^{45}$ Roth, Trade Unions in New Zealand, pp.5-8.
} 
fluctuated, as the first wave of new unionism crumbled in the economic gloom of the 'black' 1880s. Emblematic of the changes within the labour movement were the dynamic full-time organisers who galvanised trade unionism with their crusading zeal. In 1887, recently elected FSU General Secretary John Millar, an educated and 'dashing...master mariner', devised an innovative solution to combat the wage cuts imposed by the Northern Steam Ship Company. ${ }^{46}$ Bankrolled by the Australian FSU, New Zealand seamen launched the co-operative Jubilee Steam Ship Company in a ruthless attack on Northern's business. After 13 months of intense competition Northern capitulated and re-engaged all union men, unable to sustain Millar's financial bloodletting. ${ }^{47}$ John Millar was not alone in his crusade to foster solidarity among New Zealand workers. Throughout 1889, John Lomas traversed New Zealand, relentlessly organising the colony's miners. By March 1890, the AMA boasted 12 New Zealand branches and 2,000 members. ${ }^{48}$ Twelve new unions, numbering 12,250 members were organised in 1889 , bringing the number of trade unions to 75 with a total membership close to 20,000 in early $1890 .^{49}$

\section{Representing Labour - An Overview of Trade Unions in the Late Nineteenth} Century Press:

Labour issues received varying local and colonial coverage in the late nineteenth century press. All six newspapers published daily news columns that featured UPA reports on the domestic labour movement, from the suggestively titled section in the

\footnotetext{
${ }^{46}$ Neill Atkinson, Crew Culture: New Zealand Seafarers Under Sail and Steam, Wellington: Te Papa Press, 2001, p.120.

47 Between September 1887 and October 1888, John Millar claimed that the Jubilee Company lost $£ 14,000$ while the Northern Company lost $£ 22,000$. Neill Atkinson, 'Auckland Seamen and their Union, 1880-1922', MA thesis, University of Auckland, 1990, pp.59-71.

${ }^{48}$ Salmond, New Zealand Labour's Pioneering Days, p.43.

${ }^{49}$ Determining the number of unionised workers in New Zealand in the late nineteenth century remains a problem for historians. Tony Simpson provides a useful summary of the conflicting figures historians have advanced (anywhere between 20,000 and 63,000), and argues that even the lowest estimates appear generous given the low rates of union membership until 1889. Simpson, 'The Holt Narrative and the Industrial Relations Agenda', p.147.
} 
New Zealand Herald ('The Labour Agitation'), to the Lyttelton Times' diplomatic rubric ('Work and Wages'). These columns featured synopses of union meetings and publicised future events. In the smaller, four page dailies, (Grey River Argus, Otago Daily Times, Evening Post), such columns were often the only source of published information on organised labour. ${ }^{50}$ However, the New Zealand Herald, the Lyttelton Times, and the Press (each eight pages) supplemented syndicated stories on organised labour with regular reports from local union and TLC meetings.

In addition to reporting on domestic trade unions, newspapers informed readers about the international labour movement. Daily 'labour' columns combined domestic news with reports on international strikes, disputes, and negotiations. For example, on 7 May, the Evening Post and Grey River Argus reported on the 'sweating scandal' and 'eight-hours demonstration' in London, strikes in Vienna, and donations to the Brisbane Labour Federation's strike fund. ${ }^{51}$ Furthermore, newspapers augmented global labour news with editorial analysis. The New Zealand Herald frequently published editorials summarising trends within the international labour movement. Despite the paper's aversion to labour federation, in February it noted that the international labour movement, although 'more powerful now than at any time it its history', had prudently eschewed violence, a development that promised future industrial harmony. ${ }^{52}$ Later in the year, the paper examined the history of American and European trade unionism. ${ }^{53}$ At the Lyttelton Times, William Pember Reeves published a series of articles on radical politics, later collected in a pamphlet entitled

\footnotetext{
${ }^{50}$ Commercial pressures restricted column space. Of the 36 columns in the Otago Daily Times, 23 were devoted to advertising, leaving 13 for news, editorials, and letters. In the Grey River Argus, the split was 20/28 in favour of advertising, with just 8 columns of news and editorials, while the Evening Post typically devoted 10 of its 36 columns to news and editorials, with the remaining 26 columns sold for advertising revenue.

${ }^{51}$ EP, 10 May 1890, p.2; Grey River Argus (GRA), 10 May 1890, p.2.

${ }^{52}$ New Zealand Herald (NZH), 11 February 1890, p.4.

${ }^{53} \mathrm{NZH}, 3$ May 1890, p.4.
} 
'Some Historical Articles on Communism and Socialism'. 54 The articles, published pseudonymously, appeared between April and June, and ranged from reflections on Plato's Republic to contemporary European socialism. Coverage in the Otago Daily Times was more expansive, with the paper running an extensive fortnightly labour column, 'The Outlook of the Industrial World'.

The breadth of newspapers' engagement with the international labour movement belies the post-war claim that Australasia existed in isolation from the Northern Hemisphere. In the 1950s, Bill Pearson's evocative assessment of the New Zealand character, 'Fretful Sleepers', assumed samizdat status as it circulated through networks of academics and artists. ${ }^{55}$ Before returning from London in 1952, Pearson depicted a society that existed in profound isolation, detached even from 'Home' (the United Kingdom). ${ }^{56}$ In 1961, Geoffrey Blainey's argument that the 'tyranny of distance' separating the Antipodes from the Old World fundamentally shaped the Australian colonies was heralded within the academy. ${ }^{57}$ Distance undeniably influenced the development of Australasian colonies, but by the $1880 \mathrm{~s}$ the communication of information and ideas had already compressed the geographical obstacles between the metropolis and the periphery. While London remained between one and three months journey from Australasia in 1890, newspapers reported on events in Great Britain and Europe days after they had occurred.

More recently, historians have embraced the notion that networks of ideas, information, and people linked Great Britain with its colonies, and connected the

\footnotetext{
${ }^{54}$ Pharos, Some Historical Articles on Communism and Socialism: Their Dreams, The Experiments, Their Aims, Their Influence, Christchurch: Lyttelton Times, 1890.

${ }^{55}$ Paul Millar, 'Introductory Note', in Russell Brown (ed.), Great New Zealand Argument: Ideas About Ourselves, Auckland: Activity Press, 2005, p.48.

${ }^{56}$ Bill Pearson, Fretful Sleepers and Other Essays, London: Heinemann Educational Books, 1974, pp.30-31.

${ }^{57}$ The book was awarded the 1966 Con Weickhardt Award for Australian literature. Geoffrey Blainey, The Tyranny of Distance: How Distance Shaped Australia's History, Sydney: Pan Macmillan, 1966, $2^{\text {nd }}$ edition, 2001.
} 
colonies in unique cultural conglomerations. In 1986, Eric Fry compiled a history examining the common strands in Australasia labour history, and a year later Keith Sinclair established an explicitly transnational agenda in Tasman Relations. ${ }^{58}$ Over the last ten years, the notion of a social, economic, and cultural 'Tasman world' has become a popular tool for historians considering Australasia and the Pacific beyond the national trope. ${ }^{59}$ James Belich posits that the nineteenth century Australasian colonies operated as an organic entity that was both vague and semi-tangible, but also real and influential. A 'constant ebb and flow' of people, money, and ideas traversed the Tasman Sea. Financiers, soldiers, sailors, shearers, and miners worked in a fluid Australasian labour market, while inhabitants of all seven colonies were united by their joint cultural status as 'neo-Britains' - outposts of a wider pan-British culture. ${ }^{60}$ By reporting and editorialising on events from across this broad community of interests, newspapers reflected and reinforced these frames of reference, situating the local labour movement within a cultural world that stretched beyond the colony's borders.

\section{The Historiography of 1890 :}

1890 was a landmark year in New Zealand political and industrial relations, yet it has been relatively neglected in labour historiography. While the strikes of 1912, 1913, and 1951 have all received considerable academic attention, fewer studies focus on

\footnotetext{
${ }^{58}$ Eric Fry (ed.), Common Cause: Essays in Australian and New Zealand Labour History, Sydney: Allen and Unwin, 1986; Keith Sinclair (ed.), Tasman Relations: New Zealand and Australia, 17881988, Auckland: Auckland University Press, 1987.

${ }^{59}$ See Raelene Frances and Melanie Nolan, 'Gender and the Trans-Tasman World of Labour: Transnational and Comparative Histories', Labour History, no. 95, pp.25-42. Philippa Mein Smith, Peter Hempenstall, and Shaun Goldfinch, Remaking the Tasman World, Christchurch: Canterbury University Press, 2009; Philippa Mein Smith, 'The Tasman World', in Byrnes (ed.), The New Oxford History of New Zealand, pp.297-319.

${ }^{60}$ Belich, Paradise Reforged, pp.46-47.
} 
the 1890 strike. $^{61}$ Associated with the rise of organised labour, party politics, and the beginning of 21 years of Liberal government - 'the end of the old world' - 1890 has been a convenient starting point for labour historians since William Pember Reeves celebrated the Liberals' achievements in The Long White Cloud and State Experiments in Australia and New Zealand. ${ }^{62}$ Yet, the characterisation of 1890 as the prelude to a 'new era' has seen labour historians overlook prior events, and as Erik Olssen argues, even 'the new social history...has been subverted here into a celebration of the Reevesian paradigm' ${ }^{63}$

Unlike more prominent episodes in New Zealand labour history, the best studies of the Maritime Strike remain unpublished. Ian Merrett's 1969 thesis is the most comprehensive examination of the strike. Merrett aimed to revise the 'gross misrepresentation' of the strike, as popularised by J.D. Salmond's thesis - the authoritative history of the subject for over 50 years. ${ }^{64}$ He rejected the traditional notion that the strike was a response to Australian workers' demands, viewing this interpretation as a repetition of contemporary conservative dogma. Instead, Merrett argues that both the Union Company and the Maritime Council were reluctantly

${ }^{61}$ John Crawford, 'Overt and Covert Military Involvement in the 1890 Maritime Strike and 1913 Waterfront Strike in New Zealand', Labour History, no. 60, May 1991, pp.66-83; W.J. Gardner, Prelude to Arbitration in 3 Movements: Ulster, South Australia, New Zealand 1890-1894, Christchurch: Caxton Press, 2009; Bruce Scates, 'Gender, Household, and Community Politics: The 1890 Maritime Strike in Australia and New Zealand', Labour History, no. 61, November 1991, pp.7087.

${ }^{62}$ Stevan Eldred-Grigg, New Zealand Working People, 1890-1990, Palmerston North: Dunmore Press, 1990, p.9; See also Bennett, 'Rats and Revolutionaries': The Labour Movement in Australia and New Zealand 1890-1940; John Martin, '1890: A Turning Point for Labour', in Pat Walsh (ed.), Pioneering New Zealand Labour History: Essays in Honour of Bert Roth, Palmerston North: Dunmore Press, 1994, pp.21-51; William Pember Reeves, State Experiments in Australia and New Zealand, London: Grant Richards, 1902; William Pember Reeves, The Long White Cloud, Christchurch: Golden Press, $1898,4^{\text {th }}$ edition, 1980.

${ }^{63}$ John E. Martin, 'Labor History in New Zealand', International Labor and Working-Class History, no. 49, Spring 1996, p.172; Erik Olssen, 'Where to From Here? Reflections on the Twentieth-Century Historiography of Nineteenth-Century New Zealand', New Zealand Journal of History (NZJH), Vol. 26, no. 1, April 1992, p.69.

${ }^{64}$ Merrett, 'A Reappraisal of the 1890 Maritime Strike', p.239; J.D. Salmond, 'The History of the New Zealand Labour Movement From the Settlement to the Conciliation and Arbitration Act 1894', MA thesis, University of Otago, 1924, pp.61-62. A condensed version of the thesis was published in 1954, entitled New Zealand Labour's Pioneering Days. 
drawn into an Australian dispute by their respective trans-Tasman affiliations, although the strike continued for practical and ideological reasons. For labour, failure to strike implied their acquiescence to the limitation of association, while capitalists sensed an opportunity to crush the growing trade unions. James Bennett's 1986 thesis locates the Maritime Strike within a triangular (Britain, Australia, and New Zealand) nexus of new unionism. ${ }^{65}$ He suggests that the 1889 London Dock Strike cemented the concept of 'combination' as an effective bargaining strategy, amongst an intercolonial labour force that maintained strong cultural and ideological bonds. More recently, W.J. Gardner located the Maritime Strike within another triangular axis the growing compulsory arbitration movement in the British Empire. His study emphasises the similarities between contemporary labour struggles in New Zealand, Ulster, and South Australia. ${ }^{66}$

Ian Merrett contends that employers considered trade unions desirable in $1890 .^{67}$ His assertion is surprising in a year marked by the intransigence of both labour and capital in industrial disputes. In his work on the coal mining industry, Len Richardson documents mine owners' determination to prevent unionised colliers entering the pits. ${ }^{68}$ John Martin discusses a similar antipathy to labour organisation amongst farmers and runholders. ${ }^{69}$ Gavin McLean, in his history of the Union Steam Ship Company, reaches a similar conclusion. He notes that the company directors insisted

\footnotetext{
65 James Bennett, 'The 1890 Maritime Strike and the Triangular Relationship Between Britain, Australia and New Zealand', MA thesis, University of Canterbury, 1986.

${ }^{66}$ Gardner, Prelude to Arbitration. In addition to the aforementioned theses, it should be noted that Peter Mitchell's 1948 thesis offers a thorough, if uncritical account of the labour struggles in 1890, while Neill Atkinson's research on the Auckland FSU provides valuable context, despite its cursory discussion of the Maritime Strike. Atkinson, 'Auckland Seamen and their Union', pp.75-79; Peter Alexander Mitchell, 'John Andrew Millar and the New Zealand Labour Movement', MA thesis, Victoria University of Wellington, 1948, pp.16-71.

${ }^{67}$ Merrett, A Reappraisal of the 1890 Maritime Strike', p.258.

${ }^{68}$ Len Richardson, Coal, Class and Community: The United Mineworkers of New Zealand, Auckland: Auckland University Press, 1995, pp.18-22.

${ }^{69}$ Martin, The Forgotten Worker, pp.169-96.
} 
on strict managerial control, an attitude that led to frequent clashes with unions. ${ }^{70}$ Although anti-union sentiments were pervasive, the politics of the wealthy cannot simply be described as an 'oligarchic brake' on social progress. Jim McAloon contends that property owners stood on both sides of debates concerning land, public expenditure, and political rights. ${ }^{71}$ Thorough analysis of newspaper coverage of labour issues in 1890 will clarify the debate, and offer a fuller understanding of the position of trade unions in New Zealand society.

Despite the limited discussion of the events of 1890, historians have long contested the years' significance for labour. W.J. Gardner contends that the year passed with a 'feeling of opportunity lost' for the creation of a new, balanced society. ${ }^{72}$ Conversely, John Martin argues that 1890 has been exaggerated as a 'benchmark year' dividing the 'dark ages' of economic and industrial injustice with a 'modern enlightened era' that began after the 1890 General Election. ${ }^{73}$ Like David Hamer, Martin contends that the Liberals' labour policies continued 20 years of industrial reform. ${ }^{74} \mathrm{Jim}$ McAloon and W.J. Gardner contest these attacks on the 'genuineness' of colonial democratic ideology, with McAloon arguing that the election, the first under the one-man, one-vote system instituted by the 1889 Representation Act Amendment Bill, saw a 'seismic shift' towards populism and democracy in New Zealand political culture. ${ }^{75}$

The debate fits within a wider discussion concerning the extent and causation of political change in the $1880 \mathrm{~s}$, between proponents of what John Angus described as

\footnotetext{
${ }^{70}$ Gavin McLean, The Southern Octopus: the Rise of a Shipping Empire, Wellington: New Zealand Ship and Marine Society, 1990, pp.43-45, 115.

${ }^{71} \mathrm{Jim}$ McAloon, No Idle Rich: the Wealthy in Canterbury and Otago, 1840-1914, Dunedin: University of Otago Press, 2002, pp.96-105.

${ }^{72}$ Gardner, Prelude to Arbitration, pp.123-24.

73 Martin, '1890: A Turning Point for Labour', in Walsh (ed.), Pioneering New Zealand Labour History, p.21.

${ }^{74}$ See Hamer, The New Zealand Liberals, p.23.

${ }^{75}$ McAloon, No Idle Rich, p.105; Gardner, Prelude to Arbitration, pp.119-124.
} 
the 'consensus' and 'conflict' interpretations of New Zealand history. ${ }^{76}$ Originated by William Pember Reeves and perpetuated by Keith Sinclair, the 'conflict' school stresses that the 1880 s depression fuelled class conflict and widened the divide between conservative and radical politicians. ${ }^{77}$ Their interpretation holds that class tensions were manifested in the rejection of the Atkinson Government in favour of the Liberals' promises of reform. In the late 1950s, a new interpretation arose, emphasising the relative absence of class tensions, the prevalence of social mobility, and the existence of a broad liberal consensus within late nineteenth century society. In this articulation of New Zealand history, stated most comprehensively by David Hamer in The New Zealand Liberals, the 1890 election displayed strong historical continuities rather than representing a profound shift in colonial political culture. ${ }^{78}$

While interpretations of the Liberals' rise to power remain contested, labour's role in the electoral process has been under-emphasised. The traditional interpretation of labour politics in 1890 stresses a dramatic shift in focus from the industrial to the political arena, following the collapse of the Maritime Strike. As Erik Olssen and Len Richardson argue, 'defeat on the industrial front was complete [after November 1890], but within months the unionists had thrust themselves firmly into the political arena. Previously trade union officials had been ambivalent in their attitude to politics' ${ }^{79}$ The assertion that the significance of the Maritime Strike lay in its failure,

\footnotetext{
${ }^{76}$ John H. Angus, 'City and Country, Change and Continuity: Electoral Politics and Society in Otago, 1877-1893', PhD Thesis, University of Otago, 1976, pp.7-9; Robert Chapman, 'Foreword', in Robert Chapman (ed.), Ends and Means in New Zealand Politics, Auckland: University of Auckland, 1961, pp.1-3.

Reeves, The Long White Cloud, pp.270-80; Sinclair, A History of New Zealand, pp.166-71; Keith Sinclair, 'The Significance of 'the Scarecrow Ministry', 1887-1891', in Robert Chapman and Keith Sinclair (eds.), Studies of a Small Democracy: Essays in Honour of Willis Airey, Auckland: Blackwood and Janet Paul, 1963, pp.102-26.

${ }^{78}$ Hamer, The New Zealand Liberals, pp.13-36; Martin, '1890: A Turning Point', in Walsh (ed.), Pioneering New Zealand Labour History, pp.21-51; W.H. Oliver, 'Reeves, Sinclair and the Social Pattern', in Peter Munz (ed.), The Feel of Truth: Essays in New Zealand and Pacific History, Wellington: A.H. \& A.W. Reed, 1969, pp.163-78.

${ }^{79}$ Erik Olssen and Len Richardson, 'The New Zealand Labour Movement, 1880 - 1920', in Fry (ed.), Common Cause, p.4.
} 
particularly given the Liberals' progressive legislative agenda, is uncontroversial. Yet, examining 1890 as an isolated 'turning point' ignores existing research on labour's political agitation in the 1870 s and 1880 s. Nevertheless, defeat clearly forced trade unions to reconsider any lingering ambivalence regarding Parliamentary representation, and commit to political, as well as industrial activism. 


\section{Chapter Two: 'The Trade Unions are on their trial': Precursors to the Maritime Strike in New Zealand}

The 1889 London Dock Strike, indelibly linked with the rise of new unionism, signalled the maturity of the movement in Great Britain, and captivated the Englishspeaking world. New Zealand newspapers were no exception, lamenting the plight of London's working poor while glossing over the unprecedented federation that allowed the dockers to collectively demand wage increases. The formation of New Zealand's first labour federation, the Maritime Council, weeks after the strike ended, similarly elicited little press attention. While the rise of domestic trade unions was no secret, the phenomenon was largely ignored in early 1890. However, newspapers' complacent attitude towards the rising labour movement quickly faded as the Maritime Council assumed a prominent role in disputes affecting vital industries shipping, mining, and the railways. Contests over wages and working conditions, the staples of industrial ferment, were augmented by new demands to regulate interactions between labour and management, compounding establishment unease with the newly assertive labour movement. New Zealanders sympathised with workers' concerns, as the 1889-1890 'sweating' crisis revealed, yet as the impact of labour federation became apparent so did reservations about trade unions' expanding influence. Newspapers continued to support workers struggling against iniquitous employers, yet insisted that trade unions display the utmost moderation in their actions, ignoring the vast political and economic imbalances that allowed employers to dismiss their concerns. As labour grew weary of the handicaps imposed by the hollow doctrine of moderation, the press sought to marginalise the resurgent labour movement, striving to convince readers that the colonial consensus remained intact. 


\section{Common Cause? Australasian Reactions to the 1889 London Dock Strike:}

The London Dock Strike began on 12 August 1889 when the impoverished dock labourers, frustrated by their implacable employers, sought to increase their hourly wages from 5 to $6 \mathrm{~d}$. Within a week 10,000 men were out, a figure that exploded to 150,000 by 30 August. Despite the unprecedented public demonstrations, time and hunger imperilled the dockers' cause. Daily relief costs ran to $£ 1,250$, and the Dock Directors intended to starve the workers into submission. When negotiations failed, the strike leaders circulated a general strike manifesto. ${ }^{1}$ The threat diminished public sympathy for the dockers, and was quickly withdrawn. ${ }^{2}$ On the verge of defeat, news of Australian support rescued the strike - on the day of the manifesto's publication, trade unions telegraphed $£ 700$ to London. The donation, and promise of further assistance renewed enthusiasm at the pickets as the strike spread across London. By 14 September, Australian aid stood at $£ 36,164$, three quarters of the total strike relief fund. ${ }^{3}$ The dockers now had the upper hand, and forced their employers to negotiate a settlement. The Mansion House Agreement, signed on 16 September, ended the strike - the dock companies re-employed the union men, and offered improved terms from 4 November 1889.

Sympathetic Australian newspaper coverage of the London Dock Strike stimulated public generosity. Yet P.F. Donovan's claim that Australian newspapers uncritically followed the sympathetic agenda set by the London dailies is erroneous. ${ }^{4}$ While world news could be published within two days, high telegram rates limited

\footnotetext{
${ }^{1}$ The Times, 31 August 1889, p.5.

${ }^{2}$ The Times, 2 September 1889 , p.4.

3 P.F. Donovan, 'Australia and the Great London Dock Strike: 1889', Labour History, no. 23, November 1972, pp.17-22.

${ }^{4}$ ibid., pp.19-20.
} 
newspapers to printing brief summaries. ${ }^{5}$ Editorials arrived with complete editions of British newspapers, which took around a month to reach Sydney, precluding Australian (and New Zealand) periodicals from closely following London opinions. The suggestion that the dockers received widespread acclamation in the British press is also misleading. Aside from the 'radical' newspapers (Pall Mall Gazette, Star, Lloyd's News), the strike received no consistent support in the mainstream press. ${ }^{6}$ The Times, usually described as the dockers' ally, became critical of 'professional agitators' as the strike continued into September. ${ }^{7}$ Its views resonated with those of the conservative London Standard, which registered concern at the 'sinister liberality' of the 'aggressive outsiders' from the Antipodes. ${ }^{8}$

Nevertheless, from 29 August, Australian newspapers began reporting extensively on the strike. Aside from framing the news in a manner sympathetic to the dockers, Australian newspapers encouraged readers to contribute to the strike relief fund. A Melbourne Age editorial on 29 August inspired readers to establish a relief fund and send the paper money for transmission to London. ${ }^{9}$ With 80,000 readers and strong connections with Trades Hall, the Age led Victorians to donate more money per capita than any other Australian colony. ${ }^{10}$ In Sydney, the liberal Daily Telegraph pressured leading citizens to contribute to the cause and rebuked those who hesitated. ${ }^{11}$ Even conservative papers like the Melbourne Argus and Sydney Morning Herald encouraged charity. ${ }^{12}$ Inspired by sympathetic reporting, public meetings held

\footnotetext{
5 Simon J. Potter, News and the British World: The Emergence of an Imperial Press System, 18761922, Oxford and New York: Clarendon Press, 2003, p.29.

${ }^{6}$ Walker, 'Media and Money', pp.43-44.

${ }^{7}$ The Times, 2 September 1889, p.4; The Times, 9 September 1889, p.4.

${ }^{8}$ Standard, 9 September 1889, no page, in Walker, 'Media and Money', p.4.

${ }^{9}$ Age, 29 August 1889, p.4.

${ }^{10}$ Queensland gave 1.3d. per head (£2,135.9 total); New South Wales gave 1.8d. (£8,386.5); South Australia gave 2.3d. (£3,073.9); Victoria gave 4.9d. (£22,569.5); Donovan, 'Australia and the Great London Dock Strike', p.22.

${ }^{11}$ Sydney Daily Telegraph, 6 September 1889, no page, in Donovan, 'Australia and the Great London Dock Strike', p.24.

${ }^{12}$ Sydney Morning Herald, 9 September 1889, p.4; Melbourne Argus, 6 September 1889, p.4.
} 
across Australia established generous relief funds that rescued the strike from the brink of collapse.

New Zealand newspapers devoted considerably less column space to the London strike than their Australian counterparts. UPA membership gave editors access to Reuter's foreign news cables (via the Melbourne Age-Argus telegraph service), which provided all of the news reported on the strike in New Zealand and Australia. ${ }^{13}$ The strike was first covered by the Evening Post on 20 August, and picked up colonywide on 22 August. As in Australia, coverage was brief until 29 August, by which point most newspapers allocated a designated column to the strike. Editors tended to emphasise New Zealand connections to the strike - particularly the plight of the refrigerated vessels Fifeshire and Kaikoura. With ships unable to unload their cargoes or take on coal to maintain refrigeration, it was feared that 35,000 mutton carcasses would rot. ${ }^{14}$

Although New Zealand newspapers sympathised with the London dockers, they eagerly compared British social ills with apparent colonial class harmony. ${ }^{15}$ The Otago Daily Times hoped the Dock Strike would expose the plight of the urban poor and stressed the necessity of 'taking some steps to mitigate the condition of the millions in Great Britain who drag out a precarious existence'. ${ }^{16}$ Similarly, the Lyttelton Times evoked the hardships suffered by London wharf labourers as they unloaded New Zealand produce. ${ }^{17}$ The Grey River Argus lauded the strike as 'one of

\footnotetext{
${ }_{13}^{13}$ Potter, News and the British World, pp.90-91.

${ }^{14}$ ODT, 29 August 1889, p.2.

${ }^{15}$ James Belich describes the concept of 'progress' as one of New Zealand's 'formal myths of settlement'. In New Zealand, 'progress' entailed avoiding the negative consequences of economic advancement, specifically 'a loss of rural virtue; the vices of industrialism; and class tension and conflict'. This idea of progress also had a strongly individualistic component. Early New Zealanders believed that the colony was a land where working people could arrive from the Old World, serve as labourers or servants while they saved money, and eventually purchase a small business or property and become part of the middle class. See Paradise Reforged, pp.21-22.

${ }^{16} O D T, 30$ August 1889, p.2.

${ }^{17} L T, 19$ September 1889 , p.4.
} 
the grandest object lessons of the century in educating the working class regarding their rights and the means of securing them' ${ }^{18}$ These editorials were not only instructive, but also cautionary. On 30 August, the Evening Post warned New Zealanders to 'guard against the development of weak features in the social development of the Mother Country'. ${ }^{19}$ The incredible commercial disruption and social upheaval produced by the Dock Strike was juxtaposed with the relative industrial amity in New Zealand simultaneously as an act of self-congratulation and of warning. While the Otago Daily Times praised the dockers' cause, it remained wary of federated labour, adding the caveat that the future demands of workingmen 'may not always be just'. 20 The desire to avoid similar disruption in the colony was clear - a path that required moderation from both labour and capital.

Unlike Australia, widespread press sympathy did not translate into financial generosity towards the London dockers. New Zealanders contributed a paltry $£ 400$ to the relief fund, just one tenth of a shilling per capita. ${ }^{21}$ Such miserliness is partially explained by New Zealand newspapers' avoidance of the fundraising role taken by their Australian counterparts. ${ }^{22}$ While the Sydney Daily Telegraph publicly humiliated stingy capitalists, the New Zealand Herald cautioned workers against supporting the London strike. The paper questioned the dockers' motives, noting that 25s. per week was 'not a bad wage for the rudest kind of unskilled labour'. If money were telegraphed to London, the Herald believed it should be given to the men

\footnotetext{
${ }^{18}$ GRA, 5 September 1889, p.2.

${ }^{19} E P, 30$ August 1889, p.2.

${ }^{20} O D T, 27$ September 1889, p.2.

${ }^{21}$ Donovan, 'Australia and the Great London Dock Strike', p.22.

${ }^{22}$ Sir Robert Stout later reflected that the paucity of donations to the London dockers revealed New Zealanders' lack of empathy. 'I addressed two large meetings, one in Wellington in favour of the [London] strikers as I believed they had been unjustly treated. I think all or mostly all of those afterwards termed the friends of Labour did not take up the position I took - they did nothing'. Sir Robert Stout to J.D. Salmond, 22 October 1923, Herbert Otto Roth Papers, MS-Papers 94-106-29/02, Alexander Turnbull Library (ATL).
} 
prevented from working by the striking unionists. ${ }^{23}$ Commenting on the unprecedented display of inter-colonial beneficence, the Otago Daily Times cryptically noted that Australian generosity was 'significant...[but] its precise significance is not so clear'. ${ }^{24}$

Within a month of the London dockers' victory, the new union movement consolidated its position in New Zealand. After a three-day conference in Dunedin, beginning on 26 October, the Maritime Labour Council of New Zealand (Maritime Council) was established on 28 October. Seeking to redress the lack of solidarity within New Zealand labour circles, John Millar gathered representatives from the seamen's, wharf labourers', and miners' unions. Those present sought to form a federation with the cumulative power to 'enforce the carrying out of legitimate and necessary reforms where a single Union might find the task beyond its individual strength'. ${ }^{25}$ Modelled on the Australian Maritime Council (1885), the body was New Zealand's first colony-wide labour organisation that transcended trade divisions. John Millar was elected Secretary, with D.P. Fisher (Wellington TLC President) as President, and John Lomas as Treasurer. Initially, membership of the Maritime Council was limited to maritime or cognate trades (including miners), and at its inception it had 3,850 members (reported as 8,000$).{ }^{26}$

Coverage of the Maritime Council's formation was sparse as journalists were excluded from the inaugural meetings. ${ }^{27}$ The Evening Post and Press only published brief reports on 26 October, while the Grey River Argus and New Zealand Herald

\footnotetext{
${ }^{23}$ By contrast, Auckland dockers earned 1s.3d. an hour. NZH, 6 September 1889, p.4; Bert Roth, Wharfie: "From Hand Barrows to Straddles" Unionism on the Auckland Waterfront, Auckland: The Auckland Branch, New Zealand Waterfront Workers Union, 1993, p.18.

${ }^{24}$ ODT, 2 September 1889, p.2.

25 'Proposed Basis of the Maritime Council', 1889, Roth Papers, MS-Papers 94-106-29/04, ATL.

26 'Notes on the Actual and Claimed Membership of the Maritime Council', 1889-1890, Roth Papers, MS-Papers 94-106-29/04, ATL.

${ }^{27}$ I have been unable to determine why journalists were excluded from the meeting, but the embargo indicates a certain distrust of newspapers within the labour community.
} 
ignored the event altogether. ${ }^{28}$ Coverage in the Lyttelton Times was more extensive, with a story on 28 October summarising the Maritime Council's Constitution. ${ }^{29}$ In the only editorial on the Maritime Council, the Otago Daily Times regarded the development with the same caution as it had the London Dock Strike. The new federation was judged to possess a 'great deal more strength' than its individual components, and the paper advised Millar to exercise his authority wisely. Ostensibly the Otago Daily Times supported the Council, yet qualified that sentiment by concluding, 'there is such a thing...as the tyranny of labour'. 30

At the end of 1889, newspapers were divided over trade unionism. All paid lip service to the necessity of labour organisation, yet the necessity of industrial action was contested. Liberal newspapers believed that trade unions were necessary to curb the excesses of industrial capitalism that had produced the London strike. Thus, the domestic rise of trade unionism, a decade-long process by 1890 , was perceived as an opportunity for moderate social reform. By contrast, conservative newspapers warned readers that labour federation had dangerous consequences. On the eve of 1890 , the runholders, merchants, industrialists, financiers, and professionals that constituted New Zealand's capitalist class regarded the nascent wave of unionisation with apprehension. For all their successes, trade unions were on their guard. Unemployment remained high, and the majority of the workforce was unorganised and desperate for jobs - there was no room for error. ${ }^{31}$

\footnotetext{
${ }^{28}$ EP, 26 October 1889, p.2; Christchurch Press, 26 October 1889, p.5.

${ }^{29} L T, 26$ October 1889 , p.5; LT, 28 October 1889, p.5.

${ }^{30}$ ODT, 28 October 1889 , p. 2 .

${ }^{31}$ In 1890 trade union members accounted for just 9.6 per cent of the paid workforce; Eldred-Grigg, New Zealand Working People, p.21.
} 


\section{Trouble at Home - The Sweating Commission:}

The opening of the Royal Commission on Sweating in Dunedin on 9 February 1890 encouraged trade unionists to believe that agitation had started to pay dividends. An official inquiry into private enterprise on the suspicion that it caused social-ills represented a novel exercise of state power. ${ }^{32}$ Public concern regarding 'sweating' sub-contracting piecework (typically in the garment industry) to women and children at starvation wages - had existed since the passage of the Employment of Females in Workrooms and Factories Act 1873, but reached a crescendo in October 1888 following a fiery address by the Dunedin social reformer, Reverend Rutherford Waddell. ${ }^{33}$ In his sermon, 'The Sin of Cheapness', Waddell argued that the desire for cheap merchandise had forced wages below a subsistence level. ${ }^{34}$ Reporting on the sermon, the Otago Daily Times claimed, 'the system prevails in Dunedin even to a worse extent than it does at Home' ${ }^{35}$ In January 1889, Otago Daily Times journalist Silas Spragg investigated 'The Sweating System in Dunedin'. His articles, published between 22 and 28 January, elaborately detailed the excessive hours and brutal conditions suffered by seamstresses and factory workers. ${ }^{36}$ His conclusion matched Waddell's - sweating was an urgent social problem produced by 'excessive competition' for manufacturing contracts. On 7 June 1889, former Premier Sir Robert Stout addressed the Anti-Sweating Committee and called for the government to appoint a Royal Commission to consider the matter. ${ }^{37}$ Four days later, the Tailoresses' Union was formed in Dunedin. Public outrage at the existence of

\footnotetext{
${ }^{32}$ Gardner, Prelude to Arbitration, p.112.

33 John E. Martin 'English Models and Antipodean Conditions: the Origins and Development of Protective Factory Legislation in New Zealand', Labour History, no. 73, November 1997, pp.55-60.

${ }^{34}$ Ian Breward, 'Waddell, Rutherford 1850-1852? - 1932', Dictionary of New Zealand Biography; available from http://www.dnzb.govt.nz/dnzb/alt_essayBody.asp?essayID=2W1; accessed 25 April 2010.

${ }^{35}$ ODT, 20 October 1888, p.3.

${ }^{36}$ J.T. Paul, The Otago Daily Times Diamond Jubilee, 1861-1921: Sixty Years of Achievement. The Press of Otago and Southland, Dunedin: Otago Daily Times and Witness Newspapers Co., 1924, p.31.

${ }^{37}$ Salmond, New Zealand Labour's Pioneering Days, p.63.
} 
Dickensian 'workhouses' in New Zealand proved influential - on 28 January 1890 Governor Onslow authorised an official inquiry.

Although the Sweating Commission had a colony-wide focus, newspaper coverage of the inquiry was typically parochial. As a rule, newspapers provided extensive summaries of testimony before the Commission when it sat in their region, and largely ignored its proceedings elsewhere. Surprisingly, the Otago Daily Times' coverage of the Dunedin hearings (10-28 February) was sparse, particularly in light of the newspaper's efforts to expose industrial exploitation. Throughout the Dunedin session, the newspaper limited its coverage of the Commission to brief tri-weekly summaries, without editorial comment. The Daily Times had four pages, yet space constraints did not prevent the similarly sized Evening Post from publishing daily updates on the Dunedin sessions. Like the Otago Daily Times, the Press and Lyttelton Times reported on events in Dunedin sporadically. The Grey River Argus, published from a town outside the Commission's purview, covered the opening day's proceedings in Dunedin, then ignored the inquiry until its Wellington hearings began in April.

When the Sweating Commission sat in Christchurch and Auckland, local newspapers were more attentive than the Otago Daily Times had been in Dunedin. In Christchurch, both the Press and Lyttelton Times reported on the testimony heard before the Commission in comprehensive daily stories, but did not publish editorial comment. The New Zealand Herald also ran thorough daily reports on the Commission, but used the opportunity to attack the inquiry. Prefacing a report on 29 March, the Herald remarked that the day's testimony had 'incited little interest'. ${ }^{38}$ Displeasure with the Sweating Commission was stated more directly by the Evening Post. In an editorial published a week before the Commission sat in Wellington, the

${ }^{38}$ NZH, 29 March 1890, p.6. 
paper decried the investigation as a 'farcical comedy', its purpose contradicted by the absence of 'sweating' in the colony. For the Post, the Commission's title evoked 'visions of ill-fed, over-worked, under-paid, and intensely miserable work-people', but revealed little more than a few cases of 'unduly long hours'. Concerned with the expense of the Commission, and the prospect of needless government intervention, the Post called for an immediate end to the 'absurdity'. ${ }^{39}$

Despite the Post's bluster, the mandate of the Sweating Commission was not to determine the existence of 'sweating', but to broadly investigate employment conditions. ${ }^{40}$ Yet, when the Commission released its report, newspapers disregarded the inquiry's wider purpose, framing it as a repudiation of rumours that 'old-world' injustices occurred in New Zealand. The Commission found no evidence of 'sweating', but recommended an amended Factories Act to prevent employers exploiting legislative loopholes, a minimum factory working age of 14, and limits on the employment of workers under 18. A dissenting opinion, written by three labour representatives on the Commission, argued that if 'sweating' was defined broadly as the existence of overcrowded workshops, long working hours, and subsistence wages, it occurred to a 'very large extent' ${ }^{41}$ While the Otago Daily Times admitted legislative amendments were required, it disregarded the dissenters' reservations as purely semantic. $^{42}$ The Herald took a similar position. Rather than expanding the civil

\footnotetext{
${ }^{39} E P, 10$ April 1890, p.2.

${ }^{40}$ The mandate of the Sweating Commission was to 'inquire into the mode and terms in and on which persons are employed...and upon the relations generally of employer and employed, and the best machinery for determining matters and questions arising between them and relating to their respective interests'. See 'Report of the Royal Commission Appointed to Inquire into Certain Relations Between the Employers of Certain Kinds of Labour and the Persons Employed Therin', AJHR, 1890, H-5, p.i. Several newspapers reported on the Commission's broader focus. EP, 10 February 1890, p.3; LT, 11 February 1890, p.5; Press, 10 February 1890, p.6.

${ }^{41}$ Reverend Rutherford Waddell, D.P. Fisher, and Colin Allen wrote the dissenting opinion. AJHR, 1890, H-5, p.vi.

${ }^{42}$ ODT, 28 May 1890, p.2.
} 
service to monitor compliance with labour legislation, it favoured a cheaper alternative - conferring the existing factory inspectors with additional powers. ${ }^{43}$

Although the Sweating Commission failed to improve working environments in the short-term, it revealed much about the socially accepted role for trade unions in 1890. Witnesses from diverse backgrounds emphasised the advantages of moderate, mutual benefit societies, rather than assertive 'new' unions. Between February and April, many informants noted that unionisation had improved their industries. Conversely, witnesses remarked on the absence of workers' organisation in industries where conditions remained poor. Within the Commission, the almost exclusive focus on non-confrontational tactics indicated self-censorship. On several occasions the Commissioners were notified that witnesses had declined to testify for fear of being blacklisted - confessions that revealed existing animosities between unions and employers. ${ }^{44}$ When newspapers depicted trade unions positively, it was usually to emphasise their value as organisations for the maintenance of industrial harmony. The notion that 'moderate' unions could protect workers without government intervention was fanciful, but commonly asserted by newspaper editors. The Herald believed that further state intervention was unnecessary, as trade unions had already demonstrated that they could maintain wages and working conditions. ${ }^{45}$ Both the Evening Post and Otago Daily Times concurred, and the Lyttelton Times went further, lamenting the extent of exploitation in the baking trade, with the caveat that trade unions alone should 'carry any reasonable reforms they determine upon' ${ }^{46}$

\footnotetext{
${ }^{43} \mathrm{NZH}, 17$ May 1890, p.5.

${ }^{44} L T, 27$ March 1890, p.5; ODT, 27 March 1890, p.2.

${ }^{45} \mathrm{NZH}, 17$ May 1890 , p.5.

${ }^{46} L T, 14$ March 1890, p.4.
} 


\section{The Petone Woollen Mill Strike:}

The scholarly lacuna surrounding the Petone Woollen Mill Strike reinforces the notion that historians have neglected aspects of $1890 .{ }^{47}$ One of the year's most protracted disputes, the Petone Woollen Mill Strike began in late January, and lasted over four months. Wellington Woollen Company (WWC) employees stopped work on 12 February in response to the dismissal of 59 workers on the day after company directors discovered the existence of a union. ${ }^{48}$ While the company asserted that falling sales necessitated retrenchment (a claim belied by their annual report), workers believed that the company had acted to crush the Woollen Mill Operatives' Union (WMOU). ${ }^{49}$ Trades and Labour Councils boycotted WWC products, and unions across the colony contributed to a strike relief fund. Arbitration began in early April, but the Wellington TLC's mishandling of evidence complicated proceedings. Eventually the Maritime Council intervened on behalf of the WMOU, and brokered a settlement on 19 June. Although lingering suspicions surrounded the WWC's commitment to the agreement, the firm reemployed between 30 and 40 workers, and on 7 July the Wellington TLC asked the labour community to 'help bring about a revival in their trade, ${ }^{50}$

Although the Petone strike was an isolated regional event, it received colony-wide newspaper coverage. The Grey River Argus and Press ran regular UPA copy on the strike, while the New Zealand Herald published sporadic updates between February and June. Significantly, the Evening Post's editorial coverage of the dispute revealed a series of broad expectations of both capital and labour. The paper's sympathies lay

\footnotetext{
${ }^{47}$ Two exceptions are Barbara Fill, Strike: Trouble at t'Mill, Wellington: GP Books, 1989; Mitchell, 'John Andrew Millar and the New Zealand Labour Movement', pp.33-34.

${ }^{48}$ Interestingly, though nearly 60 female employees joined the strike, gender did not feature in reporting on the strike. For the press at least, picketing female workers were no more remarkable than their male counterparts.

${ }^{49}$ Published on 18 June 1890, the WWC annual report showed that the company had made a $£ 7,000$ profit and paid shareholders an 8 per cent dividend. Fill, Strike, p.39.

${ }^{50}$ EP, 7 July 1890, p.4.
} 
with the garment workers, as available evidence suggested 'certain employés had been dismissed because they joined the Union'. Although the Post encouraged the WWC to reduce unsustainable wages, it believed 'the day has gone by in this colony...when public opinion will tolerate or excuse such tyranny of capital over labour' ${ }^{51}$ However, press sympathy only lasted as long as organised labour remained moderate, in spite of trying circumstances. When the Wellington TLC rejected binding arbitration, the Post castigated the council's temerity. ${ }^{52}$ Similarly, D.P. Fisher's failure to produce written evidence proving that the union had existed before the workers' dismissal was criticised as 'a most extraordinary bungle' that jeopardised the entire case. The duplicity of the WWC had been overshadowed by the 'incompetence' of organised labour. Following the 'fiasco', the paper ceased reporting on the strike, save for news that the Maritime Council had resolved the matter in mid-June. ${ }^{53}$

The 'social norms' frame applied by the Evening Post to the Petone Woollen Mill Strike gained traction in the first half of 1890. Newspapers expressed sympathy for beleaguered unionists, and criticised tyrannical capitalists for imposing cruel working conditions. In reality such sympathy was empty. Despite its advocacy of the right to organise, the Post only endorsed a diluted manifestation of trade unionism. Any threat of disruptive industrial action was censured, but newspapers offered no reliable support in lieu of organised labour's most effective bargaining tactics. Invariably the suggested remedy for workplace ills was the transformative power of negative publicity and sensible negotiation. Sir James Hector, chairman of the Royal Commission on the Grey Valley Mines, expressed such sentiments in his November 1890 report. He believed that wage bargaining occurred within 'reasonable' market

\footnotetext{
${ }^{51} E P, 17$ March 1890, p.2.

${ }^{52} E P, 14$ April 1890, p.2.

${ }^{53} E P, 20$ May 1890, p.2.
} 
constraints, thus strikes were irrational, unnecessary, and altogether 'too grasping'. ${ }^{54}$ To function harmoniously, 'moderate' unionism required evenly matched adversaries. Yet while capitalists devoted their vast resources to maximising profits, even the largest trade unions had few assets and were unable to muster more than one or two fulltime advocates. Until labour achieved some form of parity, capital would not adopt a conciliatory attitude or voluntarily enter negotiations. ${ }^{55}$ The invocation of such expectations and stereotyped industrial actors gave press rhetoric a liberal veneer, but left trade unions hamstrung in any confrontation with a well financed, politically connected adversary. In later disputes this inherently paradoxical frame would dominate newspaper reportage.

\section{Feudalism in New Zealand? The Railways Dispute:}

In early 1890 , labour disputes were small and localised, with few implications for the colony at large. This changed in May, when the spectre of a colony-wide railway strike loomed over faltering negotiations between the Amalgamated Society of Railway Servants (ASRS) and the Railway Commissioners. Railwaymen's 'wages were low and hours long [the 60 hour week prevailed], while seemingly trivial infractions were subject to harsh discipline'. ${ }^{56}$ A railways union had the potential to become a political and industrial force, yet the ASRS only came into existence in $1886 .^{57}$ Harried by management pressure, the union was confined to its Auckland base. The election of a dynamic new leader, James Edwards, in 1889, catalysed an organising campaign that boosted membership to 3,700 in the new year. ${ }^{58}$

\footnotetext{
54 'Report of the Royal Commission on Grey Valley Mines', AJHR, C-3, 1891, p.110; Richardson, Coal, Class and Community, pp.52-53.

${ }^{55}$ Gardner, Prelude to Arbitration, p.124.

${ }^{56}$ Bob Stott and David Leitch, New Zealand Railways: The First 125 Years, Auckland: Heinemann Reed, 1988, p.27.

${ }^{57}$ Nolan, Kin, p.57.

58 'Notes on Trade Union Membership Figures', 1889-1890, Roth Papers, MS-Papers 94-106-29/04, ATL.
} 
The short-lived Railway Commission was unpopular long before the May dispute. $^{59}$ Under the 1887 Government Railways Act, three independent Commissioners (J. McKerrow, J.P. Maxwell, and W.M. Hannay) replaced the General Manager of the Railways Department. Section 27 of the Act shielded the Commission from political interference, effectively giving the Railway Commissioners unbridled power over the railway network. ${ }^{60}$ In February 1890, Auckland businessman Samuel Vaile wrote several articles in the New Zealand Herald advocating railway management reform. Vaile condemned the Commissioners' lack of accountability, likening the Railways Department to a feudal state:

By the passing of the Act of 1887 the entire power and patronage of our railway system, with its 4326 appointments has been placed in the hands of some six or eight families...All these thousands of men hold their posts absolutely by the goodwill of the Commissioners. They therefore dare not offend them. Whatever may happen, they have no appeal. ${ }^{61}$

When tensions escalated in May, the press turned against the railwaymen. Following the ASRS Conference in March, James Edwards sought to meet the Commissioners to discuss reforms proposed by members. ${ }^{62}$ Startled by the union's sudden rise, the Commissioners refused to recognise Edwards as a legitimate representative of their employees. Throughout May, regional branches of the ASRS unanimously voted to allow the Executive to 'resort to extreme measures' if the Commissioners continued their obstinacy. ${ }^{63}$ The threat of a railway strike divided the press. Despite its previous condemnation of the Commissioners, the Herald

\footnotetext{
${ }^{59}$ The Railway Commissioners lasted just seven years. In 1894 the Seddon Government amended the Government Railways Act, replacing the Commissioners with a General Manager accountable to the Minister of Public Works.

${ }^{60}$ The Government Railways Act 1887, s.27.

${ }^{61}$ NZH, 22 February 1890, p.6.

${ }^{62} L T, 13$ March 1890, p.6.

${ }^{63} E P, 22$ May 1890, p.2.
} 
commended their decision to blacklist the ASRS, arguing that employees should be consulted without the pernicious influence of 'professional agitators' that 'live[d] on strikes and labour agitations'. Parliamentarians that attacked the Commissioners were dismissed as 'popularity hunt[ers]' exploiting the issue for political gain. ${ }^{64}$ Other papers replicated the frame used in coverage of the Petone Woollen Mill strike. The Otago Daily Times professed sympathy with the railwaymen, but warned that the strike threat would 'surely alienate public support'. ${ }^{65}$ William Pember Reeves expressed similar sentiments in the Lyttelton Times - condemning the Commissioners' 'don't know you' attitude, while instructing the railwaymen to avoid a 'premature' strike. ${ }^{66}$

Not all newspapers equivocated in their analysis of the dispute. Both the Evening Post and Grey River Argus identified the Railway Commissioners' pugnacious attitude as a threat to industrial harmony. On 20 May, the Post argued that the ASRS had a serious case against the Commissioners, who were obliged to answer such accusations quickly. ${ }^{67}$ The Commissioners delayed for another week, and the paper rebuked their repudiation of union representatives. 'The Commissioners have only themselves to blame... and even now, when forced to give way, they have done so as ungracefully as possible'. By contrast, the ASRS was 'trusted to fairly represent all legitimate grievances'. ${ }^{68}$ The Argus also distrusted the Commissioners, noting, 'their version of the case is not to be relied on as a statement of the real facts as to the working of our railways and the treatment of the men'. ${ }^{69}$ Both papers placed the onus on the Commissioners to resolve the dispute - either by disproving the accusations, or settling with the aggrieved railwaymen.

${ }^{64} \mathrm{NZH}, 20$ May 1890, p.4.

${ }^{65}$ ODT, 17 May 1890, p.2.

${ }^{66} L T, 17$ May 1890, p.4.

${ }^{67} E P, 20$ May 1890, p.2.

${ }^{68} E P, 26$ May 1890, p.2.

${ }^{69}$ GRA, 21 May 1890, p.2. 
Although the threat of a railway strike had dominated headlines, newspapers displayed little interest in the dispute's resolution a month later. Once the colony had avoided the paralysis of its internal transport network, the urgency of railway reform diminished. Most newspapers reported on the June negotiations between the Railway Commissioners and the ASRS, but ignored the resolution in their editorial columns. An agreement, reached after a series of meetings between 16 and 26 June, reduced the working week to 54 hours and introduced accident compensation. Restrictions applied over the next two years would phase out the piecework system and limit boy labour. ${ }^{70}$ While the liberal press celebrated the settlement, conservative newspapers disregarded it. Ignoring its earlier disavowal of 'premature' action, the Lyttelton Times hailed 'one of the most remarkable victories ever won by labour over capital in New Zealand', attributing the victory to 'good organisation' and the railwaymen's ability to 'apply the screw' ${ }^{71}$

The Railway Servants' victory over the stubborn Commissioners was not the only outcome of the June settlement. The New Zealand Herald had introduced a new frame into the press coverage of labour disputes in 1890. Previously, newspapers had tended to hold overzealous capitalists accountable for the eruption of industrial disharmony. Such problems were to be solved by earnest public pressure and patient negotiation, regardless of the strength and belligerence of either party. Yet, mirroring the London Times' assessment of the 1889 Dock Strike, the Herald identified 'professional agitators' as the originators of industrial unrest. Careful not to arouse public indignation by attacking the 'honest toiler', the Herald sought to alienate his intermediary. The union official was depicted as both a dangerous ideologue and brazen opportunist who provoked workers' dissatisfaction to guarantee his income

\footnotetext{
${ }^{70}$ GRA, 27 June 1890, p.4.

${ }^{71} L T, 26$ June 1890, p.4.
} 
and further his political ambitions. Thus, industrial harmony could not be achieved through the growing labour federations, but through direct negotiations between employers and individual workers. Carefully targeted, the frame reinforced a myth of colonial consensus, isolating 'agitators' as renegade voices. Deliberately ignoring the vast power imbalance between the worker and his master, it also presumed a paternalistic benevolence that capitalists seldom displayed.

The railways dispute provided the New Zealand Herald with an opportunity to express its growing frustration with organised labour. Weeks earlier, in an editorial denouncing a miners' strike in Westland, the Herald had signalled a change in its rhetoric on labour issues. In response to a miner's 'unfair' dismissal, the local TLC threatened to strike unless the man was reinstated. Framing the incident as evidence of the unionists' 'desire to tyrannise', the Herald issued a warning to organised labour: 'the Trade Unions are on their trial, and every step is being keenly watched both by enemies and friends'. Trade unions could either reject strikes and command public sympathy, or lose their veneer of legitimacy. ${ }^{72}$ The message was blunt: trade unionism would only be tolerated if labour pursued harmonious relations with capital.

\section{The Benefits of Solidarity - The Shag Point Dispute:}

While historians have overlooked some aspects of New Zealand labour history in 1890, they have also stressed the importance of events that contemporaries overlooked. The Shag Point dispute of May and June is one of the latter. Located 30 miles north of Dunedin, the Shag Point mine opened in 1863, and employed around 35 men in $1885 .^{73}$ Shag Point was a harsh environment - the remote mine was driven into a sheer hill and followed coal seams below sea level, and consequently suffered

\footnotetext{
${ }^{72}$ NZH, 12 May 1890, p.4.

73 S.R.H. Jones, Doing Well and Doing Good: Ross and Glendining, Scottish Enterprise in New Zealand, Dunedin: Otago University Press, 2010, p.160.
} 
frequent flooding. Inspired by the 'development potential of the mine', Dunedin entrepreneurs Edgar Hazlett and Robert Glendining acquired the mine in 1889. The mine was a commercial failure - plagued by flooding, and labour and mechanical difficulties, it remained unprofitable into the 1900s, despite the investment of over $£ 10,000 .^{74}$

Problems arose at Shag Point in early 1890 when the local colliers affiliated with John Lomas' newly expanded Amalgamated Miners' and Labourers' Association (AMALA). As Len Richardson has documented, mine owners were hostile towards unionised workers, fearing that the New Zealand industry would emulate its British counterpart and become a hotbed of class ferment. ${ }^{75}$ On 6 May tensions peaked following the allegation that the miners had mixed stone and coal to exaggerate their productivity. Taking umbrage at the accusation, the president and secretary of the Shag Valley Miners' and Labourers' Association (SVMLA) confronted management, and faced instant dismissal for their insubordination. When the miners struck in protest, over 60 workers and their families were evicted from company housing. ${ }^{76}$ The standoff continued for several weeks until the Maritime Council intervened, dispatching John Millar to negotiate with Hazlett and Glendining. On 14 June, Millar called for a boycott of all goods consigned by or to the owners' business concerns unless the dismissed workers were reinstated. Rattled by the assertiveness of the Council's intervention, Hazlett and Glendining capitulated. Len Richardson and Herbert Roth argue that the Shag Point victory was pivotal for organised labour, demonstrating the power and potential of federation. ${ }^{77}$ Upon his return to Westport,

\footnotetext{
${ }^{74}$ S.R.H. Jones, Ross \& Glendining, Warehouse-Men and Manufacturers: Pioneers in Big Business in Nineteenth Century New Zealand (University of Otago Economics Discussion Paper no. 9513), Dunedin: University of Otago Press, 1995, pp.28-29.

${ }^{75}$ Richardson, Coal, Class and Community, p.18.

${ }^{76}$ ODT, 16 May 1890, p.2.

${ }^{77}$ Richardson, Coal, Class and Community, p.39; Roth, Trade Unions in New Zealand, p.13.
} 
John Lomas received a hero's welcome as unionists celebrated a decisive victory in the 'battle against the power of the few to injure the many' ${ }^{78}$

Newspaper editors were more circumspect in their reporting on the dispute. Aside from the local Otago Daily Times, New Zealand dailies ignored the Shag Point dispute, save for sporadic updates from the UPA telegraph. From the outset, the Otago Daily Times viewed the miners with suspicion. On 10 May, the paper contested the origins of the strike, suggesting that union members had been punished for poor work rather than unfairly treated. The dispute was framed as a test case that demonstrated 'how labour unions intend[ed] to use the power they ha[d] acquired'. ${ }^{79}$ If Shag Point was a test, the Otago Daily Times believed that trade unions had failed. Despite reporting that 'four out of every five disinterested persons' believed Hazlett and Glendining to be 'wrong from beginning to end', the paper perceived the Maritime Council's intervention negatively. ${ }^{80}$ By threatening a general boycott, John Millar had introduced a 'dangerous principle' into the industrial system. In response, the Otago Daily Times warned the Maritime Council 'in their hour of victory to be very careful' ${ }^{81}$ Once again, a combination of assertiveness and cooperation enabled labour to triumph over capital in 1890 . Yet as newspaper coverage demonstrated, challenges to the accepted limits of 'moderate' unionism unsettled the establishment.

\section{The Maritime Council's Biannual Conference:}

While the miners resisted management at Shag Point, the Maritime Council executive assembled in Wellington for its biannual conference. Held between 8 and 19 May, the conference gathered delegates from affiliated trade societies across the colony. Intended as both a review of the Council's achievements and a forum to determine

\footnotetext{
${ }^{78}$ Richardson, Coal, Class and Community, p.39.

${ }^{79}$ ODT, 10 May 1890, p.2.

${ }^{80}$ ODT Supplement, 21 June 1890, p.2.

${ }^{81}$ ODT, 16 June 1890, p.2.
} 
future strategy, the conference had an ambitious agenda. Over the preceding months, the Maritime Council had become the paramount labour organisation in the colony, encompassing not only miners and seamen, but also representatives from a variety of shore-bound occupations. The Petone Woollen Mill and Shag Point disputes ended soon after the conference, and both featured on the Council's agenda. At the conference, the Maritime Council also resolved to celebrate 'Demonstration Day', an annual public holiday to be held on 28 October. The proposed holiday, scheduled on the anniversary of the Council's formation, was intended to celebrate the social, political, and economic achievements of the labour movement. The Council also used the conference to discuss and publicise their ambition to fully realise the goals of new unionism in New Zealand. Among the topics for debate was:

A proposal for the amalgamation of all labour organisations in the colony under one body....which will be able to exercise much more influence and power than the present existing associations can presently wield. ${ }^{82}$

Successfully executed, the plan would see Maritime Council membership swell from 9,750 workers to almost 20,000 , transforming the organisation into one of the most powerful institutions in the colony. ${ }^{83}$

A colony-wide labour federation was a radical, if not unprecedented, proposal in 1890, yet the Maritime Council's bold statement of ambition barely reached the pages of most newspapers. Six months earlier, the left-leaning Grey River Argus repudiated the idea. In November 1889, at a Westport reception, John Lomas instructed workers to transcend parochialism and coalesce into 'one grand union' ${ }^{84}$ In response, the Argus published several letters condemning the proposal. 'An Onlooker' likened Lomas to 'Don Quixote tilting at windmills', criticising his ignorance of economic

\footnotetext{
${ }^{82}$ ODT, 9 May 1890, p.2.

83 'Notes on the Actual and Claimed Membership of the Maritime Council', 1889-1890, Roth Papers, MS-Papers 94-106-29/04, ATL.

${ }^{84}$ Otago Witness, 21 November 1889, p.15; Richardson, Coal, Class and Community, pp.39-40.
} 
principles. The correspondent argued that labour federations distorted the market and ultimately collapsed wages. ${ }^{85}$ Later, on 1 April 1890, at a Canterbury TLC meeting, Lomas urged the colony's workers to 'amalgamate into one strong body', yet the Press ignored his call for action. ${ }^{86}$

Why did newspapers ignore the Maritime Council's provocative declaration? Although journalists were excluded from the conference, newspapers printed syndicated daily summaries of the proceedings. Certainly, all reported that the Council intended to discuss the possibility of forming a colonial labour federation. However, in 1890 both liberal and conservative newspapers appeared unwilling to consider domestic labour issues other than strikes and disputes. Aside from the Evening Post's attack on the Sweating Commission, newspaper editorials only addressed instances of industrial conflict - a selective treatment that reinforced negative public perceptions of organised labour. Astonishingly, in 1890 the Press did not publish a single editorial on labour issues until 5 August. Although the Maritime Council conference occurred while workers picketed in Otago and Wellington, and railwaymen across the colony threatened to stop work, the lack of editorial response to the proposal indicated a general disregard for organised labour outside the combative realm of industrial conflict.

\section{Bad Intentions or Bad Publicity? The Grey Valley Coal Company Strike:}

Economic deterioration not only encouraged the organisation of previously isolated mining communities, but also forced previously independent mining companies to amalgamate. The Westport Coal Company (WCC) was established in 1879 and its directors intended to replicate the success of the British coal barons. ${ }^{87}$ Yet, by the

\footnotetext{
${ }^{85}$ GRA, 3 December 1889, p.4.

${ }^{86}$ Press, 1 April 1890, p.6.

${ }^{87}$ Richardson, Coal, Class and Community, pp.17-18.
} 
early 1880s, imprudent expansion, boardroom infighting, and the loss of half a year's production during the 1884-1885 Denniston strike financially crippled the company. To keep West Coast mining operations solvent, in 1886 the Union Company consolidated the Grey Valley mines under the aegis of the Grey Valley Coal Company (GVCC). Eager to secure an assured fuel supply at a fixed price, the Union Company extended its monopoly over maritime transport into the energy sector. ${ }^{88}$ Ownership of the GVCC allowed the Union Company to influence the price, output, and distribution of the colony's domestic coal supply, and created a powerful conglomerate hostile to the interests of organised labour. The 'secret working arrangements and private understandings' of monopoly capitalism had arrived on the West Coast. $^{89}$

Relations between labour and the new management were uneasy from the outset. Gavin McLean argues that the Union Steam Ship Company ran the Grey Valley mines entirely in its short-term interests. They invested little money in the operation and searched ceaselessly for opportunities to economise. ${ }^{90}$ Yet the mine remained unprofitable, reporting a net loss approaching $£ 17,000$ in $1890 .^{91}$ Furthermore, workers resisted the erosion of their privileges and the extension of management prerogative. Miners implemented work sharing, reduced working hours at the coalface, and doggedly refused to relinquish their traditional holidays. In December 1889, the Grey Valley Miners’ Association (GVMA) successfully resisted a 12.5 per cent wage reduction, yet on 1 July management tabled a vindictive ultimatum: the miners should either accept a 20 per cent cut in hewing rates or operate the mines on lease from the company. If neither proposal were accepted, the mines would close.

\footnotetext{
${ }^{88}$ In 1884 , the company consumed 113,391 tons of coal - nearly a quarter of the colony's total annual production. McLean, The Southern Octopus, p.85.

89 ibid., p.95.

${ }^{90}$ ibid., p.94.

91 'The Labour Dispute on West Coast of Middle Island (Correspondence Relative To)', AJHR, H-52, 1891, pp.4-5.
} 
The scheme was designed to cripple the local union; keeping the mine idle would isolate the miners from the wider labour community and force hundreds of workers to leave the valley. After careful consideration, the GVMA rejected the proposal, and were locked out. Despite his radical convictions, John Lomas was reluctant to enter a prolonged confrontation with management. Three weeks after the mine closed, the GVMA accepted a wage reduction of $5 \mathrm{~d}$. per ton (less than the initial proposal of between 6 and 12d.) and work resumed on 1 September. ${ }^{92}$

The varied responses to the Grey Valley lockout suggest that news frames were not hierarchically imposed in the New Zealand press. Only the liberal press commented on the dispute, yet no newspaper supported either camp unreservedly. When GVCC management delivered its ultimatum, both the Lyttelton Times and Grey River Argus instructed both sides to be patient, eager to prevent imprudent decisions from crippling the local economy. ${ }^{93}$ The Argus understood the gravity of the GVCC's financial difficulties, but believed, as the miners did, that costs ought to be reduced throughout the business, not solely in workers' wages. ${ }^{94}$ The Evening Post agreed, and contrary to its earlier cynicism regarding the motives of the Wellington Woollen Company, argued that, once revealed, the 'facts' would depict the GVCC in a favourable light. Furthermore, it contended that colliers were among the highest paid workers in the colony, thus they could afford wage reductions to avert the company's bankruptcy. ${ }^{95}$ The Argus agreed, assuming it was 'safe to say' that colliers earned reasonable wages. ${ }^{96}$ Later, after 'careful enquiry' into the case, the Post withdrew its support for the mining conglomerate. Underneath a letter outlining the proposed wage system from GVCC Managing Director Martin Kennedy, an editorial postscript

\footnotetext{
${ }^{92}$ GRA, 7 July 1890,p.2; Richardson, Coal, Class and Community, pp.41-43.

${ }^{93}$ GRA, 2 July 1890, p.2; LT, 21 July 1890, p.4.

${ }^{94}$ GRA, 14 July $1890, \mathrm{p} .2$.

${ }^{95} E P, 21$ July 1890, p. 2.

${ }^{96}$ GRA, 14 July 1890, p.2.
} 
informed readers 'that the rates of pay offered to and refused by miners are less than those current in other collieries'.97

After the lockout began, the Grey River Argus continued reporting on the dispute, despite diminishing interest in the Grey Valley miners. In addition to emphasising the unfair burden wage cuts placed on the miners, the Grey River Argus condemned unionist tactics that could jeopardise the regional economy. When rumours surfaced that the GVMA intended to call out the pump men, effectively crippling the entire operation, the Argus chastised the would-be saboteurs. ${ }^{98}$ The Grey Valley mine shafts stretched below sea level, thus serious flooding would permanently close the operation. When the Argus reviewed the dispute on 13 August, it argued that the miners' chief problem was publicity. The paper believed that the miners held the sympathy of 'the public and Press alike', but had failed to publicise their agenda, wasting an opportunity to pressure the GVCC. Despite the devastating consequences of a protracted lockout, the miners had neglected to inform the public of the precarious position the GVCC had engineered. Stating that 'the whole tendency of the thought of the great majority of the people...is strong sympathy with the toiling masses - with, in short, flesh and blood as against money grubbing', the Argus argued that the cause of organised labour resonated strongly with New Zealanders the challenge for its leaders was to devise and disseminate the rhetoric to unleash the silent majority. ${ }^{99}$

\section{An 'Altogether Unjustifiable' Strike - The Marine Officers' Dispute:}

By mid-1890, the industrial harmony boasted of by 'colonising crusaders' and politicians was under serious pressure. A week after the GVCC delivered its

\footnotetext{
97 The new pay scale offered miners the chance to earn around 12s. per day, and labourers around 9s. per day. The average wage for an unskilled worker was 6s. per day. EP, 23 July 1890, p.4.

${ }^{98}$ GRA, 4 August 1890, p.2.

${ }^{99}$ GRA, 13 August 1890, p.2.
} 
ultimatum, the Mercantile Marine Officers' Association of New Zealand (MMOA) threatened to strike. Ships' officers established the MMOA in late 1889 as they sought to distinguish their interests from those of ordinary crewmen. The FSU responded angrily, expelling all MMOA members. ${ }^{100}$ However, by July the MMOA had affiliated with the Maritime Council, and Conrad Bollinger claims the bodies shared a 'fraternal understanding' born of their common interest as maritime workers. ${ }^{101}$ Led by J.H.W. Highman, the MMOA came to prominence on 7 July when it threatened to strike unless employers offered sizeable wage increases and employed a minimum of three officers per vessel. With the assistance of the Maritime Council, Highman believed that the ship-owners would capitulate. Yet John Millar was unconvinced, advising Highman to delay the strike as the Maritime Council 'decline[d] to be plunged into trouble before having ample proof that demands refused [were] reasonable'. ${ }^{102}$ Millar considered the officers' demands extravagant, and instead volunteered to arbitrate the dispute. Without the backing of the Maritime Council, the MMOA retreated, and Highman agreed to meet with George McLean, Chairman of the Union Company. The negotiations were swift, and a secret agreement preventing the strike was reached on 24 July.

Newspapers praised John Millar's intervention, declaring the Maritime Council a welcome moderate element in union circles. In a report on the threatened strike, the Otago Daily Times published 'private' remarks attributed to Millar, in which he stated his reluctance to jeopardise the livelihoods of 20,000 men on behalf of just 300 officers. The Times attributed his caution to Maritime Council's 'breadth of foundation' - mass organisation allowed labour to negate the demands of fringe

\footnotetext{
${ }^{100}$ Atkinson, 'Auckland Seamen and their Union', p.33.

${ }^{101}$ Bollinger, Against the Wind, p.30.

${ }^{102}$ Salmond, New Zealand Labour's Pioneering Days, p. 81.
} 
elements. ${ }^{103}$ The Evening Post expressed similar sentiments, applauding Millar's 'timely and proper' intervention for preventing an 'altogether unjustifiable' strike. ${ }^{104}$

Yet the Evening Post did not believe that Millar alone had placated the marine officers. The paper hailed George McLean's decision to publicise his correspondence with the MMOA as an integral factor in the cancellation of the strike. All six newspapers printed their correspondence, intended to discredit the union, without providing Highman a right of reply. The letters, written between 26 May and 8 July, were publicised in an admittedly desperate attempt to thwart the strike by George McLean, who acknowledged that Highman had not sanctioned their publication. ${ }^{105}$ The Post argued that McLean had acted in the public interest, and astoundingly no newspaper questioned the authenticity of the correspondence. The maritime officers' demands were unpopular, and the story gave newspapers an opportunity to attack 'radical' elements within the labour movement. By simultaneously praising the Maritime Council and criticising the MMOA, the press reinforced the notion that the strike was an ideological line separating reasonable unionists from greedy agitators.

By the late 1880s, two decades of labour organisation and agitation had begun bearing fruit. Broad-based unions were established and had successfully fought for improved working conditions. Rather than campaigning in isolation, organised labour began operating in a 'spirit of national unity'. ${ }^{106}$ Despite the lack of a genuine labour presence in the press, newspapers appeared bemused by, rather than immediately hostile to, the newly assertive labour movement. Editorial responses to the London Dockers' Strike were prefaced with sympathy for the workers, yet the mass organisation and trans-colonial appeal that aided their cause divided the press. For

${ }^{103}$ ODT, 10 July 1890, p.2.

${ }^{104} E P, 9$ July 1890, p.2.

${ }^{105} E P, 9$ July 1890, p.2.

${ }^{106}$ Thorn, The Formation and Development of Trades Unionism in Canterbury, p.23. 
most, new unionism was a foreign phenomenon worthy of investigation, without offering insights about domestic labour. The nascent Maritime Council was not entirely ignored, yet the paucity of debate over an organisation that advocated the incorporation of all New Zealand workers suggests that editors did not fully comprehend its influence.

From April, the proliferation of industrial disputes across the colony prompted newspapers to clarify their positions on the revitalised labour movement. Remarkably, little separated the opinions expressed by recognised 'liberal' and 'conservative' newspapers. As a rule, both tended towards an increasingly negative framing of labour issues as industrial unrest intensified. The strike was never a popular negotiating tactic, but the escalation of industrial disharmony and the overt influence of the Maritime Council worried the press. Disputes in early 1890, like the Petone Woollen Mill Strike, were considered undesirable, but not as sinister examples of the union official's creeping influence. Shocked by the threat that federated workers posed to vital industries and their willingness to transcend trade unions' traditional focus on work and wages, the tone of newspaper coverage grew more strident towards the middle of the year. Moderate unions and organisers were tolerated, but newspapers stressed the division between desirable and undesirable unionism, with the strike as metaphorical line in the sand. In the dedicated union official, architect and assertive face of the newly confident labour movement, a new 'public enemy' was recognised. On 1 July, the New Zealand Herald warned readers of the dangers of an assertive labour movement. In a few years, trade unions had transformed from small benefit societies to powerful interest groups. This rapid rise, the Herald feared, not only led trade unions to ignore the plight of non-unionised workers, but to consolidate their stranglehold over the workplace and 'strike for 
wages that [would] command luxuries' - an unmitigated horror for the colonial elite. ${ }^{107}$

${ }^{107}$ NZH, 1 July 1890 , p.5. 


\section{Chapter Three: Entangling Alliances? The Arrival of the Maritime Strike in New Zealand.}

As the economy slackened into winter, industrial relations deteriorated. Minor disturbances threatened to boil over into serious disputes. Amid growing press unease with labour federation, the climate favoured belligerent employers over the loose network of trade unions. Flashpoints in July and August catalysed underlying tensions between capital and labour, eventually resulting in the outbreak of the Maritime Strike, the largest industrial dispute in New Zealand's history. At issue was the principle of union recognition, a contest fundamental to the industrial system, but one that lacked the emotive appeal of disputes over wages and working conditions. The upheavals of the coming months revealed the fallacy of the much-heralded 'moderate' unionism, which required rigorous press scrutiny to level the vast imbalances between workers and their employers. Confronted with threats to colonial stability and prosperity, conservative newspapers abandoned the last vestiges of impartiality, seizing an opportunity to marginalise union leaders - portrayed as the instigators and sole beneficiaries of the strike. Newspapers exaggerated the gravity of industrial disturbances, both major and minor, as editors sought to mobilise public opinion, often contradicting the nationally syndicated reporting that filled their newspapers. Confronted by an aggressive cadre of employers and a baying press, liberal newspapers wilted, offering scant defence of the unions, while quietly blaming employers for the impasse.

James Mills' Union Steam Ship Company played a leading role in the industrial turmoil that engulfed New Zealand in the second half of 1890. Mills founded the Union Company on 12 July 1875 to compete for a share of the lucrative coastal shipping trade, which exceeded two million tons annually, and doubled to four 
million tons by $1890 .^{1}$ Determined to avoid the erosion of his authority via a public share offer, Mills forged a syndicate of Scottish and Dunedin investors to finance the initial purchase of five steamers. Through the $1870 \mathrm{~s}$ and $1880 \mathrm{~s}$, the company embarked upon a process of steady expansion, monopolising domestic shipping within 15 years of its inception. Rather than aggressively assimilating smaller companies, Mills preferred the slow acquisition of assets and judicious mergers, careful to avoid overstretching his capital. In 1880, the company listed on the London Stock Exchange, and consequently the British share of its capital rose to 87 per cent. The Union Company first offered trans-Tasman services in 1876, and quickly prospered, cleverly combining passenger and cargo routes with government mail subsidies. Protected by its 'Tasman moat, [the company] developed along semimonopolistic lines', dominating the domestic market, then expanding across the Pacific. By 1890, the line boasted a fleet of 43 steamers, with nominal capital of $£ 1$ million. $^{2}$

Strict managerialism and hierarchal discipline underpinned the success of the Union Company. In 1879, the company produced a comprehensive series of standing orders to regulate procedures across its fleet. Unofficially known as the 'Union Company Bible', the handbook exemplified Mills' authoritarian streak. ${ }^{3} \mathrm{He}$ concentrated power in the hands of his managers and imposed strict discipline throughout the company. Employees were rewarded for good service, but transgressors suffered harsh punishments. Combined with the Union Company's remarkable influence in all aspects of colonial political and economic life, the tight control Mills exerted over his employees led enemies to nickname his business 'the

\footnotetext{
${ }^{1}$ Simon Ville, 'The Coastal Trade of New Zealand Prior to World War One', NZJH, Vol. 27, no. 1, April 1993, pp.76-77.

${ }^{2}$ McLean, The Southern Octopus, pp.26-49, 193.

${ }^{3}$ Gordon McLauchlan, The Line That Dared: A History of the Union Steam Ship Company 1875-1975, Mission Bay: Four Star Books, 1987, p.23.
} 
Southern Octopus'. While Mills tolerated trade unionism, his authoritarian style left little room for compromise. Upon the establishment of the Victoria Marine Masters' and Mates' Union in 1885, he immediately circularised the company's masters, demanding information about employees who had joined. Later, pre-empting the dispute with the MMOA, the Board of Directors stated: 'it is undesirable that Masters should join the union, and further, that the Directors would stand by Masters not joining' ${ }^{4}$

\section{Capitalist Counter-mobilisation - The Whitcombe and Tombs Affair:}

The rise of the Maritime Council stalled in July, when it suffered an embarrassing defeat at the hands of Christchurch stationers Whitcombe and Tombs. Founded in 1883 by master printer George Tombs and entrepreneur George Whitcombe, the company printed and retailed books. Although Tombs established the Canterbury Master Printers' Association (CMPA) in 1889, and served as its inaugural president, he had a reputation for harsh employment policies - a concern the Sweating Commission addressed in March. ${ }^{5}$ In February 1890, the Canterbury Typographical Association (CTA) submitted a list of workplace reforms to the CMPA. In early March, CMPA members met with the CTA and fixed a minimum weekly pay rate of $£ 2.15 \mathrm{~s}$. Whitcombe and Tombs abstained from the agreement, as it required that they pay equal wages to their female compositors. ${ }^{6}$ Following the meeting, Whitcombe and Tombs instructed its bookbinders to leave the union, and dismissed those who refused. Initial negotiations failed, and in May the CTA requested the Maritime

\footnotetext{
${ }^{4}$ McLean, The Southern Octopus, pp.45, 100-07.

${ }^{5}$ Noel Waite, Books for a Nation: The Whitcoulls Story, Auckland: Whitcoulls, 2008, p.32; AJHR, H5, 1890, pp.43-47.

${ }^{6}$ A.E.J. Arts, A History of the Canterbury Master Printers' Association 1889-1989, Christchurch: Printing Industries Association of Canterbury, 1989, p.13.
} 
Council's assistance. Unable to persuade Whitcombe and Tombs to negotiate, on 31 July John Millar called for all transport workers to boycott the firm's cargo. ${ }^{7}$

Millar's hopes of a prompt settlement were dashed on 11 August, when the Railway Commissioners and Union Company both declined his request to withhold carriage of Whitcombe and Tombs' goods. Furthermore, the Commissioners notified Millar that employees who refused duty would be dismissed. Cowed by the Commissioners' announcement, the railwaymen withdrew from the proposed boycott. $^{8}$ Without the support of the ASRS, the boycott was untenable, yet newspapers exaggerated the aggression of the Maritime Council's statements. On 4 August, the Press described the boycott of a local business as a matter 'involv[ing] the unity of all the labour organisations in the colony, and they are determined to fight it out to the death'. ${ }^{9}$ The following day's editorial inflated the threatened boycott into a rumoured general strike. Ignoring Whitcombe and Tombs' provocations, the paper argued that Christchurch citizens would repudiate organised labour if the 'strike' occurred. ${ }^{10}$ To emphasise the disastrous consequences of economic disruption, the Press interviewed local businessmen to ascertain 'the probable effect of extreme measures as regards the public'. Belying the story's ominous brief, the Press found few informants willing to predict the impending catastrophe imagined by its editor. $^{11}$

While the Press refused to acknowledge Whitcombe and Tombs' belligerence, most newspapers criticised the publisher without offering organised labour any hope of redress. The Otago Daily Times contended that the threatened boycott arose from Whitcombe and Tombs' 'excessive combativeness' and 'unaccommodating spirit'.

\footnotetext{
${ }^{7}$ Typo, 30 August 1890, p.87.

${ }^{8}$ Peter Franks, Print and Politics: A History of Trade Unions in the New Zealand Printing Industry, 1865-1995, Wellington: Victoria University Press, 2001, p.44.

${ }^{9}$ Press, 4 August 1890, p.5.

${ }^{10}$ Press, 5 August 1890, p.4.

${ }^{11}$ Press, 7 August 1890, p.5.
} 
However, by 'resorting to extreme measures', the Maritime Council had committed a greater sin. Ignoring the stationers' disdain for negotiation, the paper believed that the principle of union recognition was best upheld via public pressure. ${ }^{12}$ The Lyttelton Times concurred, lauding Millar for 'so repeatedly holding out the olive branch', but criticising his threat to disrupt the local economy. ${ }^{13}$ An early advocate of the 'social norms' frame, the Evening Post applied a similar analysis to the story. On 11 August, the paper reprinted a lecture on 'boycotting' given by the Reverend Joseph Berry at the Taranaki Street Wesleyan Hall. While Berry argued 'this firm in Christchurch ought to be thoroughly dealt with', he refused to condone the boycott as an acceptable means of forcing arbitration, considering it antagonistic and infectious. Instead, he instructed the Maritime Council to rely on the public to coerce Whitcombe and Tombs into accepting arbitration. ${ }^{14}$ Once again, newspapers professed to promote the principles of labour organisation while condemning their practice.

An emergency meeting of Whitcombe and Tombs shareholders on 12 August stoked fears that the threatened boycott would escalate into a general strike. When arbitration was voted on, shareholders representing 80 per cent of the company's ownership decided against negotiation with the Maritime Council. ${ }^{15}$ Social pressure had demonstrably failed to sway Whitcombe and Tombs, yet not even this stark display of arrogance prompted newspaper editors to reframe their analysis of the dispute. The Evening Post reacted by labelling the firm 'selfish and inconsiderate in the extreme', but continued to denounce the boycott, adding that any disruption of trade would further antagonise the public. ${ }^{16}$ On 14 August, the Lyttelton Times summarised events, emphasising three 'errors' that had aggravated the standoff:

\footnotetext{
${ }^{12}$ ODT, 4 August 1890, p.4.

${ }^{13}$ LT, 9 August 1890, p.4.

${ }^{14} E P, 11$ August 1890, p.4.

${ }^{15}$ Press, 13 August 1890, p.5.

${ }^{16}$ EP, 13 August 1890, p.2.
} 
Whitcombe and Tombs' rejection of the CMPA agreement; the Maritime Council's announcement of the boycott (redeemed by their offer of arbitration); and finally, Whitcombe and Tombs' refusal to negotiate with labour representatives. Despite reporting that Whitcombe and Tombs had both instigated and prolonged the dispute, William Pember Reeves cautioned against suspicions of a sinister anti-union plot: 'We shall continue to discredit the existence of any capitalist secret society until we see the most direct proof to the contrary'. ${ }^{17}$

On 16 August John Millar confirmed rumours that the Maritime Council had cancelled the Christchurch boycott in a widely published open letter. After condemning Whitcombe and Tombs, Millar expressed his gratitude to labour organisations across Australasia and asked the public to 'mark their appreciation of this Company's tactics by refraining from purchasing their goods'. He justified the Council's moderation as a concession necessary to protect the interests of the wider labour community. ${ }^{18}$ The Evening Post saluted the Maritime Council's 'great moral victory', as Millar's probity had saved the colony from a general strike. ${ }^{19}$ The Lyttelton Times concurred, congratulating the Maritime Council executive on 'the excellent sense shown by them in the face of undoubted provocation' ${ }^{20}$ Despite having demanded Millar retract the strike threat, the conservative press responded to the 16 August declaration with scorn. Although the Otago Daily Times expressed relief at the boycott's cancellation, the paper alleged that the decision resulted from internal disharmony as opposed to 'a genuine recognition of the iniquity of so terrible a venture for so slight a cause'. ${ }^{21}$ The New Zealand Herald concurred, stating that indecisiveness scuppered the strike, and hailed the Railway Commissioners for

\footnotetext{
${ }^{17}$ LT, 14 August 1890, p.4.

${ }^{18}$ Press, 16 August 1890, p.5.

${ }^{19}$ EP, 16 August 1890, p.2.

${ }^{20} L T, 18$ August 1890, p.4.

${ }^{21} O D T, 18$ August 1890, p.2.
} 
breaking the Maritime Council's grand coalition. ${ }^{22}$ Astonishingly, the Press took credit for Millar's decision, arguing that its reportage had shown the Maritime Council 'the meaning of the disaster which they sought to bring upon the city'. ${ }^{23}$

While newspapers praised the Maritime Council for averting a general strike, the railway servants' defection revealed a fundamental weakness in the federation. Conrad Bollinger argues that the defeat of the colony's largest labour organisation encouraged employers to adopt a belligerent stance toward dispute mediation. ${ }^{24}$ In a slack labour market, employers could act ruthlessly against organised workers, diminishing the effectiveness of industrial action. Furthermore, the invocation of an idealised public, indignant at injustice and eager to maintain an equitable society was a convenient myth that allowed newspapers to promote the principles of labour organisation while condemning their practice. The Whitcombe and Tombs dispute had dragged on since March, during which period the firm was the subject of an ineffectual Sweating Commission investigation. Although newspapers retained their faith in the self-regulating egalitarianism of colonial society, public pressure had failed to persuade the company to even negotiate with its employees' representatives. Organised labour had lost momentum - the image of a robust workers' coalition able to protect members' interests had been tarnished.

The Whitcombe and Tombs imbroglio marked a rhetorical shift in the framing of labour issues for some newspapers, and provided others with fresh ammunition against 'troublemakers'. Responding to events in Christchurch, on 9 August the New Zealand Herald published an attack on new unionism, outlining a gloomy vision of the colony's future if the labour movement maintained its influence. Positioning itself as a defender of 'the community at large', the Herald likened contemporary industrial

\footnotetext{
${ }^{22}$ NZH, 18 August 1890, p.4.

${ }^{23}$ Press, 20 August 1890, p.4.

${ }^{24}$ Bollinger, Against the Wind, p.36.
} 
relations to the medieval state of perpetual war. Industrial unrest was considered an inevitable consequence of labour federation - the 'united phalanx' of trade unions alienated management from workers. Employers had become the 'absolute slave' of labour, and the future promised mass capital withdrawal and prolonged economic stagnation. ${ }^{25}$ The Press believed that the rise of new unionism had led 'all men of business' to view labour with apprehension. ${ }^{26}$ J.M. Ritchie, one of Dunedin's preeminent businessmen, echoed the paper's suspicions in correspondence with James Mills - 'unless we can organise as employers - we can be crushed as it is' ${ }^{27}$ In the aftermath of the dispute, the Evening Post postulated that the emergence of the Maritime Council put labour on an equal footing with capital. For the Post, 'parity' required labour to respect the 'rights of capital'. ${ }^{28}$ Classifying such mismatched adversaries as 'equals' allowed the paper to modify its stance on organised labour while retaining a liberal veneer. The Maritime Council's hasty resort to 'extreme measures', in what the public considered a minor dispute, ultimately homogenised editorial perspectives on the labour movement.

\section{Origins and Outcomes of the Australasian Maritime Strike:}

Seeking to resist the surge of new unionism, Australasian capitalists began countermobilising in the late 1880 s. In New Zealand, such organisations relied on existing trade associations. Loose groups of employers only coalesced into formal organisations after the Maritime Strike began. ${ }^{29}$ By contrast, Australian capitalists vigorously protected their interests, and viewed organised labour with considerable hostility. Throughout the previous decade, Australian industrial disputes had evolved

\footnotetext{
${ }^{25}$ NZH, 9 August 1890, p.4.

${ }^{26}$ Press, 20 August 1890, p.4.

27 J.M. Ritchie to James Mills, 28 July 1890, Private Outward Letter Book, no. 5, (1888-90), in Gardner, Prelude to Arbitration, p.114.

${ }^{28}$ EP, 22 August 1890, p.2.

${ }^{29}$ Gardner, Prelude to Arbitration, p.115.
} 
from isolated questions of individual security towards cooperative agitation in support of union principles (a process compressed into a few years in New Zealand).$^{30}$ In response, employers' associations, including the Pastoralists Union, the Steam Ship Owners' Association (SSOA), Employers' Unions, and Chambers of Manufactures, sought to both negate the advances achieved by organised labour and defy demands for further concessions. The employers aimed to reaffirm the 'freedom of contract' - a phrase designed to emphasise the ostensible tyranny of unionism, while concealing employers' intent to undermine workers' bargaining position. The principle asserted employers' right to negotiate with individual workers, and denied unions' right to enforce a 'closed shop' ${ }^{31}$ In July 1890, SSOA chairman W.C. Willis typified employers' attitudes when he remarked:

All the owners throughout Australia have signed a bond to stand by one another...They are a combined and compact body, and I believe that never before has such an opportunity to test the relative strength of labour and capital arisen. ${ }^{32}$

Combined with their aggression, the dogmatic conception of industrial relations as a zero-sum game led Australian employers into conflict with organised labour. Exacerbated by a faltering economy, the Australian Maritime Strike arose from a series of minor clashes magnified by both sides' refusal to compromise on 'fundamental' principles. James Bennett argues that the term 'Maritime Strike' is a misnomer because it originated with the intertwining of problems in the maritime industry and the shearing sheds, and ultimately encompassed workers far beyond either industry. ${ }^{33}$ Established in 1886 , the ASU claimed by 1890 to have orchestrated

\footnotetext{
${ }^{30}$ Malcolm Waters, Strikes in Australia: A Sociological Analysis of Industrial Conflict, Sydney: Allen \& Unwin, 1982, p.102.

31 Ian Turner and Leonie Sandercock, In Union is Their Strength: A History of Trade Unions in Australia, 1788-1983, Melbourne: Thomas Nelson, 1974, $3^{\text {rd }}$ edition, 1983, p.40.

${ }^{32}$ B. Fitzpatrick, A Short History of the Australian Labour Movement, Melbourne: MacMillan, 1940, $2^{\text {nd }}$ revised edition, 1968, p.113.

${ }^{33}$ Bennett, 'Rats and Revolutionaries', p.35.
} 
3,180 strikes and organised 85 per cent of the 2,792 shearing sheds in South Australia, Victoria, and New South Wales. ${ }^{34}$ Protesting the exclusion of unionised workers from the Jondaryan Station in Queensland, in May 1890 ASU President William Spence organised an embargo of non-union wool in unison with local maritime workers. Spence's effort to force employers to recognise the Queensland Shearers' Union succeeded, but antagonised employers while exaggerating organised labour's confidence. ${ }^{35}$ In subsequent weeks, Spence travelled to Melbourne to persuade the Trades Hall Council, Seamen's Union, and Wharf Labourers to assist in future boycotts. $^{36}$

Using the Jondaryan model, Spence planned to force New South Wales pastoralists to recognise the ASU, yet his campaign coincided with a disagreement brewing between ship-owners and maritime officers. Three weeks before Spence published his 1 July manifesto outlining the struggle to prevent the export of nonunion wool, the Australian MMOA had issued a series of demands to the SSOA. Their claims included a proposal to increase wages, introduce a ten hour day, and reform shipboard practice. The owners initially appeared amenable to the officers' requests. However, on 19 July, the SSOA informed the officers that their requests would only be considered if they severed their affiliations with federated labour. Stuart Svensen regards the affiliation dispute as a 'pseudo-issue', designed to provoke a confrontation. Aside from the Melbourne branch, the officers were not affiliated with any trade organisations, yet ship-owners feared they would collaborate with the ASU and resume hostilities at the peak of the wool season. Instead, the SSOA conspired to precipitate a dispute at a moment of financial and organisational

\footnotetext{
${ }^{34}$ Waters, Strikes in Australia, p.99.

35 J.A. Merritt, 'W.G. Spence and the 1890 Maritime Strike', Australian Historical Studies, Vol. 15, no. 60, April 1973, pp.603-04.

${ }^{36}$ Mark Hearn and Harry Knowles, One Big Union: A History of the Australian Workers Union 18861994, Melbourne: Cambridge University Press, 1996, p.43.
} 
weakness for the inter-colonial labour federations. The benefits of their gambit were obvious: defeat of the maritime unions would end pressure to improve wages and working conditions, and consolidate members' control over Australian shipping. ${ }^{37}$

Displaying his disdain for negotiation, W.C. Willis met with a group of retired masters on 31 July and established a puppet union, the Mercantile Marine Service of Australia. Ship-owners granted the bogus organisation increased wages in exchange for a promise 'not to work into the hands of any labour organisation'. ${ }^{38}$ Enraged, the officers issued an ultimatum on 7 August; if the SSOA refused to meet their demands within a week, all officers would stop work. Neither side relented, and on 16 August Australian shipping came to a halt when the officers walked out, followed by miners, railwaymen, dockworkers, and shearers. Within a week, 59 vessels were laid up, and over 5,000 men had left work, yet New Zealand shipping continued unabated. ${ }^{39}$ Eager to avoid the dispute, John Millar assured the Union Company that unionised seamen would continue working inter-colonial routes provided that the closed shop remained. $^{40}$

Shunning Millar's overtures, the Union Company acquiesced with the uncompromising approach adopted by the SSOA at its 23-24 August meeting in Albury. Ship-owners endorsed two major resolutions: the dismissal of any officer with trade union associations and an assertion of employers' right to operate an open shop. Acting-manager David Mills demonstrated the company's commitment to the agreement by employing non-union labour to unload the Tarawera in Sydney on 25 August. Alongside the Albury declaration, the Maritime Council interpreted the decision as an act of aggression that rendered the continued employment of New

\footnotetext{
${ }^{37}$ Stuart Svensen, The Sinews of War: Hard Cash and the 1890 Maritime Strike, Sydney: University of New South Wales Press, 1995, p.88.

${ }^{38}$ McLean, The Southern Octopus, p.108.

${ }^{39}$ Svensen, The Sinews of War, p.113.

${ }^{40}$ McLean, The Southern Octopus, p.109.
} 
Zealand maritime unionists untenable. ${ }^{41}$ The following day, Millar instructed workers on inter-colonial routes to give 24 hours notice, but allowed the Union Company to maintain coastal services. Sir Robert Stout later remarked that 'the Union Company, therefore, with its eyes open, practically invited a strike'. ${ }^{42}$ Why did the Union Company forgo conciliation? Gavin McLean argues that James Mills prioritised cordial relations with competitors over preventing short-term industrial unrest. Thus, compliance with the SSOA was primarily an economic decision - if the strike forced his Australian competitors to abandon their traditional routes, they would challenge the Union Company's dominance of lucrative inter-colonial services. In August, the company was prepared to withstand a strike; trade was slack, unemployment was rising, and the company held over 11,000 tons of reserve coal. ${ }^{43}$ If securing future prosperity entailed a confrontation with his employees, James Mills was happy to undermine the emerging Australasian labour movement.

New Zealand coastal shipping continued uninterrupted until 28 August, when the Union Company vessel Wairarapa left Port Chalmers manned by a non-union crew. The next day, John Millar instructed all junior officers, dockers, seamen, cooks, and stewards to leave their posts. By the end of August, most unionised maritime workers had walked out, temporarily paralysing domestic shipping. The strike spread inland, and by early September, miners affiliated with the Maritime Council left work, protesting their employers' failure to sever ties with the Union Company. The move sparked fears of coal and food shortages, exacerbated by previous production stoppages. Few reliable estimates exist, yet historians generally accept that around 8,000 left work across New Zealand between August and November 1890, although

\footnotetext{
${ }^{41}$ Merrett, A Reappraisal of the 1890 Maritime Strike', pp.72-77.

${ }^{42}$ Reeves, State Experiments in New Zealand and Australia, Vol. 2, pp.87-88.

${ }^{43}$ McLean, The Southern Octopus, pp.114-15.
} 
few participated for the duration. ${ }^{44}$ Within weeks the strike faltered, as haphazard organisation, public animosity, and financial weakness exposed the fragility of the Maritime Council's grand coalition. Vast coal reserves enabled the Union Company to resume core services almost immediately, and the ports quickly reopened, manned by 'gentlemen' volunteers, farmers, and unemployed labourers. ${ }^{45}$

The railwaymen's participation was crucial to a successful general strike, yet the ASRS refrained from joining, fearing the Railway Commissioners' retribution. Painfully aware of their employer's intolerance of industrial action, ASRS members acted with extreme caution, undermining the attempt to obstruct domestic transportation. ${ }^{46}$ After the Commissioners connived to press their employees into strike-breaking on the Lyttelton wharves, and dismissed 150 men for defying the order, 2,000 congregated at a protest meeting in Christchurch. The crowd asserted its solidarity with the dismissed men, but the ASRS allowed the railways to remain operational. By quickly hiring non-union workers, the Union Company decisively warded off the labour threat. ${ }^{47}$ On 24 September, the line announced that 34 of its 43 steamers had resumed service, crewed and loaded by over 2,000 non-union men. ${ }^{48}$

Sensing defeat, union leaders sought to negotiate a settlement. Although Premier Atkinson declined to intervene in the dispute at a meeting with the Maritime Council executive on 1 September, when the Opposition MHR (Member of the House of Representatives) W.B. Perceval moved that the government convene a conference to mediate the dispute on 15 September, the House carried his motion 51 to $11 .^{49}$ From 30 September, Perceval sought to bring labour leaders alongside the colony's largest

\footnotetext{
${ }^{44}$ Nolan, Kin, p.58; Roth, Trade Unions in New Zealand, p.14; Svensen, The Sinews of War, p.xi.

${ }^{45}$ Merrett, 'A Reappraisal of the 1890 Maritime Strike', pp.83-86, 106.

${ }^{46}$ Nolan, Kin, p.58.

${ }^{47}$ Merrett, 'A Reappraisal of the 1890 Maritime Strike', pp.88-92.

${ }^{48} L T, 24$ September 1890, p.5.

49 'Deputation to the Honble the Premier: $1^{\text {st }}$ September 1890', in Guy H. Scholefield (ed.), The Richmond - Atkinson Papers, Vol. 2, Wellington: Government Printer, 1960, pp.559-64; New Zealand Parliamentary Debates [NZPD], 1890, Vol. 69, p.907.
} 
employers. Yet, foreshadowing the failure of negotiation, only George McLean of the Union Company represented capital at the conference. Unwilling to concede any ground to the defeated unionists, McLean precipitated the collapse of the meeting. On 8 October, the Maritime Council instructed all shore unions, aside from the South Island miners, to return to work, while encouraging the remainder of its members to resist until the negotiation of an acceptable settlement. ${ }^{50}$ The order was futile. The unionists held out for another month, but their efforts neither influenced the public nor their former employers. The strike ended on 10 November, marked only by a notice posted outside the Maritime Council's offices stating, 'members of the Seamen's Union were at liberty to rejoin their boats'. ${ }^{51}$ Mass industrial agitation had failed; if organised labour were to realise lasting social and economic reform, it would have to occur via the ballot box.

\section{The Maritime Strike in New Zealand Newspapers:}

The New Zealand press reacted slowly to the Australian strike. It was only between 18 and 21 August, three weeks after the dispute began, that all six newspapers discussed in this thesis began publishing designated columns on the dispute. As with general labour columns, the headlines attached to these pieces revealed something of a newspaper's stance on the strike - while most papers reported on the Australian 'Strike' or 'Trouble', the Press consistently referred to 'The Labor War in Australia'. ${ }^{52}$ Although news of the Australian situation quickly reached New Zealand, editors took time to formulate responses to the strike. An exception, the New Zealand Herald published an even-handed summary of the Australian strike on 20 August.

\footnotetext{
${ }^{50}$ Press, 10 October 1890, p.4.

${ }^{51}$ ODT, 11 November 1890, p.2.

${ }^{52}$ Press, 21 August 1890, p.5.
} 
The paper lamented the 'very considerable [economic] inconvenience' inflicted by the strike, yet did not foresee its extension across the Tasman. ${ }^{53}$

By the time the SSOA Conference opened on 23 August, the Australian Maritime Strike was a major story in New Zealand newspapers. All six papers reported the owners' unanimous resolution that: 'no officer shall be given command of a vessel if he was connected with any association affiliated to any labour organisation' ${ }^{54}$ The Union Company's membership of the SSOA was widely publicised, yet the press ignored the meeting's ramifications for domestic industrial relations. A lone exception, the Lyttelton Times ran an editorial on 27 August castigating the shipowners' perfidy. William Pember Reeves believed that the Albury resolution constituted an attack on trade unions. With food prices rising, the decision to retain all non-unionised workers hired during the dispute amounted to a naked display of hostility. Furthermore, Reeves implicated the press in the 'conspiracy' against trade unionism. Contesting the dominant framing of strike stories, he identified the prevalence of the phrase 'free labour' as suggestive of a false struggle between 'organisation and individual liberty'. New Zealand newspapers not only reproduced the phrase in UPA reports from Australia, but it regularly featured in domestic journalism. ${ }^{55}$ By replicating employers' emphasis on 'freedom', newspapers implied that trade unions discouraged independence and self-reliance. ${ }^{56}$

In the days following the Tarawera incident, both the Maritime Council and the Union Company released competing 'manifestos', seeking to manipulate public perceptions of the strike. Published widely on 28 August, the Union Company's statement boasted of its fair wages, amenable working environment, and history of

\footnotetext{
${ }^{53} \mathrm{NZH}, 20$ August 1890, p.4.

${ }^{54} E P, 25$ August 1890, p.2.

${ }^{55}$ See for example $E P, 29$ August 1890, p.2; EP, 6 September 1890, p.2; NZH, 29 August 1890, p.5; $O D T, 6$ September 1890, p.2; Press, 30 August 1890, p.5.

${ }^{56}$ LT, 27 August 1890, p.4.
} 
industrial amity. Thus, blame for the 'imminent paralysis of trade in all the colonies' lay with the 'Labour Union of all Australasia'. ${ }^{57}$ Conspicuously absent from the announcement was the company's complicity in the Albury declaration. The Union Company had, as the Otago Daily Times noted, 'unhesitatingly throw[n] the whole responsibility of the very serious disorganisation...upon the shoulders of the leaders of the unions' ${ }^{58}$ Released the next day, the Maritime Council's response reached a slightly smaller audience, published in all newspapers except the Press. The Council denied seeking a 'trial of strength', emphasising that as a SSOA member, the Union Company had conspired to challenge a fundamental principle of trade unionism. Furthermore, the company had employed 'blacklegs' at its Sydney wharves despite the FSU's promise to maintain inter-colonial services. Only after these egregious provocations was 'the Union forced to take action'. ${ }^{59}$

William Pember Reeves' criticism of the complicity between capitalists and the press remained unique when the strike reached New Zealand ports. ${ }^{60}$ In addition to ignoring the Maritime Council's account of the dispute, most newspapers uncritically reproduced the Union Company's manifesto. The New Zealand Herald believed that the strike demonstrated the dangers posed by inter-colonial labour federation. If asked why they left work, the Herald pre-empted the maritime workers' reply: 'We are called out from Sydney by...an organisation we cannot disobey,. ${ }^{61}$ On 28 August, the Press reached a similar conclusion, warning the Maritime Council that the public would hold it accountable for an industrial 'standstill' and 'coal famine...in the midst of actual plenty'. 'Perfectly satisfied' that labour had no quarrel with the Union Company, the paper believed that the Council's strike order had 'alienated the last

\footnotetext{
${ }^{57}$ GRA, 28 August 1890, p.2.

${ }^{58}$ ODT, 27 August 1890, p.2.

${ }^{59}$ GRA, 29 August 1890, p.2.

${ }^{60}$ However, the first two issues of Arthur Desmond's labour paper, the Tribune, reiterated Reeves' concerns about the term 'free labour'. Tribune, 18 October 1890, p.1; Tribune, 25 October 1890, p.1.

${ }^{61}$ NZH, 27 August 1890, p.4.
} 
vestige of public sympathy [for organised labour] ${ }^{62}$ Weighing in the following day, the Otago Daily Times unequivocally apportioned blame for the strike: 'It is...madness for New Zealand seamen to be compelled by an Australian command to leave an employment with which they have every reason to be satisfied'. By contrast, the editorial absolved the Union Company from accountability in the unfolding 'war between labour and capital' ${ }^{63}$ Mirroring the Union Company's official statement, all three editorials ignored the ship-owners' attack on trade unionism at Albury.

Unfortunately for John Millar, providing a convincing justification for the New Zealand strike proved difficult. The Maritime Council was embroiled in what the public considered an Australian dispute. At issue were not wages or working conditions, the staples of industrial ferment, but the defence of principles fundamental to new unionism, a movement most New Zealanders barely understood. ${ }^{64}$ As Florence McCarthy noted during the Grey Valley lockout, organised labour remained severely deficient in public communications. While the conservative press framed the dispute as a product of inter-colonial solidarity, greed, and radical ideology, the few 'allies' of labour in the press mounted a weak and incoherent defence of the strike. In its first editorial on the strike on 1 September, the Grey River Argus sought to reframe the strike as a defensive response to capitalist aggression. Asking, 'is boycotting any worse than monopoly?' the paper compared the public 'howl of indignation' directed at the strikers with consumers' meek acceptance of the Union Company's immediate increase in shipping rates. Furthermore, the Argus was the only newspaper to link the Union Company's enforcement of the Albury resolution with the outbreak of a New Zealand strike. Arguing that the strike demonstrated the fallacy of 'moderate' unionism, the paper highlighted the vast

\footnotetext{
${ }^{62}$ Press, 28 August 1890, p.4.

${ }^{63}$ ODT, 29 August 1890, p.2.

${ }^{64}$ Gardner, Prelude to Arbitration, p.116.
} 
power imbalance between labour and capital that allowed the ship-owners to 'starve the men out', rather than consider their grievances. ${ }^{65}$

While the Grey River Argus portrayed the Union Company as a ruthless behemoth, the remainder of the liberal press eschewed such advocacy. In its first editorial on the New Zealand strike, published on 2 September, the Lyttelton Times ignored the origins of the strike, and instead praised the picketing workers' 'admirable demeanour'. Adapting the 'social norms' frame, the paper held that a demonstration of exemplary behaviour by the strikers would engender public sympathy. To avoid jeopardising the aims of trade unionism - the moral and material elevation of the working classes - the paper urged workers to protest in such a manner 'that their opponents are forced to respect them' ${ }^{66}$ Meanwhile, the Evening Post expressed hopes of a rapid resolution to the strike, arguing that both sides had expressed 'a desire for pacific adjustment of the difficulty'. The Post assiduously avoided the strike's origins, devoting its attention to the structure of an eventual reconciliation. Worried that grandstanding politicians would hijack the arbitration process, the Post mooted Churchill Julius, the Anglican Bishop of Christchurch, as a potential mediator. ${ }^{67}$ Although neither paper condemned the striking workers, nor did they examine the grievances that precipitated and sustained the dispute.

The dire predictions that filled editorial columns were not supported by accurate information regarding the number of workers on strike. Daily news coverage rarely featured reliable data on the strikers. Where quoted, numbers had a rhetorical value round, obviously estimated figures, congruent with public expectations but frequently contradicted by later estimations. Discrepancies in the reported number of strikers in Wellington during September emphasise the unreliability of these estimates. On 1

\footnotetext{
${ }^{65}$ GRA, 1 September 1890 , p.2.

${ }^{66} L T, 2$ September 1890, p.4.

${ }^{67}$ EP, 2 September 1890, p.2.
} 
September, it was widely reported that 400 men had left work, a number quadrupled by the New Zealand Herald within four days. ${ }^{68}$ Three weeks later, when the strike had begun to wane, the Evening Post reported that 500 men remained out. ${ }^{69}$ While not impossible, the sudden leap between 1 and 5 September does not correspond with any reported intensification of the Wellington strike. Reports seldom included figures for other centres, but the rare exceptions were also unreliable. On 8 September, the Otago Daily Times noted that 1,500 of 8,000 workers affiliated with the Auckland TLC had joined the strike. ${ }^{70}$ In an era when trade unionism was strongest in the South Island, the suggestion that nearly half of the colony's 21,000 organised workers lived in Auckland was implausible. Exaggerating the strike's impact, newspaper editors ignored the reality that less than four per cent of wage earners participated in the strike - hardly an overwhelming menace. ${ }^{71}$

\begin{tabular}{|l|l|l|l|}
\hline City & Number on Strike & Paper & Date \\
\hline Auckland & 1,500 (of 8,000 TLC affiliates) & Otago Daily Times, p.2. & $8 / 9 / 1890$ \\
\hline Auckland & 1,500 & Evening Post, p. 2. & $8 / 9 / 1890$ \\
\hline Wellington & 400 & Grey River Argus, p.2. & $1 / 9 / 1890$ \\
\hline Wellington & 400 & Otago Daily Times, p.2. & $1 / 9 / 1890$ \\
\hline Wellington & 400 & Press, p.5. & $1 / 9 / 1890$ \\
\hline Wellington & 1,500 & New Zealand Herald, p.5. & $5 / 9 / 1890$ \\
\hline Wellington & 500 & Evening Post, p.2. & $26 / 9 / 1890$ \\
\hline Wellington & 500 & Otago Daily Times, p.2. & $27 / 9 / 1890$ \\
\hline Christchurch & 800 & Lyttelton Times, p.4. & $3 / 9 / 1890$ \\
\hline Greymouth & 600 & Evening Post, p.2. & $25 / 9 / 1890$ \\
\hline
\end{tabular}

Table One: Newspapers' estimates of the number of workers on strike, September 1890.

As their estimates testify, the press exaggerated the impact of the strike. Newspaper reports depicted a society paralysed by the suspension of vital costal shipping routes. In reality, the strike's impact on the colony varied regionally.

\footnotetext{
${ }^{68}$ Press, 1 September 1890, p.5; NZH, 5 September 1890, p.5.

${ }^{69} E P, 25$ September 1890, p.4.

${ }^{70}$ ODT, 6 September 1890, p.2.

${ }^{71}$ Eldred-Grigg, New Zealand Working People, p.21.
} 
Although the Maritime Council had ordered out seamen working inter-colonial routes on 25 August, domestic services continued until the Wairarapa sailed on 28 August. Even then, John Millar's strike order was not enacted smoothly, not least because crews could not be withdrawn mid-voyage. ${ }^{72}$ Although the Maritime Council aspired to represent all workers, regional unions decided whether their members followed Millar's instructions. Thus, the strike began in an ad hoc fashion. After the initial confusion, Dunedin seamen and dockers left work on 28 August, and their Christchurch counterparts walked off the Lyttelton wharves on the afternoon of 29 August. $^{73}$ On the same day, the Evening Post remarked: 'Although the strike practically commenced in Wellington today, there was nothing to be seen'. ${ }^{74}$ In Auckland, where the Union Company had few employees, shipping continued largely unhindered until the Northern Company transported non-union crews on 5 September. Within two days, the company's entire fleet was stranded in port. ${ }^{75}$

Although its offices were distant from the epicentres of the strike, the New Zealand Herald established itself as the Maritime Council's most vituperative critic. In a hysterical editorial published on 2 September, the paper reiterated the case for organised labour's absolute culpability in the dispute. Declaring the colony 'perilously near' to civil war, the Herald demanded government intervention 'to prevent hundreds from perishing'. Public opinion was deemed unfavourable to the strikers 'for the simple reason that they have no substantial grievance to complain of' ${ }^{76}$ The previous day, the Press had also expounded upon the absence of a 'just' cause for the strike, aside from the 'quarrel between the ship owners in Australia and their officers'. Dismissing the question of affiliation, the paper defended the Albury

\footnotetext{
${ }^{72}$ McLean, The Southern Octopus, p.110.

${ }^{73}$ LT, 29 August 1890, p.6.

${ }^{74} E P, 29$ August 1890, p.2.

${ }_{76}^{75}$ Atkinson, 'Against the Tide', in Walsh (ed.), Trade Unions, Work and Society, p.77.

${ }^{76} \mathrm{NZH}, 2$ September 1890, p.4.
} 
resolution, arguing that any workers' 'alliance for offence and defence' subverted discipline. The results of such alliances were clear: the Maritime Council had 'ruthlessly sacrificed' the interests of the colony in favour of supporting their Australian comrades. ${ }^{77}$ Central to the Press' scorn for the Maritime Council was the organisation's purported secrecy; the paper depicted the leadership as a shadowy cabal of troublemakers. Unsurprisingly, the SSOA escaped similar scrutiny. Again, critics exploited the ideological basis of the strike, calculating that abstruse union principles would not resonate with the public.

After the initial shock had subsided, newspaper editors vacillated between exaggerating the consequences of a nationwide strike, and simultaneously reporting the Maritime Council's inability to maintain an embargo on domestic transportation. The disjuncture between editorial demagoguery and daily reportage on the strike is revealing. Apparently unaware of the irony, on the day that its editorial warned of an impending civil war, the New Zealand Herald reported, 'there has been no very noticeable outward effect upon trade [in Auckland] up to the present time'. ${ }^{78}$ The next day, the paper described the situation across the colony as 'all quiet'. ${ }^{79}$ Similarly, while the Press lamented the economic damage wrought by the strike, it reported that work at the Lyttelton wharves was 'proceeding most satisfactorily' ${ }^{80}$

Although the first 48 hours of the strike paralysed domestic shipping, a loose alliance of farmers, capitalists, and shipping companies quickly organised makeshift crews and replacement labourers. Unemployment peaked at the end of winter, leaving an abundance of men desperate for work in September. ${ }^{81}$ Middle-class volunteers 'men of independent means, members of athletic clubs, bank clerks, schoolmasters,

\footnotetext{
${ }^{77}$ Press, 1 September 1890, p.4.

${ }^{78} \mathrm{NZH}, 2$ September 1890 , p.5.

${ }^{79}$ NZH, 3 September 1890 , p.5.

${ }^{80}$ Press, 1 September 1890 , p.5.

${ }^{81}$ Merrett, 'A Reappraisal of the 1890 Maritime Strike', pp.107-08.
} 
etc' - united by their distrust of trade unionism, supplemented non-union labour. ${ }^{82}$ On 30 August, the day after the Lyttelton strike began, the $12.10 \mathrm{pm}$ train left Christchurch carrying 300 rural labourers. The 'young farmers', coordinated by Press owner George Stead, unloaded the Tekapo (losing 15 tons of coal overboard), and later in the afternoon, the Rotorua left Lyttelton manned by a non-union crew. ${ }^{83}$ By early September members of the Otago Rowing Club and Union Company clerks worked the docks at Port Chalmers. ${ }^{84}$ Reporting from Auckland on 30 August, the New Zealand Herald claimed that enough 'free' labour had assembled to 'furnish a crew of competent men' to operate a large steamer. The following week, the Herald noted that a 'dozen gentlemen' and '40 athletic young fellows from the Auckland Rowing Club' assisted the unloading of docked vessels. ${ }^{85}$ Middle-class support allowed the Union Company to resume selected routes on 5 September. ${ }^{86}$

While the press generally represented the Maritime Strike as an example of the dangers inherent in labour federation, the advent of employer mobilisation was received warmly. On 3 September, a group of Otago businessmen met at the Dunedin Chamber of Commerce to form an organisation that secured its members 'all the advantages of unanimity of action now enjoyed by the various trade unions' ${ }^{87}$ The Press pre-empted the meeting by publishing an advertisement encouraging employer solidarity. Entitled 'Advance New Zealand!' the article detailed the structure of an ambitious colony-wide employers' union. ${ }^{88}$ Within a week, Employers' Associations were established in the four main centres, as well as provincial towns across the

\footnotetext{
${ }^{82}$ W.T. Charlewood, 'Labour Troubles in New Zealand', The Economic Journal, Vol. 1, no. 4, December 1891, p.713.

${ }^{83}$ In addition to Stead's organisational support, his paper published advertisements instructing farmers to 'consider the position as affecting their interests', and assist strikebreaking efforts. Press, 30 August 1890, p.4; EP, 30 August 1890, p.2; LT, 30 August 190, p.6.

${ }^{84} O D T, 1$ September 1890, p.2; ODT, 4 September 1890, p.2.

${ }^{85}$ NZH, 1 September 1890, p.5; NZH, 3 September 1890, p.5.

${ }^{86} \mathrm{NZH}, 5$ September 1890 , p. 1.

${ }^{87}$ Otago Witness, 4 September 1890, p.19.

${ }^{88}$ Press, 26 August 1890, p.8.
} 
colony. ${ }^{89}$ The new associations were autonomous, but together formed a rough coalition. Commenting on these associations, the Press was bellicose, noting, ' $\mathrm{Mr}$ Millar and his colleagues have declared Canterbury in a state of siege' leaving employers with 'no alternative but to organise' ${ }^{90}$ Revealing the common ground between the liberal and conservative press, the Lyttelton Times also supported the employers' associations, noting that federated labour had 'set a model of moderation' that capitalists would benefit from emulating. So long as the employers refrained from 'bitter speeches and defiant challenges', the paper believed the development would encourage dispute resolution. ${ }^{91}$

The difference in frames applied to violent incidents related to the strike, depending on the perpetrator's allegiance, illuminates the anti-labour biases shared by liberal and conservative newspapers. Although contemporaries lauded the relative amity of the Maritime Strike, animosity between unionists and non-union labour occasionally flared into fighting. When strikers instigated violence, newspapers adopted a tone of haughty condemnation. On 17 September, the Lyttelton Times devoted an entire page to a story on 'The Wilson's Road Outrage'. ${ }^{92}$ The 'outrage' a brawl between 'free' and unionised labour in the Christchurch suburbs - occurred on 8 September, and District Court hearings began the following week. Although nine of the ten accused were acquitted on grounds of self-defence, other newspapers also referred to the confrontation as the 'Wilson's Road Outrage', or 'The Christchurch Outrage' - headlines that implied an exaggerated propensity to violence amid the union ranks. ${ }^{93}$ In the same vein, Press titled a report on a minor confrontation between unionists and farm labourers, 'Rioting At Dunedin'. Picketing

\footnotetext{
${ }^{89}$ See Appendix One for details on the formation of Employers' Associations across New Zealand.

${ }^{90}$ Press, 6 September 1890, p.4.

${ }^{91} L T, 5$ September 1890, p.4.

${ }^{92} L T, 17$ September 1890, p.8.

${ }^{93} E P, 17$ September 1890, p.2; GRA, 17 September 1890, p.4.
} 
unionists were described as a crowd of 'larrikins...ready for mischief', yet the 'riot' failed to escalate beyond stone throwing. A week later, under the headline 'Free Labourers Attacked', the paper described how the orderly nature of the Lyttelton strike was shattered by the ambush of a non-union labour gang, perpetrated by 'members of the Wharf Labourers' Union and the Seamen's Union'. 94

Yet, when trade unionists were the victims, the press responded in a more conciliatory fashion. On 12 September, Robert Allan, a non-union labourer, was arrested after assaulting William Gerrard, a Wellington unionist. Pushed by Allan during an argument, Gerrard fell into the hold of the Australia, fracturing several ribs and vertebrae - leaving him a paraplegic. However, the Press excused the incident as 'An Unfortunate Occurrence'. ${ }^{95}$ The Evening Post also trivialised the story, publishing it under the headline 'Mishap Aboard The Australia'.96 Although Gerrard's injuries were life threatening, in following days the Press headlined the story 'An Unfortunate Fracas', while simultaneously reporting violence against 'free' labour under the rubrics 'The Free Labor Assaults', and 'Brutal Assault'. ${ }^{97}$ The difference in tone between crime reports, based on the identity of the perpetrator, clearly demonstrated where newspapers' sympathies lay, and with whom they wanted readers to identify.

\section{Those 'Irresponsible Men' - The Railway Commissioners Curtail the Strike:}

The faltering intrusion of the railwaymen into the Maritime Strike further polarised public discourse, forcing editors to address the consequences of the Railway Commissioners' reprisal - the first state intervention in the dispute. Chastened by the

\footnotetext{
${ }^{94}$ Press, 9 September 1890, p.5.

${ }^{95}$ Press, 12 September 1890, p.6.

${ }^{96} \mathrm{EP}, 12$ September 1890, p.2.

${ }^{97}$ Press, 12 September 1890, p.6; Press, 13 September 1890, p.5; Press, 20 September 1890, p.6. See also Svensen, The Sinews of War, p.170.
} 
Whitcombe and Tombs affair, the railwaymen remained at work on 28 August. Confident that their coal reserves would outlast the strike and in command of one of the few large, well-organised workforces in the colony, the Commissioners' recognised an opportunity to curtail the strike. ${ }^{98}$ At Westport and Lyttelton, managers ordered railway workers to handle goods normally unloaded by dockers. The men refused to serve as strike-breakers, and by 3 September, the Railways Department had suspended 61 workers in Westport and 150 in Lyttelton. Escalating the standoff, on 9 September the Commissioners dismissed the president, vice president, and two members of the ASRS after they refused to cease their activism. Outraged Opposition MHRs decried the intervention as an attempt to crush the union. Opposition leader John Ballance demanded an explanation, noting the 'remarkable revulsion of public feeling' at the misuse of power by such 'irresponsible men'. ${ }^{99}$ Workers expressed their indignation at rallies in Christchurch on 3 and 11 September, but resolved only to censure the Commissioners' conduct. Meanwhile, ASRS members continued operating passenger and freight services. Indifferent to public opprobrium, the Commissioners upheld their controversial decisions, issuing a statement on 6 September advising employees who had 'recklessly and foolishly' disobeyed orders to 'give notice in a proper and orderly manner and resign their places'. ${ }^{100}$

The prospect of the strike spreading to include government employees prompted the Evening Post to turn against organised labour. Until the dismissal of the ASRS leadership, the paper confined its analysis of the strike to platitudes on the virtues of mediation. However, on 11 September, the Post commended the Commissioners' decision, noting that 'a service of railways could not be carried on efficiently if such

\footnotetext{
${ }^{98}$ Merrett, 'A Reappraisal of the 1890 Maritime Strike', pp.95-96.

${ }^{99}$ NZPD, 1890, Vol. 69, pp.699, 813.

100 'Railway Employés: Letter from the Railway Commissioners Regarding the Dismissal of Four', AJHR, 1890, H-44, pp.1-2.
} 
insubordination...was permitted to pass unnoticed'. Siding with the Atkinson Government's argument that civil servants 'cannot serve two masters', the Post believed that Ballance had made a 'fatal tactical mistake' in appropriating the matter for political advancement. ${ }^{101}$ The Press, another prominent supporter of the Commissioners, declared the dismissals an unavoidable consequence of the railwaymens' disobedience. The paper believed that the incident demonstrated the dangers of a powerful railways union - it 'encourage[d] the men to disobey the rules of service'. Furthermore, the Press used the opportunity to attack the union's leadership, accusing it of adopting the Maritime Council's 'false position' and subsequently encouraging 'a spirit of insubordination' amongst railway workers. ${ }^{102}$

Congruent with the debate's political cleavage, on 15 September the Lyttelton Times published an impassioned defence of the dismissed railwaymen. Three days earlier, William Pember Reeves grilled Acting-Premier Edwin Mitchelson in the House, demanding an explanation from the Railway Commissioners. ${ }^{103}$ In his editorial, Reeves explained why the 'despotic' Commissioners had 'endeavour[ed] to destroy' the ASRS just months after they had officially recognised the union. He argued that they had followed a 'Russian policy' during the June negotiations swallowing unpalatable demands while preparing to marginalise the union in a future period of strength. Reeves' sympathies undoubtedly rested with the dismissed workers, yet in light of the forthcoming election he was eager to tar the government with the scandal. Utilising his editorial platform, Reeves argued that the Railway Commissioners had silenced free speech and 'squelch[ed] Unionism' to ingratiate themselves with 'a Conservative and capital representing government' ${ }^{104}$

\footnotetext{
${ }^{101}$ NZPD, 1890, Vol. 69, p.808; EP, 11 September 1890, p.2.

${ }^{102}$ Press, 11 September 1890, p.5.

${ }^{103}$ NZPD, 1890, Vol. 69, pp.798-829.

${ }^{104} L T, 15$ September 1890, p.4.
} 
In the aftermath of the railways controversy, newspapers displayed an increasing hostility toward labour leaders. The deposition of the ASRS leadership coincided with the Australian arrival of the British 'socialist' Henry Hyde Champion. Described as 'a Tory at heart', Champion arrived in Australia on 12 August, intending to study the labour movement, but grew frustrated with colonial unionists' failure to recognise his ability and install him as leader. ${ }^{105}$ Australian distrust of Champion was mirrored in England, where contemporaries considered him a gentleman intriguer, tainted by allegations that he spent 'Tory gold' to split the liberal vote in $1885 .{ }^{106}$ Despite his ignorance of local conditions, Champion entered the debate over the Maritime Strike. On 6 September he wrote an article for the Melbourne Age proposing a series of concessions necessary for labour to reach a palatable compromise. After establishing his trade union credentials, Champion argued for the abandonment of the 'closed shop', asserting that he could 'hardly believe any responsible trade unionist' would refuse to work alongside non-union labour. In a section on intimidation Champion argued that trade unionists needed to court the widest possible segment of the public: a path requiring the rejection of violence. The point was apposite, yet undermined by his failure to address instances of state and employer coercion. Champion concluded with a final slight to Australian labour, asserting that capitalists had no qualms with trade unions, they merely objected to their 'arbitrary and unfair' negotiating tactics. ${ }^{107}$

Champion's piece was understandably popular amongst Australasian capitalists. The Age reported that prominent employers had 'expressed themselves in sympathy with the views expressed in the article', while Whitcombe and Tombs printed a poster summarising Champion's opinions, entitled 'A Labour Delegate's Views', at the

\footnotetext{
${ }^{105}$ Svensen, The Sinews of War, p.156.

106 Jacqueline Dickenson, "The Greatest Curse and Traitor': H.H. Champion and the Australian Labour Movement', Journal of Australian Studies, no. 80, 2004, p.189.

${ }^{107}$ Age, 6 September 1890, no page, in Jacqueline Dickenson, Renegades and Rats: Betrayal and the Remaking of Radical Organisations in Britain and Australia, Melbourne: Melbourne University Press, 2006, pp.59-60.
} 
behest of a group of employers. ${ }^{108}$ Although New Zealand unionists considered Champion a 'renegade', the press largely supported his programme for industrial harmony. ${ }^{109}$ The Press approvingly described his article as 'the severest rebuke which has yet been administered to the organisers of the present strike'. Disingenuously summarising the piece, the paper commended Champion's 'advice' for the marine officers to sever their connections with 'Trades Hall', approach the SSOA and 'trust to their honor [sic] to treating them fairly'. ${ }^{110}$ Supporting their editorial, the Press published Champion's article on 19 September, two days after it appeared in the Otago Daily Times. ${ }^{111}$ On 23 September, both the Evening Post and Grey River Argus published the article in its entirety, prefaced by a note establishing Champion's metropolitan labour credentials as a 'delegate from the English Trades Congress'. ${ }^{112}$

Champion's opening salvo against labour leaders precipitated renewed criticism of the Maritime Council executive in the press. Following the mould established by the New Zealand Herald in its May identification of 'professional agitators' as the progenitors of industrial disharmony, these attacks were grounded in the rhetoric of colonial consensus. Situating themselves as guardians of social order, newspaper editors sought to both extinguish any remaining public sympathy for labour's figureheads and marginalise the intellectual and organisational leadership of a feared class movement. On 12 September, the New Zealand Herald ignored the Maritime Council's manifesto, declaring that the strike's leaders had 'failed to give any reasons for their action that would weigh with intelligent and impartial men'. Instead, they surveyed their mayhem with 'gloomy satisfaction'. ${ }^{113}$ The next day, the Otago Daily

\footnotetext{
108 ibid., p.60; Svensen, The Sinews of War, p.157.

109 'Labour Conference: Held at Wellington, October, 1890 (Report of the Proceedings)', AJHR, 1891, Session 1, H-1, p.28.

${ }_{111}^{110}$ Press, 10 September 1890, p.4.

${ }^{111}$ Press 19 September 1890, p.4; ODT, 17 September 1890, p.4.

${ }_{112}$ EP, 23 September 1890, p.4; GRA, 23 September 1890, p.4.

${ }^{113} \mathrm{NZH}, 12$ September 1890, p.5.
} 
Times asked 'what is it, precisely, that is aimed at by continuing the strike?' Aside from the initial disruption on 29 August, the paper considered the strike an abject failure and reminded John Millar of his duty to end the strike, if only to prevent further suffering amongst the union rank and file. ${ }^{114}$ The most strident criticism came from the Press, which boldly claimed that 'the Leaders of the Unions are mainly responsible for what has come on the colony'. If workers had not ceded their autonomy to 'self-appointed agitators', the strike would not have occurred. Instead, the colony faced the 'virtual destruction of the majority of local industries' and a future stifled by 'the autocratic rule of the Maritime Council'. ${ }^{115}$

In a climate hostile to organised labour, it was remarkable that unionists enjoyed the support of one of New Zealand's largest newspapers, the Lyttelton Times. While the conservative press hounded labour leaders, the Times remained an ardent defender of trade unionism. In an editorial that reaffirmed the necessity of the labour movement, the paper remarked that the 'touchstone of adversity' had divested workers of their fair-weather friends. The 'Tory organs of the Press from Auckland to Invercargill' had shown their true colours by tacitly supporting 'a determined effort...to crush all Unions'. ${ }^{116}$ The chief target of William Pember Reeves' ire was the Otago Daily Times - for its perceived betrayal of the labour movement. When the Daily Times used its editorial column to criticise Christchurch Bishop Churchill Julius, for delivering a 'purely imaginary' sermon on 'the tyranny and selfishness of capitalists who grind the faces of the poor', the Lyttelton Times responded in kind. ${ }^{117}$ On 7 October, the paper's editorial expressed surprise that the Daily Times had 'gone over bodily to the enemy's camp', despite its 'sweating' investigations and support

${ }^{114}$ ODT, 13 September 1890, p.2.

${ }^{115}$ Press, 13 September 1890, p.4.

${ }^{116} L T, 19$ September 1890, p.4.

${ }^{117}$ ODT, 4 October 1890, p.2. 
for the formation of a Tailoresses' Union in 1889. If these problems were 'purely imaginary', why had Daily Times editor George Fenwick previously acknowledged their existence? Reeves accused the paper of distorting an 'eloquent call for peace' as an attack on capitalism. ${ }^{118}$ Fenwick's terse reply came on 13 October, when he branded the Lyttelton Times' defence of Julius as 'spiteful, acrimonious, discourteous and untrue'. He acknowledged his paper's previous support of trade unionism but defended the Daily Times' new stance as a reaction to the 'false track' taken by a 'badly advised and badly led' movement - only an enemy of labour would abide its leaders' mistakes. ${ }^{119}$

While the metropolitan dailies contested the causes, magnitude, and possible solutions to the Maritime Strike, the pro-labour Grey River Argus maintained a local focus. The paper's predominant concern was the impact of the strike on the West Coast economy, perilously reliant on the turbulent mining industry. The fragile truce that allowed the mines to reopen following the Grey Valley lockout lasted just three weeks. On 28 August, the Denniston miners threatened to strike if the WCC continued to supply Union Company vessels. The company ignored the ultimatum, eager to secure 'large reductions in wages and to bring the Union to reason', and the Denniston mine closed on 3 September. ${ }^{120}$ Three weeks later, the neighbouring Grey Valley miners ceased work when the GVCC violated an agreement not to refuel Union Company steamers. ${ }^{121}$ Despite widespread public concerns about fuel shortages, news from the region rarely featured in the press, yet its relatively small labour force exaggerated the impact of the shipping boycott. While employers in the

\footnotetext{
${ }^{118} L T, 7$ October 1890, p.4.

${ }^{119}$ ODT, 13 October $1890, \mathrm{p} .2$

${ }^{120}$ Charles Holdsworth (Union Company representative) to George McLean, 6 September 1890, in Richardson, Coal, Class and Community, p.45.

${ }^{121}$ Richardson, Coal, Class and Community, pp.44-45.
} 
main centres quickly organised replacement workers, the threadbare non-union gangs in Greymouth were only unloading one ship per day by mid-September. ${ }^{122}$

However, in late September the Grey River Argus recognised the arrival of 'strange policemen' in concert with the swearing in of 75 local 'specials' as indications that the 'peaceful character' of the dispute had ended. ${ }^{123}$ Justifying the paper's fears, the following day the hastily assembled constabulary struggled to restrain an angry crowd of unionists from disrupting the loading of the Brunner with coal at Greymouth. The day's events offered scope for a story sensationalising the strikers' rowdy conduct, yet the Argus published a comprehensive summary of the arguments advanced by unionists at a rally two days later. The story, 'Mass Meeting At Victoria Park', spanned two pages, as the paper rejected the consensus myth in favour of reporting the miners' grievances. ${ }^{124}$ Consistent with its aim of representing labour fairly, on 30 September the Argus re-examined the strike's origins, explicitly situating the Maritime Council's intervention as a defensive response to employer aggression. Compiling statements from prominent figures on both sides, the paper assembled a narrative indicting Australasian ship-owners for deliberately provoking organised labour. Concluding the article, the Argus reporter challenged 'anyone who has made himself acquainted with the facts and incidents of the dispute to say the Maritime Council recklessly and thoughtlessly rushed into this trouble'. ${ }^{25}$

While the Grey River Argus strove to correct the distorted public image of the labour movement, it remained an organ for pragmatic reporting. By early October, the miners were in disarray. Food and money ran out, hardships barely alleviated by the meagre $£ 200$ the West Coast unions received from the Maritime Council's Strike

${ }^{122}$ GRA, 17 September 1890, p.2.

${ }^{123}$ GRA, 22 September 1890, p.2.

${ }^{124}$ GRA, 25 September 1890, pp.2, 4 .

${ }^{125}$ GRA, 30 September 1890, p.2. 
Defence Fund. ${ }^{126}$ Initial hopes that labour shortages would force employers to negotiate were dashed on 3 October, when the Argus reported that 150 free labourers had arrived to reopen the Denniston mine. The paper believed the development demonstrated that, having 'overcome the first inconvenience', capitalists had time on their side. Now that non-union labour had reached even the remotest of West Coast mines, the Argus urged the Maritime Council to consider whether 'they are in such a position as will reasonably warrant them still holding out, or whether it would not be more prudent to effect a compromise before it becomes too late altogether'. ${ }^{127}$ The warning was prescient; by 31 October, 200 men - one third of the picketing miners had reapplied for work, further weakening their comrades' situation. ${ }^{128}$ Unionism had no place in the new order. After accepting sharp wage cuts, the 80 successful applicants entered employment stripped of their union protection and customary privileges. $^{129}$

As management ruthlessly exploited the miners' two former strengths - their remoteness and tight organisation - news coverage of the strike rapidly dwindled. In late August, aggregated reporting on the strike filled around a page in the average metropolitan daily. Yet, after the initial shock and excitement dissipated, the quantity of reporting on the strike steadily decreased. In areas least affected by the strike, this process occurred rapidly: by mid-September the New Zealand Herald had reduced its strike coverage to just two columns, and a week later it was no longer a daily feature in the newspaper. The transition was more pronounced in the Grey River Argus, which reduced almost a page of strike news on 1 September to half a column by the end of the month. In cities with large populations of trade unionists - Wellington,

\footnotetext{
126 'Balance-Sheet of the Strike Defence Fund: from September 1, 1890 to January 26, 1891', 18901891, Roth Papers, MS-Papers 94-106-29/04, ATL.

${ }^{127}$ GRA, 3 October 1890 , p.2.

${ }^{128}$ GRA, 31 October 1890, p.2.

${ }^{129}$ Richardson, Coal, Class and Community, p.49.
} 
Christchurch, and Dunedin - the strike remained topical into October, although by the middle of the month most newspapers reduced their daily coverage to less than half a column

\section{A Sincerity Gap? Expectations and Outcomes of the Labour Conference:}

Although the strike stagnated, both on the wharves and in the press, fresh developments still elicited newspaper reportage and commentary. By late September, the forthcoming Labour Conference overshadowed reporting on the pickets. Announced on 16 September, the conference was intended to broker an end to the strike. The press responded cynically to the proposal, and few thought that it would succeed. The Evening Post held little hope that either side would concede the debate over the 'open' and 'closed' shop. ${ }^{130}$ Affecting a similarly gloomy outlook, the Otago Daily Times claimed that 'both sides [were] too much dependent on Australia' for a reconciliation to occur. ${ }^{131}$ On 28 September, Employers' Associations justified press cynicism by refusing to attend the conference unless the Maritime Council allowed its members to work alongside non-union labour. ${ }^{132}$ The Press applauded the announcement, maintaining that the 'undoubted moral and legal right of employers to retain...free labour' underpinned successful enterprise. Furthermore, labour leaders were accused of advocating partisan interests ahead of those of "that far larger portion of the labor market which is not included in their attempted monopoly'. ${ }^{133}$ By contrast, the Lyttelton Times believed the employers risked making the same 'grave mistakes' as the Railway Commissioners and Whitcombe and Tombs. ${ }^{134}$

${ }^{130} E P, 16$ September 1890, p.2.

${ }^{131} O D T, 17$ September 1890, p.2.

${ }^{132} E P, 28$ September 1890, p.2.

${ }^{133}$ Press, 29 September 1890, p.4.

${ }^{134}$ LT, 29 September 1890, p.4. 
When the Labour Conference began on 1 October, both parties outlined entrenched positions that they refused to relinquish, nullifying the week's negotiations. Speaking first, George McLean defended the Union Company's motives and actions to the assembled delegates. He argued that the company paid investors 'reasonable' dividends ( 8 to 9 per cent annually), thus had not exploited its workforce in pursuit of exorbitant profits. He then turned on organised labour, describing their insistence on the closed shop as unreasonable and insubordinate. In response, John Millar asserted that the Maritime Council had instigated the strike on a matter of principle, rather than for economic reasons - the SSOA sought to limit its employees' freedom of association, a decision in which the Union Company was complicit. Yet, the strike reached New Zealand when the Council reluctantly responded to the company's decision to hire a non-union crew on the Wairarapa. Throughout, both Millar and John Lomas reiterated their opposition to union labour working alongside non-union labour. With neither side willing to compromise, the prospect of a resolution quickly faded. ${ }^{135}$ On 3 October, the Evening Post summarised the prevailing sentiments: 'The difference [between capital and labour] would appear so wide, so distinct, and so important as to preclude any other settlement than that of absolute surrender'. ${ }^{136}$ Neither side contemplated capitulation - the Maritime Council could hardly renounce the principles that had instigated the strike, while the Union Company attended primarily to set the terms of the unions' surrender. Thus, the conference ended fruitlessly on 6 October.

Although the press had predicted the failure of the conference, newspaper editors blamed the breakdown of negotiations on labour leaders. The Evening Post believed that new unionism created irreconcilable tensions between labour and capital.

\footnotetext{
${ }^{135}$ AJHR, 1891, First Session, H-1, pp.1-46; Merrett, 'A Reappraisal of the 1890 Maritime Strike', pp.132-38.

${ }^{136} E P, 3$ October $1890, \mathrm{p} .2$.
} 
Whereas 'the principles of old Unionism might be fairly conceded', the Maritime Council sought to 'become irresistible' and overwhelm its enemies. ${ }^{137}$ Later criticism followed the mould set by the Evening Post, as newspapers attacked the stubbornness of organised labour, yet praised the same trait in employers. The Otago Daily Times condemned the labour delegation for seeking 'terms that would impose the grossest humiliation on the victors'. Conversely, the paper lauded George McLean's negotiation on behalf of the abstaining employers. ${ }^{138}$ Ignoring McLean's veto of a proposed settlement, the New Zealand Herald commended the 'great patience and moderation' he displayed in his negotiations with the 'impudent' unionists. ${ }^{139}$ In a similar vein, the Press commended McLean's support for the 'open shop' but demonised his fellow delegates. Once again, the paper emphasised the pernicious influence of the union official, describing the strike as a vendetta conducted by ' $\mathrm{Mr}$ Millar and his co-leaders' against 'the producers of the colony'. ${ }^{140}$

The failure of negotiations in Wellington intensified criticism of John Millar in the press. By discrediting the Maritime Council executive, newspaper editors fostered the notion that socialist demagogues, rather than widespread working-class dissatisfaction with life in a 'workers' paradise', had instigated the strike. Millar's decision to continue the seamen's strike attracted particular criticism. The Evening Post attempted to create a rift between the Council executive and its members, calling upon the remaining strikers to ignore Millar's orders. Juxtaposed against his struggling cohorts, Millar was unfairly depicted as a fickle labour aristocrat, a 'mere bird of passage' who in defeat would 'shake the dust of New Zealand off his feet and

\footnotetext{
137 ibid.

${ }^{138}$ ODT, 8 October 1890 , p.2.

${ }^{139} \mathrm{NZH}, 7$ October $1890, \mathrm{p} .4$.

${ }^{140}$ Press, 8 October 1890, p.4.
} 
leave the country'. ${ }^{141}$ Overlooking the autonomy of the Maritime Council's members, the Press held Millar culpable for the attempt to 'kill the inter-colonial trade' and engineer a 'coal famine' in his 'war against the producers in the colony'. The paper argued that a 'handful of rash incapables' had subverted the labour movement, followed not by aggrieved workers, but by an unthinking labour force that had unwittingly injured its future prosperity. ${ }^{142}$

\section{The 'Reign of Terror' - After the Maritime Strike:}

Coinciding with the failure of negotiations, maritime traffic stabilised and coal production resumed. Unable to report on commodity shortages or violent 'outrages', the newspaper editors reassigned column inches to the election campaign. Although the strike continued until 10 November, its progress was barely noted in the press. Even John Millar's order for the remaining strikers to resume work was only reported by the Evening Post and Otago Daily Times. ${ }^{143}$ On 12 November, the Otago Daily Times celebrated the strike's demise. Considered the ultimate expression of new unionism, the Maritime Strike began because trade unions had abandoned conciliation and fashioned a 'distinctly aggressive character'. Having instilled 'an infectious mania' amongst its members, the Maritime Council executive embarked upon a premature strike, the failure of which was predicted by 'all outsiders'. By contrast, the paper praised the Union Steam Ship Company, concluding that 'their successful resistance of an attempted tyranny on the part of labour...rendered a service not only to employers, but to working men themselves' ${ }^{144}$

In the aftermath of the Maritime Strike, the labour movement collapsed. A number of Maritime Council affiliates, notably the MOMA, Cooks' and Stewards'

\footnotetext{
${ }^{141}$ EP, 10 October 1890 , p.2.

${ }^{142}$ Press, 10 October 1890, p. 2.

${ }^{143}$ EP, 11 November 1890, p.2; ODT, 11 November 1890, p.2.

${ }^{144}$ ODT, 12 November 1890, p.2.
} 
Union, and regional wharf labourers' associations, disappeared during or shortly after the strike, developments ignored by the press. At the wharves, employers formed labour bureaux that discriminated against former union members. ${ }^{145}$ In December, the Canterbury ASRS voted to separate from the Maritime Council, and required members' donations to liquidate debts incurred during the strike. ${ }^{146}$ On the West Coast, blacklisting became standard - to gain employment miners had to renounce their union membership. In February 1891, John Lomas travelled to Victoria to attend an AMALA meeting convened to reorganise Australasian mining unionism. $\mathrm{He}$ returned with $£ 200$, and when the hysteria subsided, assembled the remaining West Coast unionists. Only 49 of 300 miners attended, and instead of sacrificing the few remaining loyalists, the New Zealand AMALA disbanded. ${ }^{147}$ For Lomas, defeat proved less ignominious. He made tentative enquiries to Union Company officials regarding a subsidised passage to London in late 1890, but remained in New Zealand, later becoming a clerk and factory inspector at the Department of Labour. ${ }^{148}$

The Maritime Council fared little better, dissolving after its accounts were audited in February 1891. With the unions they represented either disintegrating or destroyed, the executive disbanded to begin the slow process of rebuilding trade unionism. Size was no guarantee of survival. The Maritime Council's largest affiliate, the FSU, suffered badly for its participation in the strike. The Auckland branch disbanded, not to reappear until 1897, and the Wellington and Dunedin branches were significantly diminished. William Belcher, FSU Secretary between 1894 and 1913, described the months following the strike in detail:

\footnotetext{
${ }^{145}$ Gardner, Prelude to Arbitration, p.119.

${ }^{146}$ Nolan, Kin, p.59.

${ }^{147}$ Len Richardson and Gerard Morris, The Denniston Miners' Union: A Centennial History, Westport: Denniston Miners' Union Centennial Committee, 1984, p.20.

${ }^{148}$ Len Richardson, 'Lomas, John 1848-1933', Dictionary of New Zealand Biography; available from http://www.dnzb.govt.nz/DNZB/alt essayBody.asp?essayID=2L17; accessed 22 July 2010.
} 
Then began what may be termed the "reign of terror". Every conceivable device was brought into action to try and retard the new growth of unionism. The employers contended that it was their duty to stand by the "loyalists" and the strikers got little or no chance of work...Added to this was the large element of non-unionists who were as ignorant of the principles of unionism as they were of the beauties of [the] Pleiades. These men had to be educated. To get near them on board of ship was well nigh impossible, and the Union official or delegate was for many years absolutely prohibited from boarding a vessel. The men were also very reluctant about approaching the Union officers for fear of being victimised. ${ }^{149}$

Trade unions were not the only victims of the strike's failure. Melanie Nolan argues that 1890 marked both 'the beginning and end of large scale Trans-Tasman industrial action'. ${ }^{150}$ Some formal Australasian labour associations survived, but the unity displayed by the colonial maritime labour federations in 1890 would never recur. ${ }^{151}$

The economic impact of the strike is difficult to quantify, but available trade figures suggest that it did not jeopardise the colony's economic recovery. Although the total number of vessels arriving in New Zealand ports fell from 781 in 1889 , to 744 in 1890 , total trade increased from $£ 15,350,811$ to $£ 15,689,286$, or by slightly over one shilling per capita. Despite production stoppages on the West Coast, the amount of coal extracted in 1890 was an increase on the previous year. 1889 saw the first drop in production since figures were first collected in 1878, and in 1890 total production rose from 586,445 tons to 637,397 tons. Seemingly, the only concession to the strike was a minor decrease in coal exports, from 86,405 tons in 1889 , to

\footnotetext{
${ }^{149}$ W. Belcher to J.D. Salmond, undated, Roth Papers, MS-Papers 94-106-29/02, ATL.

${ }^{150}$ Melanie Nolan, 'Maritime Strike, Australasia 1890', in Neil Schlager (ed.), St. James Encyclopedia of Labor History: Major Events in Labor History and their Impact, Volume One, Detroit: St. James Press, 2003, p.590.

${ }^{151}$ Melanie Nolan describes these enduring connections as 'Australasian assignations' and outlined their history in 'A Australasian Assignations?' The Impact of the '1890' Generation and the Maritime Strike on later Trans-Tasman Unionism', in Frances Laneyrie and Raymond Markey (eds.), Globalisations and Labour in the Pacific: Re-evaluating the 1890 Maritime Strike Symposium Proceedings, Auckland: New Zealand Work and Labour Market Institute, 2010, pp.53-65.
} 
76,388 tons the following year. ${ }^{152}$ These figures belie the cause and effect arguments of contemporary conservatives who sought to transfer the liability for falling profits from capital to labour. ${ }^{153}$

The strike also influenced the colony's decision to remain outside the Australian federation movement. Undoubtedly, the declining importance of Australasian trade (in 1870, Australia received 46 per cent of the total value of New Zealand exports, a figure that fell to 16 per cent in 1890) was the most significant reason behind New Zealand's refusal to join the Australian federation. ${ }^{154}$ Yet, for many, the Maritime Strike reinforced suspicions that federation would disadvantage the colony. The notion that the strike had spread to New Zealand at the behest of Australian labour organisers was widely held by contemporaries. Echoing such sentiments, on 13 September, the Otago Daily Times remarked that 'this rude lesson' demonstrated that an Australasian federation would be 'terribly oppressive to New Zealand'. ${ }^{155}$ Although one factor amongst many, the strike and its Australian associations disturbed the political elite, and deepened the ambivalence they felt towards joining an Australian federation.

For the most part, the press was complicit in the downfall of the Maritime Council. However, their antagonism to the emergence of a robust and assertive labour movement has yet to be adequately explained. Documenting similar anti-labour sentiments in the Australian press, Stuart Svensen argues that the phenomenon was primarily economic: 'As shipping companies were a major source of advertising revenue, the SSOA enjoyed a near-total monopoly of support from the metropolitan

\footnotetext{
${ }^{152}$ Author's calculations from Statistics of the Colony of New Zealand 1888-1891, Wellington: George Didsbury, Government Printer, 1888-1892.

${ }_{153}$ Bennett, 'The 1890 Maritime Strike and the Triangular Relationship', pp.31-32.

${ }^{154}$ Miles Fairburn, 'New Zealand and Australian Federation, 1883-1901: Another View', NZJH, Vol. 4 , no. 2,1970, p. 152 .

${ }^{155}$ ODT, 13 September 1890, p.2.
} 
daily papers'. ${ }^{156}$ When applied to the New Zealand press, the theory holds little weight. Paid shipping news was a fixture on the front pages of all newspapers in port towns, regardless of their political persuasion. Although the Lyttelton Times and Grey River Argus published strident criticism of the Union Company, both maintained commercial relationships with the company. Furthermore, the Lyttelton Times' circulation figures increased during the strike. The paper's circulation figures lifted from 7,685 readers in July, to 7,816 in August - potentially offsetting lost advertising revenues and suggesting that readers shared the paper's sympathy for the strikers. ${ }^{157}$ It is interesting to note however, that the Maritime Council spent less than $£ 3$ on advertising during the strike, paling in comparison to the shipping companies' daily expenditure on column space. ${ }^{158}$

As a general rule, Laurel Hepburn's observation that newspapers reported news in a fashion consistent with the class and politics of their controllers holds weight - if only because these controllers almost always belonged to the elite. Nineteenth century newspaper proprietors and editors had the utmost faith that their enterprises were socially powerful and persuasive agencies. ${ }^{159}$ Thus, it was hardly surprising that the Press, a newspaper with a conservative tradition and newly acquired by George Stead, a leading figure in the capitalist strike-breaking machine, established itself as the strike's leading critic. By the same token, the labour advocacy of the Lyttelton Times can be attributed to the political convictions of its owner-editor William Pember Reeves. Yet, Hepburn's theory fails to explain the stance taken by papers like the Evening Post or Otago Daily Times. As Reeves noted, the Daily Times had led public opinion on the exploitation of female workers, and would conduct future

\footnotetext{
${ }^{156}$ Svensen, The Sinews of War, p.122.

${ }^{157}$ LT, 4 September 1890 , p.4.

158 'Balance-Sheet of the Strike Defence Fund', 1890-1891, Roth Papers, MS-Papers 94-106-29/04, ATL.

159 Jones, Powers of the Press, p.180.
} 
labour advocacy campaigns under George Fenwick. Thus, it cannot be considered an antediluvian enemy of the working-class. ${ }^{160}$ Similarly, the Evening Post had advocated workers' rights earlier in the year, and despite its criticism of the Maritime Council, remained an opponent of the Atkinson Government. Economic and political locations aside, all newspapers aside from the Lyttelton Times and Grey River Argus deliberately employed consensus rhetoric, masking the reasons behind the largest strike in the colony's history.

The dominant framing of the strike, as a minor disturbance to colonial consensus, bears similarities to the fixation on egalitarianism that has prevailed in New Zealand labour historiography since William Pember Reeves' 1902 State Experiments in New Zealand and Australia. ${ }^{161}$ New Zealand's colonists regarded the tight-knit, egalitarian, and stable agrarian society they had forged in Pacific isolation with pride - sentiments evident during the 'sweating' scandal. ${ }^{162}$ Just as early official publications rarely featured material that detracted from this Arcadian narrative, newspaper editors eagerly juxtaposed the relative comfort of workers' wages and conditions with the surly rhetoric of their leaders. ${ }^{163}$ By contrast, the press never respected the Maritime Council's principled opposition to the possibility of an enforced 'open shop'. Elite attitudes toward organised labour were encapsulated by the November 1890 report of the Royal Commission on Grey Valley Mines, which condemned trade unions as vehicles for migrant agitators to entrench their social position through the exercise of 'despotic power'. ${ }^{164}$ By relegating the extraordinary progress of new unionism to a brand of charlatanism practiced by charismatic leaders

\footnotetext{
${ }^{160}$ George Griffiths, 'Fenwick, George 1847 - 1929', Dictionary of New Zealand Biography; available from http://www.dnzb.govt.nz/DNZB/alt_essayBody.asp?essayID=2F4; accessed 8 July 2010.

${ }^{161}$ Reeves, State Experiments in New Zealand and Australia.

${ }^{162}$ Nolan, 'The Reality and Myth of New Zealand Egalitarianism', pp.113-34.

${ }^{163}$ The utopian element in early New Zealand national identity has been examined by Dominic Alessio, 'Promoting Paradise: Utopianism and National Identity in New Zealand, 1870-1930', NZJH, Vol. 42, no. 1, April 2008, pp.22-41.

${ }^{164}$ AJHR, C-3, 1891, p.16; Richardson, Coal, Class and Community, p.52.
} 
upon misguided workers, newspaper editors carefully maintained an image of consensus. Yet, the production and reproduction of the egalitarian myth cannot merely be considered a cynical ploy of the elite. Myopic as it may seem, the majority of the press genuinely believed that the public would confirm their convictions at the forthcoming General Election by repudiating the opposition, and returning the Atkinson Government with a renewed mandate. 


\section{Chapter Four: From the Pit into Parliament? Organised Labour and the General Election of 1890.}

After the turmoil of the Maritime Strike, the 1890 General Election presented voters with the opportunity to support social reform or repudiate the demands of political and industrial reformers. For the first time, the election was contested along rough party lines, with the Opposition Liberals seeking to overthrow Sir Harry Atkinson's ragged government of hard-line conservatives, free-traders, and moderates. Despite industrial defeat, trade unions organised politically, officially supporting the Liberals - though the terms of their alliance varied regionally. Eager to thwart the rise of the 'Reds', conservative newspapers and candidates alike ridiculed labour's political ambitions, reminding voters that Opposition candidates were not 'true' New Zealanders, but dangerous radicals who had enabled the disastrous strike. ${ }^{1}$ Liberal newspapers and candidates internalised this position and assiduously avoided the landmark dispute in their speeches and manifestos. Yet, by focussing on the strike, instead of the unprecedented mobilisation of thousands of voters, the democratising impact of electoral reform, and widespread prejudices against wealthy runholders and landlords, conservatives underestimated the challenge they faced on polling day. Conversely, the liberal press sought to capitalise on trade unions' gains by co-opting workers into the Opposition fold, marginalising radical voices in the process. Desperate to prevent vote-splitting, the Liberal 'machine' warned workers that an alliance with middle-class radicals and moderate farmers, primarily a vote for land and taxation reform, was the only way to prevent a ruinous conservative victory.

\footnotetext{
${ }^{1}$ John Hall to John Ormond, 15 December 1890, Hall Letter Book, p.236, in McIvor, The Rainmaker, p.179.
} 


\section{A History of the Franchise in New Zealand:}

After the assumption of British authority over New Zealand under the Treaty of Waitangi in 1840, a Crown appointed Governor ruled the colony. Colonial administration was undertaken by an appointed Executive Council, while the Legislative Council met sporadically to pass legislation. Early immigrants, influenced by British liberalism and radicalism, chafed under the autocratic rule of the Governor, and formed Constitutional Associations demanding self-government. Although most were influenced by the Westminster system they had left behind, 'the most respectable [men] of every class', from artisan radicals to educated elites contested the nature of any future democracy. ${ }^{2}$ Most favoured open voting and a limited franchise, yet some, inspired by Chartism, desired further reform - championing universal male suffrage, the secret ballot, and annual parliaments. ${ }^{3}$

After a decade of debate, the British Parliament passed the New Zealand Constitution Act on 30 June 1852. The Act established a General Assembly, which comprised a Governor, an appointed Legislative Council, and a 37 member elected House of Representatives. 'Modest' qualifications limited the franchise to males aged over 21, provided they owned or leased property of a certain value. Those qualified could vote in every district they held property. Aside from Māori, who were effectively disenfranchised because of communal land tenure, contemporaries considered New Zealand's franchise generous, an assessment historians have generally accepted. ${ }^{4}$ In 1864 , the Canterbury journalist and politician James

\footnotetext{
${ }^{2}$ Martin, The House, p.10; John Miller, Early Victorian New Zealand: A Study of Racial Tension and Social Attitudes 1839-1852, Wellington: Oxford University Press, 1958, p.151.

3 Neill Atkinson, Adventures in Democracy: A History of the Vote in New Zealand, Dunedin: University of Otago Press, 2003, p.19.

4 Atkinson, Adventures in Democracy, pp.19-27; Leslie Lipson, The Politics of Equality: New Zealand's Adventures in Democracy, Chicago: The University of Chicago Press, 1948, p.19; Martin, The House, p.11.
} 
FitzGerald boasted, 'there is hardly a man who cannot get a vote in New Zealand'.5 By contemporary standards, the 1852 franchise was liberal, yet a significant proportion of colonists could not vote. According to the 1858 Wellington provincial census, 882 of 3,379 Pākehā males aged over 21 were unqualified to vote. The restriction prevented 'opportunistic sojourners' - recent immigrants and itinerant labourers - from disrupting colonial politics. ${ }^{6}$

Until the late 1870s, the franchise enshrined under the Constitution Act 1852 expanded gradually. The Representation Act 1860 extended the vote to adult males who held a miners' right (at an annual cost of £1), while the Māori Representation Act 1867 allowed all adult Māori males to vote in four special electorates. ${ }^{7}$ Yet, universal male suffrage had been introduced in South Australia, Victoria, New South Wales, and Queensland by 1860, and in 1867, the Second Reform Act enfranchised all male householders in Britain. By contrast, the New Zealand political system remained 'ludicrously complicated' - different voting qualifications applied to freeholders, leaseholders, rural and urban householders, lodgers, ratepayers, miners, and Māori. ${ }^{8}$ Voter participation was low by later New Zealand standards. Between 1855 and 1875 , voter turnout fluctuated between 46 and 61 per cent. ${ }^{9}$ Political instability precluded electoral reform. Between 1876 and 1879, five ministries held office, and legislative measures to expand the franchise were consistently defeated.

In December 1879, the Hall Government passed the Qualification of Electors Bill, granting the vote to all adult males after 12 months' residence in the colony. Plural voting and the freehold qualification were retained, but proposed amendments to

\footnotetext{
5 J.E. FitzGerald, The Representation of New Zealand, Christchurch: Press Office, 1864, p.9.

${ }^{6}$ Wellington Provincial Census, 31 March 1858, Government Gazette (Province of Wellington), 8 November 1858, in Atkinson, Adventures in Democracy, pp.35-36.

${ }^{7}$ B.S. Gustafson, Constitutional Changes Since 1870, Auckland: Heinemann Educational Books, 1969, p.35.

${ }^{8}$ Atkinson, Adventures in Democracy, p.63.

9 John E. Martin, 'Political Participation and Electoral Change in Nineteenth-Century New Zealand', Political Science, Vol. 57, no. 1, June 2005, p.44.
} 
enfranchise women who met the property qualifications were omitted from the approved legislation. The new measures significantly enlarged the electorate and heralded the beginning of demotic, colony-wide politics. Before the Bill's passage, there were 82,271 registered Pākehā voters: 71 per cent of the Pākehā male population. By 1881, that figure had risen to 120,972 : 91 per cent of the Pākehā male population. ${ }^{10}$ Plural voting remained until 1889, when George Grey introduced a 'one-man, one-vote' provision to the Representation Act Amendment Bill. ${ }^{11}$ Aside from Māori property owners, in the forthcoming election all male New Zealanders would be restricted to voting in a single electoral district, virtually completing the democratisation of the male franchise.

\section{The Political Labour Movement to 1890:}

New Zealand historians have traditionally amalgamated the collapse of the Maritime Strike in November and the December election campaign into a narrative documenting the rapid transition of the labour movement from an industrial to a political force. ${ }^{12}$ The argument overemphasises the uniqueness of 1890 at the expense of over ten years of working-class political action. Capitalising on the spirit of intertrade cooperation fostered by a series of anti-Chinese immigration rallies in early 1879, union representatives established the Auckland Working Men's Political Association (WMPA) in August. The Association, founded to 'secure the better representation of the working classes in Parliament', began life as a vehicle to disseminate an anti-Chinese, protectionist political agenda - the descendant of the

\footnotetext{
${ }^{10}$ Atkinson, Adventures in Democracy, pp.70-71.

11 Edmund Bohan, To Be A Hero: Sir George Grey, 1812-1898, Auckland: Harper Collins, 1998, p.313.

12 John E. Martin, Honouring the Contract, Wellington: Victoria University Press, 2010, pp.99-109, revises this interpretation.
} 
anti-immigration Working Men's Protection Societies founded in Auckland and Christchurch in $1871 .^{13}$

Two years later, Christchurch unionists established a sister organisation, pledging to 'use every legitimate effort to obtain a representation of Labour in the General Assembly'. ${ }^{14}$ The Christchurch WMPA articulated a nuanced manifesto, combining liberal land and taxation policy with radical demands for triennial parliaments, an elected upper house, and universal manhood suffrage. ${ }^{15}$ At the landmark January 1885 Trades and Labour Councils' Conference in Dunedin, delegates from across New Zealand outlined the political aspirations of the labour movement. The conference passed a motion calling upon regional unions to select 'an artisan or labourer' to stand at the next election, a commitment reaffirmed at the 1886 conference. ${ }^{16}$ The task was daunting. Of the 40 Wellington MHRs elected by 1896 , almost 90 per cent were 'high white collar' (merchants, professionals, pastoralists) a situation replicated across the colony. ${ }^{17}$

Forestalling the progress made since 1879, economic depression attenuated organised labour's immediate political ambitions. By the end of 1886, all of the TLCs and WMPAs had collapsed as the labour movement struggled through economic doldrums. Undeterred by the immediate organisational vacuum, trade unions became an integral part of the Liberal coalition in 1890. In 1887, William Pember Reeves

\footnotetext{
${ }^{13}$ Martin, Honouring the Contract, p.100; Salmond, New Zealand Labour's Pioneering Days, p.125. Racism and labour activism had a long association. In 1872, James McPherson, founder of the Canterbury Working Men's Mutual Protection Society, published a pamphlet entitled Reasons Why the Working Men of New Zealand Should Become Internationalists, Together With An Article Entitled Anti-Chinese Immigration. Erik Olssen argues that 'hatred of the Chinese may have been the key catalyst of class' as they not only represented a feared racial other, but were considered 'cheap, docile, deferential workers' favoured by colonial merchants. Olssen, A History of Otago, p.105. For discussion of racism and the working-class in Australia, see Ann Curthoys and Andrew Markus (eds.), Who Are Our Enemies?: Racism and the Australian Working Class, Neutral Bay: Hale and Iremonger, 1978.

${ }^{14}$ Thorn, The Formation and Development of Trades Unionism in Canterbury, p. 12.

${ }^{15}$ McAloon, 'Radical Christchurch', in Cookson and Dunstall (eds.), Southern Capital, pp.165-66.

16 Thorn, The Formation and Development of Trades Unionism in Canterbury, p. 14.

${ }^{17}$ James Belich, Making Peoples: A History of the New Zealanders from Polynesian Settlement to the End of the Nineteenth Century, Auckland: Penguin Books, 1996, p.407.
} 
formed the Canterbury Electors' Association, which released a manifesto combining 'provincialism with a "liberal" working class policy'. ${ }^{18}$ The Association had a broad base, yet retained a radical flavour, denouncing the wealthy and courting workingclass voters. Reeves organised a popular ticket, winning seven seats - the core of which formed his 'United Liberal' bloc in the 1890 election. ${ }^{19}$ In Dunedin, unionists founded the Caversham Labour Representation Committee in 1887 to unseat the longstanding local MHR, Sir William Barron, after he voted against eight-hour day legislation. Barron retained his seat, but the Committee's candidate, Caversham Borough Council President Richard Rutherford, polled strongly, securing almost 40 per cent of the vote. ${ }^{20}$

The rise of organised labour in New Zealand coincided with the early development of party politics. As with new unionism, the desire for political reform emerged during the 'Long Depression', as New Zealanders grew disillusioned with their prospects of improvement. Vast rural estates, amassed by pioneering runholders, stifled the opportunities of a growing population eager to exploit the economic possibilities created by the advent of refrigerated transportation. ${ }^{21}$ Yet, as Tom Brooking argues, the 'land question' cannot be reduced to economics - concerns about debt repayment, productivity, wealth distribution, concentration of political power, and sentimental attachments all informed contemporary debates. ${ }^{22}$ To remain a settler society that rewarded industry with individual advancement, the colony

\footnotetext{
${ }^{18}$ Clive Whitehead, 'The 1887 General Election in Canterbury', MA thesis, University of Canterbury, 1961, p.28.

19 Keith Sinclair, 'Reeves, William Pember 1857-1932', Dictionary of New Zealand Biography; available from http://www.dnzb.govt.nz/dnzb/alt essayBody.asp?essayID=2R11; accessed 29 July 2010.

${ }^{20}$ Olssen, Building the New World, p.170; Otago Witness, 30 September 1887, p.16.

${ }^{21}$ In 1890, 422 individuals and companies (less than one per cent of property owners) owned 64 per cent of the 12.5 million acres of freehold land in New Zealand. Tom Brooking, Lands for the People? The Highland Clearances and the Colonisation of New Zealand: a Biography of John McKenzie, Dunedin: Otago University Press, 1996, p.75; Sinclair, A History of New Zealand, pp.166-67.

${ }^{22}$ Brooking, Lands for the People?, p.80.
} 
required urgent political reform. Although global economic problems brought hard times to the colony, the government's capacity to address colony-wide problems increased during the $1880 \mathrm{~s}$. The end of the provincial system in 1876 saw central government assume responsibility for land legislation, extend its powers of taxation, and eventually establish departments responsible for colony-wide infrastructure, such as the Post Office and railways. As John Martin notes, during the centralisation of power, successive governments realised that state intervention was required to redress growing economic disparities and social unrest. ${ }^{23}$

Concurrent with the emergence of new political demands, the composition of the House of Representatives underwent a renewal. By the 1880 s, politics was regarded as a long-term commitment - a career of hard work and service, rather than an esoteric, gentlemanly pursuit. A new breed of career politicians with backgrounds in journalism, commerce, and the professions succeeded the 'patrician runholder bloc' that had previously dominated the House. As the franchise expanded, accountability increased - re-election required the formation of enduring connections between the debating chamber and the voting public. Political speakers began touring the colony, while in the main centres election campaigns were organised on bloc tickets. The factional system of government, within which members vied for power in isolation from the electorate, was superseded by a form of political organisation that better represented voters' concerns. $^{24}$

At the forefront of these new trends in political organisation was the nascent Liberal coalition, which emerged as a coherent Opposition to the Atkinson Government after the 1887 election. It is important to note that the term 'liberal' was used indiscriminately in New Zealand politics; 'everybody wanted to be known as a

\footnotetext{
${ }^{23}$ Martin, The House, p.103.

${ }^{24}$ ibid., pp.103-05.
} 
"liberal", regardless of practice. ${ }^{25}$ However, the first parliamentary group to consistently refer to themselves as 'Liberals' gathered under the leadership of Sir George Grey in the late 1870s. Grey established Liberal Associations across the colony, the antecedents of an unrealised central organisation. ${ }^{26}$ David Hamer questions Grey's influence on the Liberal party of the 1890s, arguing that he created a rhetorical division between putative liberals and conservatives to serve his own agenda. The fall of the Stout-Vogel Government (1884-1887) crystallised divisions within the House, as the Stout-Vogel group entered opposition 'more or less as a body', rather than disintegrating into factions. ${ }^{27}$ Yet, emblematic of the politics of the era, John Ballance - a prominent minister in that Cabinet - seldom mentioned a Liberal party during the election campaign. Instead, he sought to emphasise the liberal quality of his own achievements, while distancing himself from the inconsistent record of the government. ${ }^{28}$

When the Tenth Parliament convened in October 1887, the loan-money that fuelled provincial competition for public works projects had evaporated, foreshadowing a bleak economic outlook. ${ }^{29}$ Elected during the height of the depression, Harry Atkinson cobbled together a 'Scarecrow Ministry' of free-traders, 'skinflints', and moderate conservatives, united by a common antipathy to Vogel and a desire for retrenchment. ${ }^{30}$ From its inception, Atkinson's premiership faced criticism from all sides. Despite sharing his aversion to tax increases, the 'skinflints' lambasted the continued reliance on foreign capital in the 1887 and 1888 budgets. Meanwhile, the Opposition disparaged Atkinson's aversion to industrial protection

\footnotetext{
${ }^{25}$ Hamer, The New Zealand Liberals, p.18.

26 Keith Sinclair, The Liberal Government, 1891-1912: First Steps Towards a Welfare State, Auckland: Heinemann Educational Books, 1967, p.3.

${ }^{27}$ Hamer, The New Zealand Liberals, p. 24.

${ }^{28}$ McIvor, The Rainmaker, p.152.

${ }^{29}$ Sinclair, A History of New Zealand, pp.168-69.

${ }^{30}$ McAloon, No Idle Rich, p.107; T.G. Wilson, The Rise of the New Zealand Liberal Party, 1880-90, Auckland: Auckland University College, 1956, p.28.
} 
and commitment to retrenchment rather than financial reform. In May 1888, Atkinson's decision to increase customs duties further destabilised the government. The provision, defended as an unavoidable revenue gathering measure, passed through the House, but enraged free-traders and fragmented the government. ${ }^{31}$ While the economy had lifted by 1889 and the government reported a small surplus, Atkinson's hold over the premiership remained tenuous, especially as poor health curtailed his appearances in the House. Conservatives never regained their trust in Atkinson, and feared his unrealised, reformist ambitions, while the equally fragile Opposition condemned the government's failure to alleviate the depression, address growing urban inequality, and Atkinson's obstinate neutrality in the labour disputes that wracked the colony. ${ }^{32}$

As the 1890 election loomed, New Zealand seemed 'stuck in political as well as economic despair'. ${ }^{33}$ With large-scale borrowing unfeasible, twenty years of pork barrel politics ended and allowed the development of new 'national' politics. Liberalism, with its focus on reform that transcended provincial limitations, was the dominant response to the new political environment. ${ }^{34}$ Yet, those outside the government did not resemble a cohesive Opposition until the unanimous election of John Ballance as leader on 20 June 1889. Significantly, a broad caucus, rather than a provincial bloc selected Ballance. ${ }^{35}$ David Hamer has suggested that $1880 \mathrm{~s}$ parliamentarians were overwhelmingly concerned with retrenchment and stable

\footnotetext{
${ }^{31}$ Paul Goldsmith, We Won, You Lost. Eat That! A Political History of Tax in New Zealand Since 1840, Auckland: David Ling, 2008, p.79.

${ }^{32}$ Sinclair, 'The Significance of 'the Scarecrow Ministry', in Chapman and Sinclair (eds.), Studies of a Small Democracy, pp.114-26.

${ }^{33}$ Judith Bassett, Sir Harry Atkinson, 1831-1892, Auckland: Auckland University Press, 1975, pp.15657.

${ }^{34}$ Sinclair, 'The Significance of 'the Scarecrow Ministry', 1887-1891', in Chapman and Sinclair (eds.), Studies of a Small Democracy, p.109.

${ }^{35}$ McIvor, The Rainmaker, p.158.
} 
government. $^{36}$ Despite sharing these common interests, Opposition MHRs differentiated themselves from Atkinson's supporters on several fundamental, if vaguely defined issues: land and taxation reform, the nature of future retrenchment, and a commitment to expanding the political role of organised labour. ${ }^{37}$

Nevertheless, organised labour fitted uneasily into John Ballance's plans to forge a robust Opposition 'party' that could defeat the Atkinson Government in the 1890 general election. John Angus, in his analysis of late nineteenth century Otago politics, discerned two factions within the Liberal party: former supporters of the Stout-Vogel Government, and candidates representing organised labour. Angus argues that established Liberals such as Ballance and Sir Robert Stout adopted more radical positions to accommodate the labour faction and prevent them from splitting the vote by moving even further to the left. Yet, countervailing pressure from the 'moderate farmer element' tempered the radical faction within the emerging Liberal coalition. ${ }^{38}$ Although sympathetic to workers' concerns, Ballance's liberalism was 'broad based rather than sectional'. ${ }^{39}$ He courted the broadest possible segment of the electorate, and believed the election would be fought over the land question, and in particular, the government's failure to promote closer land settlement. With land nationalisation atop his agenda, Ballance considered industrial tensions a subsidiary issue - to be properly addressed when land tenure reforms alleviated the chronic depression. ${ }^{40}$

During the previous decade, trade unions had complemented industrial action with political activism, a trend amplified, rather than originated, by the failure of the Maritime Strike. The difference between the 1890 election and previous elections was the decision by organised labour to seek direct parliamentary representation, rather

\footnotetext{
${ }^{36}$ Hamer, The New Zealand Liberals, pp.26-29.

${ }^{37}$ McAloon, No Idle Rich, p.106.

${ }^{38}$ Angus, 'City and Country', pp.7, 508-09.

39 Timothy J. McIvor, 'On Ballance: A Biography of John Ballance, Journalist and Politician, 18391893', PhD Thesis, Victoria University of Wellington, 1984, p.485.

${ }^{40}$ McIvor, The Rainmaker, pp.165-71.
} 
than relying solely on the uncertain support of middle-class radicals. Respected politicians such as Sir Robert Stout and Sir George Grey advocated working-class political representation, and sought to convince the public of the trade unionists' responsibility and respectability, while encouraging the unionists to co-operate with 'public opinion' (by which they meant the middle classes). ${ }^{41}$ The June 1890 session revealed the danger of depending on the established Opposition, when the Atkinson Government responded to the Sweating Commission report by tabling a series of Labour Bills. The proposed legislation anticipated, and in some areas surpassed, the Liberals' future labour programme, but received little bi-partisan support. ${ }^{42}$ Early Closing, Eight Hours, and Bankruptcy Bills failed to pass the first reading in the House, while the Factories and Shops Bill was delayed in Committee until it lapsed when Parliament adjourned in September. The Employers' Liability Bill and the Shipping and Seamen's Act Amendment Bill passed through the House, yet the Legislative Council vetoed both measures. ${ }^{43}$ Atkinson's belated attempts at industrial reform were hampered by a weak and divided government, a reactionary Legislative Council, and an Opposition content to watch the government 'sink deeper into the political morass' regardless of the consequences for labour. ${ }^{44}$

As with the parliamentary Opposition, no single political platform unified organised labour during the election campaign. Instead, the idea of a 'Labour party' as a vehicle for reform emerged organically in the urban centres. ${ }^{45}$ In October 1889 , the Maritime Council did not explicitly promote working-class representation in parliament, instead choosing to 'use its influence in support of or in opposition to any

\footnotetext{
${ }^{41}$ D.A. Hamer, 'Sir Robert Stout and the Labour Question, 1870-1893', in Chapman and Sinclair (eds.), Studies of a Small Democracy, pp.95-96.

${ }^{42}$ Martin, '1890: A Turning Point', in Walsh (ed.), Pioneering New Zealand Labour History, pp.41-49.

${ }^{43}$ Basset, Sir Harry Atkinson, p.157.

${ }^{44}$ Angus, 'City and Country', p.494; Martin, '1890: A Turning Point', in Walsh (ed.), Pioneering New Zealand Labour History, p.48.

${ }^{45}$ Olssen, Building the New World, pp.180-81.
} 
bill or bills affecting maritime labour' ${ }^{46}$ The Council exercised its lobbying power during its Wellington conference, when the executive met with Atkinson to discuss his ill-fated labour legislation. Yet, the conference also foreshadowed unionists' desire for political representation. Several newspapers reported that conference delegates considered 'the question of a labour platform at the next general election...at great length', but failed to reach any conclusions as they struggled to negotiate settlements in the Shag Point and Petone Woollen Mill disputes. ${ }^{47}$ The urgency of industrial action over the following months hindered the development of a comprehensive political platform, but amid the turmoil of the Maritime Strike, a labour manifesto emerged. ${ }^{48}$ Importantly, mass organisations, rather than small cadres of middle-class radicals and labour activists (as had been the case in the 1880s), promulgated these new political desires. ${ }^{49}$

For over a year before the election, union leaders urged members to join the electoral roll. Yet, labour's political activities remained confined to voter registration until late August $1890 .{ }^{50}$ On 23 August a gathering of Christchurch trade unionists established the People's Political Association (PPA). Similar to the defunct Canterbury Electors' Association, the PPA acted as a de facto Christchurch Liberal election committee, and articulated a platform of land and labour reform similar to the 'Liberal manifesto' published by the Lyttelton Times on 19 September. Both William Pember Reeves and the PPA advocated for a progressive land and income

\footnotetext{
46 'Proposed Basis of the Maritime Council', 1889, Roth Papers, MS-Papers 94-106-29/04, ATL.

${ }^{47}$ Press, 18 May 1890, p.5; North Otago Times, 20 May 1890, p.2.

${ }^{48}$ See Appendix Two for a comparison of the labour election manifestos released between August and November 1890.

49 Angus, 'City and Country', p.501.

50 Christopher Campbell, 'Parties and Special Interests in New Zealand 1890-1893', MA thesis, Victoria University of Wellington, 1978, p.30.
} 
tax, ensuring the availability of smallholdings for workers and farmers, continued public works spending, and the implementation of a new suite of labour legislation. ${ }^{51}$

However, tensions existed between the established Liberals and the emerging labour faction in the Christchurch electorate. William Pember Reeves feared that overt politicisation of the trade union movement would 'driv[e] a wedge' through the Liberal vote, and warned labour against over-ambition: 'directly they go beyond this point [industrial activism] and form themselves into a political association, they will begin to lose ground with the moderate portion of the public'.52 William Tanner, a bootmaker and the labour candidate for the suburban Heathcote seat, objected to the paternalism of the middle-class radicals, arguing that 'working men...would not be satisfied with "working men's friends" but would insist on the genuine article'. ${ }^{33}$ Yet, such tensions did not prevent the labour faction and the established Opposition from uniting behind a joint ticket: incumbents Reeves, R.M. Taylor, and W.B. Perceval stood in the city electorate; Tanner in Heathcote; W. Hoban (ASRS President) in Kaiapoi; and John Joyce (journalist and incumbent MHR) in the Akaroa electorate. ${ }^{54}$ No candidate was selected to contest the Avon seat - perhaps to increase the chance that Edwin Blake, the incumbent, could defend the seat against George Stead.

Shortly after the formation of the Christchurch PPA, the Otago TLC held a meeting in conjunction with the Maritime Council, and formed the Labour Parliamentary Committee (LPC). Although the older craft unions protested the politicisation of the labour movement, most Dunedin unions sent representatives. Sir Robert Stout refused to stand as a labour candidate, and the LPC selected David Pinkerton (Otago TLC President), William Earnshaw (a brass-founder), and William

\footnotetext{
${ }^{51}$ McAloon, 'Radical Christchurch', in Cookson and Dunstall (eds.), Southern Capital, pp.169-70.

${ }^{52} L T, 9$ July 1890, p.4.

${ }^{53} L T, 8$ October 1890, p.5.

${ }^{54}$ McAloon, 'Radical Christchurch', in Cookson and Dunstall (eds.), Southern Capital, p.170.
} 
Dawson (a wealthy brewer) to stand in the city electorate. The trio, funded by the TLC, campaigned on a platform of industrial protection, labour legislation, public works spending, and the introduction of a progressive land and income tax. ${ }^{55}$ Notably absent from the agenda was fragmenting the large estates, the cornerstone of Ballance's campaign. Erik Olssen examined the complicated relationship urban workers had with the land question in his discussion of class in late nineteenth century New Zealand. Although some aspired to become farmers, 'it is far from clear that the enthusiasm for breaking up the great estates invariably meant a desire for land ${ }^{56}$ In the Otago Workman, Samuel Lister gave three reasons why urban workers benefited from land reform. Breaking the runholders' estates would cement the Liberal alliance between unionists and small farmers, diminish the power of the wealthy monopolists who had conspired to defeat the Maritime Strike, and settle the itinerant rural labourers who had been mobilised as strike-breakers. ${ }^{57}$ Contrary to the Liberals' populist ambitions, indignation with the crushing defeat of the Maritime Strike fuelled labour politics in Dunedin. ${ }^{58}$

As in Christchurch and Dunedin, the Wellington TLC provided the organisational impetus for the articulation of a workers' political platform. After a meeting on 3 October, the Council printed pamphlets outlining a 'wage-earners' manifesto'. ${ }^{59}$ The manifesto called for candidates seeking wage-earners' votes to support the breaking of large estates via a programme of legislation and taxation, cessation of Crown land sales, preservation of the current education system, industrial protectionism, foreign labour restrictions, and the transition to an elected Legislative Council. ${ }^{60}$ The TLC

\footnotetext{
55 The Otago TLC gave Pinkerton $£ 95$, Earnshaw $£ 50$, and $£ 65$ to John Millar who was standing for the Port Chalmers seat. Angus, 'City and Country', pp.501, 509.

${ }^{56}$ Erik Olssen, 'The 'Working Class' in New Zealand', NZJH, Vol. 8, no. 1, May 1974, p.51.

${ }^{57}$ Otago Workman, 4 October 1890, p.4.

${ }^{58}$ Olssen, Building the New World, p.181.

${ }^{59} E P, 4$ October 1890, p.2; EP, 6 October 1890, p.2.

${ }^{60} E P, 6$ October 1890, p.2.
} 
also selected a list of candidates to contest the city's electorates, all of whom were jointly endorsed by the Liberal party. William McLean (Secretary of the Empire Loan Company), T.K. MacDonald (WWC Chairman), and F.H. Fraser (a city councillor) contested the city electorate, while G.T. London, later mayor of Petone, stood in the Hutt seat. ${ }^{61}$ Protesting the apparent hegemony of the skilled workers, the city's seamen and wharf labourers nominated MacDonald, George Fisher (the Liberal incumbent) and Robert Winter (former member of the Canterbury ASRS executive) as an alternative ticket. Attempts to unify the competing factions failed, and on 5 December Wellington voters had the opportunity to support five labour candidates. ${ }^{62}$

Under the aegis of the United Labour Election Committee (ULEC), Auckland trade unionists released a political platform on 1 November 1890 . Written by the radical journalist Arthur Desmond, the manifesto endeavoured 'to make our island home an island Commonwealth' by emancipating labour through a series of 'clearly defined proposals for reform'. The five-point programme called for a one per cent land tax to replace the existing property tax; an end to Crown land sales; a minimum wage attached to all government contracts; railway management reform; and the institution of a State Bank of Issue. ${ }^{63}$ As in Christchurch, the labour and Liberal parties maintained close associations. Desmond was a protégé of Sir George Grey, and on 12 November the ULEC voted unanimously to support Grey's Central Electioneering Committee, and agreed to select a joint ticket to contest the city electorate - alongside Grey (who retired from public life on 24 November, replaced

\footnotetext{
${ }^{61}$ T.K. MacDonald's selection (given his involvement in the Petone Woollen Mill dispute) appears surprising, yet he had ingratiated himself with the TLC by refusing to join the Wellington Employers' Association in late August, and later donating 'an allotment of land in the city suitable for the erection of a cottage home' as a prize in a TLC fundraising raffle. Campbell, 'Parties and Special Interests in New Zealand', pp.35-36; 'Notes on Candidates Endorsed by Trade Unions and Labour', 1890, Roth Papers, MS-Papers 94-106-29/04, ATL.

${ }^{62}$ Campbell, 'Parties and Special Interests in New Zealand', p.45.

${ }^{63} \mathrm{NZH}, 1$ November 1890, p.5.
} 
by the manufacturer J.M. Shera), they selected two lawyers, W.L. Rees and W.J. Napier. $^{64}$

\section{Climbing the Hustings:}

John Ballance returned to Whanganui to begin his election campaign immediately after the parliamentary session ended on 17 September. His urgency was motivated by the desire to gain an early advantage over his opponents. Custom dictated that the premier open the election campaign, but Atkinson's heart condition prevented him from campaigning until early November. ${ }^{65}$ Opening with a speech at the Oddfellows' Hall on 23 September, Ballance defended his policy in Opposition, attacked the record of a 'dead' government, and outlined the legislative programme of a future Liberal administration. ${ }^{66}$ Unsurprisingly, the cornerstone of Ballance's agenda was land reform, the sine qua non of individual and colonial improvement. Land monopolists bore the brunt of his ire: 'As sure as night follows day, so sure will it be found that these estates will be subdivided and disposed of, and for every one man at present there will be ten in the future' ${ }^{67}$ Ballance offset his radical, double pronged attack (via graduated taxation and compulsory purchasing schemes) on the wealthy, with an equivocal stand on the colony's labour troubles. Although he 'strongly condemned' the Railway Commissioners' draconian response to dissent, he emphasised the undesirability of the Maritime Strike and the consequent necessity of a state arbitration system. Displaying a populist streak, Ballance noted with pride that his Opposition had united with the 'skinflints' to force retrenchment on the

\footnotetext{
64 'Notes on Candidates Endorsed by Trade Unions and Labour', 1890, Roth Papers, MS-Papers 94106-29/04, ATL; NZH, 12 November 1890, p.5; Rachel Barrowman, 'Desmond, Arthur fl.1884-1894', Dictionary of New Zealand Biography; available from http://www.dnzb.govt.nz/dnzb/alt_essayBody.asp?essayID=2D9; accessed 14 August 2010.

${ }^{65}$ Bassett, Sir Harry Atkinson, p.160.

${ }^{66}$ GRA, 26 September 1890, p.4.

${ }^{67}$ Yeoman, 27 September, no page, in McIvor, The Rainmaker, p.172.
} 
government. Concluding the address, he stressed the unity and discipline within the Liberal ranks - alluding to the fractured government and the necessity of strong, stable leadership. ${ }^{68}$

The premier's silence, and public uncertainty regarding the election date muted the press response to Ballance's speech. ${ }^{69}$ However, initial impressions served as a useful political barometer. Although the Evening Post criticised the Atkinson Government, the paper showed little affection for John Ballance. Earlier in the year it had described his leadership as 'very disorganised' and on 24 September reported that Ballance's speech 'contain[ed] nothing to induce even the most strenuous opponent of the present Government to cherish a hope that any improvement in policy or administration' would ensue if he became premier. ${ }^{70}$ When the Wanganui Herald defended Ballance's actions, the Post accused the paper of playing 'Mr. Puff' and 'interpreting the meaning behind' the Opposition leader's oracular comments. ${ }^{71}$ The Press expressed similar sentiments, deriding Ballance for hiding his deficiencies behind the 'old quack nostrum of graduated land tax'. Yet, the paper's management was split between the desire to scare voters away from the Liberals and fostering disharmony within the party's ranks. In the week after Ballance began his campaign, the Press accused him of giving 'his approval to the proceedings of the Trade Unionists', yet drew attention to the disjuncture between his 'large professions of sympathy' with the embattled unionists, and his equivocation over the origins of the Maritime Strike. $^{72}$

For most newspapers, Ballance delivered his speech into a political vacuum. The Maritime Strike still monopolised headlines, and following the close of the

${ }^{68}$ GRA, 26 September 1890, p.4.

${ }^{69}$ Cabinet pledged to hold the election before 12 November, but on 3 October it announced that the election would be held on 5 December. EP, 3 October 1890, p.2.

${ }^{70} E P, 29$ March 1890, p.2; EP, 24 September 1890, p.2.

${ }^{71}$ EP, 1 October 1890, p.2; Yeoman, 4 October 1890, no page, in McIvor, The Rainmaker, p.174.

72 Press, 25 September 1890, p.4; Press, 1 October 1890, p.4. 
parliamentary session, the press anticipated the collapse of the hastily arranged labour conference. Few candidates began campaigning so soon after Parliament had adjourned, and confusion reigned regarding the cohesion of the Liberal 'party' and the role of labour in the election. The New Zealand Herald framed the election as a contest between two roughly formed parties, postulating that 'the victory of the Opposition would be a period of office for Stout, Ballance, Fish [member for Dunedin South], Fisher [member for Wellington East], and Seddon' ${ }^{73}$ Emphasising the fragility of the Liberal-labour axis, on 2 October the Herald introduced a regular column informing readers of the alignment of all candidates standing for election. Ignoring the factional nature of Atkinson's government, the Herald aggregated conservative candidates under the monolithic bloc of 'Government Supporters', while offering separate listings for 'Oppositionists', 'Labour' candidates, and those of either 'Independent' or 'Doubtful' political leanings. ${ }^{74}$ By contrast, the Otago Daily Times dismissed suggestions that organised parties had superseded factional politics, reporting that 'the total absence of well defined party lines...renders all political forecasts necessarily vague and unsatisfactory'. ${ }^{75}$

While Ian Merrett's claim that labour issues were incidental to the election is exaggerated, most newspapers struggled to arrive at a nuanced political framing of the colony's recent labour troubles. ${ }^{76}$ Early in the election campaign, the spectre of the Maritime Strike was unsophisticatedly portrayed as an insurmountable block to the political ambitions of organised labour. Many voters distrusted trade unions, yet the coincidence of significant electoral reform with the emergence of a powerful labour movement remained a phenomenon unexamined by contemporaries. The 1889

\footnotetext{
${ }^{73} N Z H, 27$ September 1890, p.4.

${ }^{74} \mathrm{NZH}, 2$ October 1890, p.5.

${ }^{75}$ ODT, 22 October 1890, p.2.

${ }^{76}$ Merrett, 'A Reappraisal of the 1890 Maritime Strike', p.197.
} 
amendments to the Representation Act had reduced the number of Pākehā MHRs from 91 to 70, primarily at the expense of urban seats, and increased the 'country quota' from 18 to 28 per cent. ${ }^{77}$ Yet, George Grey's 'one-man, one-vote' provision eliminated almost 30,000 multiple registrations, a change significant enough to shift the balance of power against presumably conservative landholders in marginal seats such as New Plymouth, Wanganui, Waitotara, and Masterton. ${ }^{78}$ Regardless of the strike's outcome, the surge in trade union membership had created powerful urban voting blocs that would influence the outcome of a tight election. Whether out of naïveté, or the desire to suppress or ignore the ambitions of the politically ambitious unionists, the metropolitan newspapers rarely presented their readers with useful analyses of the changing political environment.

The New Zealand Herald editorial on 4 October exemplified newspapers' underestimation of labour politics. While surprised by the level of labour participation in the election campaign, the paper suspected it would prove futile, as the Maritime Strike had aroused reactionary sentiments 'throughout every constituency'. Reminding undecided voters of the complicity between labour and the Liberals, the paper noted "so far as the "labour party" have any influence it will be given to the Opposition'. ${ }^{79}$ In a similar vein, the Otago Daily Times argued that organised labour had rejected 'humanitarian reforms' in favour of 'imaginary ideals' aimed at provoking social revolution. Labour leaders' aggression 'towards the whole community outside unionism' suggested that 'the election [would] naturally turn to a large extent upon issues arising out of the strike' ${ }^{80}$ The Grey River Argus refrained

\footnotetext{
${ }_{77}^{71}$ Alan McRobie, New Zealand Electoral Atlas, Wellington: GP Books, 1989, pp.7, 54-57.

${ }^{78}$ I thank Dr Brian Easton for providing access to his forthcoming monograph. Brian Easton, Not in Narrow Seas: New Zealand History from an Economic Perspective (unpublished manuscript, 11 September 2010); Luke Facer, 'The Introduction of Income Tax in New Zealand', Auckland University Law Review, Vol. 12, 2006, pp.66-67; Goldsmith, We Won, You Lost, p.82.

${ }^{79} \mathrm{NZH}, 4$ October 1890, p.4.

${ }^{80}$ ODT, 24 October 1890, p.2.
} 
from emphasising the futility of organised labour's ambitions, if only because it believed that 'the dark horse of the labor party is not yet in evidence - it may never be, even, though there is no scarcity of time in which to make political combinations'. 81

Newspapers adopted a similarly acerbic tone on the rare occasions on which they published commentaries on organised labour's political agenda. In a long editorial on 6 October, the Evening Post concurred with the Wellington TLC's diagnosis of the colony's problems - specifically 'population exodus', 'the disturbed relations between labour and capital', and the necessity of preventing another term of 'illjudged legislation and inefficient administration'. The paper accepted the necessity of land and taxation reforms to end 'the aggrandisement of the few at the expense of the many', but rejected the cessation of Crown land sales. Industrial protection and immigration restriction were deemed economically disastrous, while progressive taxation would unfairly burden capitalists and slow the economy. Similarly, the Post argued that the demand for an elected Legislative Council displayed the unionists' 'want of acquaintance with the principles of representative government and constitutional law'. Discouraging readers from electing radical candidates, the paper concluded by listing its ideal parliamentarian: 'He must be able to command the respect and confidence of other members, or his influence...is likely to be very small, and his power in Parliament a myth' ${ }^{82}$

Consistent with its earlier division of organised labour into two disparate factions, on 18 October the New Zealand Herald examined the 'split' between the colony's 'best working men' and their leaders. The paper argued that the Maritime Strike alienated the majority of 'unionists pure and simple', who were now 'very sceptical

\footnotetext{
${ }^{81}$ GRA, 15 October 1890, p.2.

${ }^{82} E P, 6$ October 1890, p.2.
} 
about labour leaders and labour candidates'. By contrast, the Herald depicted labour leaders as avaricious anarchists, eager to 'destroy land values...[and] rob the present owners by means of a land tax'. ${ }^{83}$ The Press concurred, arguing that having failed to crush local industries, union leaders seemed 'bent upon trying their hand on the agricultural community', while the Otago Daily Times believed they leaned 'towards social revolution'. ${ }^{84}$ The accusations were misleading - land reform was an urgent concern, championed by the press, the Opposition, and many in government. ${ }^{85}$ That the Herald and Press considered the 'land question' an unpopular attack on the wealthy testified to the dogmatic conservatism of the papers' management, and their alienation from the wider electorate.

Although campaigning began in late September, detailed accounts of candidates' speeches rarely featured in the press. Editors, however, made exceptions for candidates whose rhetoric aligned with their ideological sensibilities. When Edwin Jellicoe, an independent candidate in the Wellington electorate, delivered a speech at the Opera House on 15 October, the Evening Post reprinted his criticism of the Maritime Council and ran an editorial praising his 'masterly' assessment of the recent strike. Jellicoe, an ex-adviser to John Millar, criticised the actions of his former associate, arguing that Millar had prolonged the New Zealand strike on Australian orders. ${ }^{86}$ Although Jellicoe was unlikely to win one of the Wellington seats, the New Zealand Herald also deemed his address worthy of publication. On 16 October the paper reported on the speech, emphasising his scorn for 'the actions of J.A. Millar

\footnotetext{
${ }^{83} \mathrm{NZH}, 18$ October 1890, p.4.

${ }^{84}$ ODT, 24 October 1890, p.2; Press, 17 October 1890, p.4.

${ }^{85}$ Tom Brooking argues that 'every other political issue including relations between capital and labour...was of lesser importance [than land reform]'. Brooking, Lands for the People?, p.81. Editorials in the Evening Post, Grey River Argus, Lyttelton Times, and Otago Daily Times all supported legislative efforts to promote closer settlement of the land. EP, 6 October 1890, p.2; GRA, 17 October 1890, p.2; LT, 19 September 1890, p.4; ODT, 9 October 1890, p.2.

${ }^{86} \mathrm{EP}, 16$ October 1890, p. 2 .
} 
with regard to the labour difficulty' ${ }^{87}$ In Christchurch, the Press utilised a similar tactic, publishing a speech critical of organised labour given by the former Minister of Justice, William Rolleston. Claiming that he could see no reason for the strike, Rolleston argued that trade unions had 'gone outside...the course laid down by the best men who had been foremost' in their formation. ${ }^{88}$ Two days later, the paper's editorial praised Rolleston's tough stance on organised labour and reiterated its condemnation of the Maritime Council's decision to instigate and prolong the Maritime Strike. $^{89}$

\section{Demonstrating Solidarity:}

The advent of a colony-wide labour 'Demonstration Day' on 28 October offered a brief respite from the slow building coverage of the election campaign. Prompted by the European and American May Day demonstrations organised at the Second International, in May the Maritime Council instituted a holiday to celebrate the achievements of New Zealand workers. ${ }^{90} 28$ October 1890 was not only the first anniversary of the Council's formation, but also the fiftieth anniversary of Wellington workers' proclamation that ' 8 hours shall be the working day, and that anyone offending shall be ducked in the harbour'. ${ }^{91}$ 'Eight-hour' demonstrations had been held in Auckland and Dunedin during the early 1880s, yet falling attendances saw annual parades abandoned in $1887 .^{92}$ Premier Atkinson gazetted a notice closing all government offices for the day, but Demonstration Day was not a public holiday. While councils in Wellington, Christchurch, and Dunedin afforded workers a day's

${ }^{87} \mathrm{NZH}, 16$ October $1890, \mathrm{p} .5$.

${ }^{88}$ Press, 25 October 1890, p.6.

${ }^{89}$ Press, 27 October 1890, p.4.

${ }^{90}$ Gita Deneckere, Marie-Louise Goergen, Inge Marssolek, Danielle Tartakowsky, and Chris Wrigley, 'May Days', in Jean-Louis Robert, Antoine Prost, and Chris Wrigley (eds.), The Emergence of European Trade Unionism, Aldershot: Ashgate, 2004, pp.141-65.

${ }^{91}$ Bollinger, Against the Tide, p.41.

${ }^{92}$ Bert Roth, 'Labour Day in New Zealand', in John E. Martin and Kerry Taylor (eds.), Culture and the Labour Movement, Palmerston North: Dunmore Press, 1991, pp.305-07. 
holiday as a gesture of goodwill, employers pressured the Auckland TLC to postpone the demonstration until the Prince of Wales' Birthday on 10 November. Furthermore, by late October the impending collapse of the Maritime Strike cast a pall over the planned festivities. Nevertheless, the Demonstration Day proceedings were not the funerary march that Neill Atkinson uncharitably described. ${ }^{93}$ Held six weeks before the election, labour leaders believed that the celebrations gave workers an opportunity to 'assert their moral and political equality by peacefully organising public space'. Well-organised public spectacles demonstrating workers' unity, respectability, and decency would counteract the misconception that the working classes were idle, drunk, and degenerate..$^{94}$

Despite the Maritime Council's best intentions, elements within the press remained wary of organised labour. The Evening Post believed that the spectre of the strike altered the tone of the festivities. When the Council deliberated a labour holiday in May, 'the aims of Trade Unionism, so far as they were apparent to the public were legitimate'. By attacking the colony's industrial base, the Post reminded readers that unions had jeopardised their tenuous claim to legitimacy. Accordingly, the events of 28 October were considered an unwelcome reminder of a 'struggle entered upon without justification, directed without wisdom, illegitimate in its object, [and] hopeless from its very inception'. ${ }^{95}$ The Otago Daily Times hoped the holiday would serve as 'a symbol of peace', but dismissed trade unionism as 'little more than...a power for working mischief'. Undermining its assertion that the demonstration signalled a positive future for unionism, the paper identified the

\footnotetext{
${ }^{93}$ Atkinson, 'Against the Tide', in Walsh (ed.), Trade Unions, Work and Society, p.78.

${ }^{94}$ Olssen, Building the New World, p.177.

${ }^{95}$ EP, 27 October 1890, p.2.
} 
exclusion of bankers, company directors, and merchants from the Dunedin parade as evidence of 'the existence of a schism' within the labour movement. ${ }^{96}$

Aware of the scrutiny that public demonstrations attracted, labour leaders worked tirelessly to ensure the day's success. Workers across the country participated in street parades, sports, and variety concerts - a morale boosting show of vitality amid hard times. Over 3,000 workers joined the parade in Dunedin, each trade marching in work clothes under its own banner. Later, 11,000 attended the sports and banquet held at the Caledonian Ground. Christchurch unionists turned out in equal force, with 2,000 workers marching to Addington, where 8,000 enjoyed a day of sports and dancing. ${ }^{97}$ In Wellington, 1,500 workers marched from the Government Buildings to Newtown Park, led by Samuel Parnell, the 80-year-old founder of the eight-hour movement, while 'pride of place' was given to local Maritime Council members. ${ }^{98}$ Before a crowd of 4,000 in Newtown, Parnell argued for 'a more equitable distribution of wealth and a consequent enjoyment of the world by bona fide producers'. Reporting on the procession, the Evening Post eschewed the bitterness of its prior editorial, describing the day's events as 'successful'. 99 The Lyttelton Times was more effusive, arguing that the 'unexpectedly complete success of the Labour holiday' demonstrated the best attributes of trade unionism, while employers' acquiescence with the celebrations displayed the stability of New Zealand society. ${ }^{100}$

\section{An Election Without Issues?}

Hopes that the peaceful demonstrations would engender a sense of goodwill towards trade unionism were soon dashed. Unable to find fault with the Demonstration Day

\footnotetext{
${ }^{96}$ ODT, 28 October 1890, p.2.

${ }^{97} \mathrm{EP}, 29$ October 1890, p. 2.

${ }^{98}$ Bollinger, Against the Wind, p.42.

${ }^{99}$ EP, 29 October 1890, p.2.

${ }^{100}$ LT, 29 October 1890, p.4.
} 
celebrations, the press renewed its criticism of organised labour's increased political engagement. On 29 October, a meeting held at the Wellington Opera House by the independent candidate John Duthie disbanded 'amidst great confusion' as sections of the audience refused to let him speak. In an editorial the following day, the Evening Post mourned the absence of the 'spirit of fair play' that tempered the excesses of even the rowdiest 'British mob'. Arguing that the 'uproar was evidently the result of organisation', the paper claimed the 'leaders of the falsely so-called labour party' were responsible, a charge labour leaders denied. ${ }^{101}$ Despite admitting that the purported instigators of the unrest 'had not the courage to appear personally on the scene', their complicity went unquestioned by the Post, which urged 'the respectable portion of the electorate...to assert their strength' by repudiating labour candidates. ${ }^{102}$ A masterpiece of insinuation, the report implicated organised labour in an orchestrated attempt to sabotage a political meeting, without providing evidence to support the accusation. On 31 October, the Grey River Argus provided a less sensational account of the meeting, described from the outset as 'particularly lively'. Its report noted that jeering began after Duthie had 'raised the wrath of a large section of the audience' by attacking popular Liberal candidate George Fisher, a detail omitted by the Evening Post. ${ }^{103}$ Other reports implicated Duthie's supporters in the fracas; during the disruption they mounted the stage, cheering and waving their hats and handkerchiefs - further enraging the audience. ${ }^{104}$

In the days following Duthie's address, the Evening Post's sensational framing set the tone for press coverage of the incident. In an article entitled 'The Tactics of the Labour Party', the New Zealand Herald published selections from editorials on the

\footnotetext{
${ }^{101} E P, 30$ October 1890 , p.2; EP, 12 November 1890 , p.4.

${ }^{102} E P, 30$ October 1890 , p.2.

${ }^{103}$ GRA, 31 October 1890, p.4.

${ }^{104}$ ODT, 30 October 1890, p.2.
} 
fracas, intended to display the 'intensity of disgust' the disturbance had provoked. ${ }^{105}$ While the Press admitted that the 'circumstantial correctness' of its report could not be verified, it expressed satisfaction that unionists had revealed the division between themselves and those who represented 'law and order'. Once aware of the unionists' anarchic intent, the paper argued that 'every lover of fair play, good order, and sound legislation' was duty bound to vote against 'any man who seeks the labour vote'. ${ }^{106}$ Reporting on a similar interruption to a Dunedin meeting, the Otago Daily Times believed 'the recent disturbances' represented a vulgar new trend. The only solace to be taken from the incident was the satisfaction 'that they [the labour party] will pay the penalty for these offences at the polls'. ${ }^{107}$

The disruption of a Wellington public meeting was easily construed as metonymic of wider colonial problems. The incident confirmed established public prejudices about labour. These prejudices were exploited in order to portray the Wellington 'rowdies' as representative of their class and its anarchic intent. Newspapers eagerly constructed binary oppositions between the 'organised rowdyism' exhibited by purported trade unionists, and a set of idealised colonial values - 'fair play', class harmony, courtesy, moderation, and orderliness - embodied by the aggrieved Duthie. ${ }^{108}$ The definition of a desirable New Zealand character broke with previous coverage of labour issues in 1890. During the unrest of the preceding six months, newspapers emphasised the objectionable aspects of the labour movement - self-interest, radicalism, class antagonism, ignorance, and greed - yet

\footnotetext{
${ }^{105}$ NZH, 31 October 1890, p.6.

${ }^{106} \mathrm{ibid}$. Despite extensive searching, I have been unable to find the original reference.

${ }^{107} O D T, 31$ October 1890, p. 2 .

${ }^{108} \mathrm{NZH}, 31$ October 1890, p.26. A similarly idealised character was articulated in nineteenth century New Zealand literature. In her study of novels written between 1860 and 1914, Lesley Murrihy identifies the archetypal New Zealand hero as honourable, industrious, unpretentious, and egalitarian 'scrupulous in his populist denial of the importance of class - of class conflict and excessive distance, that is'. Belich, Making Peoples, p.403; Lesley Ruth Murrihy, 'The Myths and the Portrayal of New Zealand National Character in Nineteenth Century Pioneer Novels', MA thesis, Victoria University of Wellington, 1984, pp.64-93.
} 
failed to articulate viable alternatives. ${ }^{109}$ Faced with a reminder that the mass politics of new unionism had not faded with the demise of the Maritime Strike, newspapers reacted by accentuating the threat to an orderly society. Whether the disruption of Duthie's meeting was planned or simply the response of a hostile crowd to a candidate's misjudgement, the reaction to the incident emphasised elite fears regarding demotic politics. As during previous industrial disputes, the working classes were characterised as malleable and ignorant, just as easily swayed by deviant agitators as they were influenced by the exemplary conduct of men like Duthie, or indeed, newspaper editorials.

The horrified response to the interruption of a minor political address also revealed the unease wrought by the absence of strong political leadership during a period of uncertainty. Following the end of the parliamentary session, Premier Atkinson 'seemed to have withdrawn from political reality altogether'. He contested the Egmont seat without enthusiasm; prevented from campaigning by his heart condition, Atkinson secluded himself at his New Plymouth estate. ${ }^{110}$ On 6 November, 45 days after John Ballance began his campaign, the premier released his election manifesto to the press. In a lengthy address, Atkinson reminded voters of the government's achievements: the conversion of a $£ 500,000$ deficit into a $£ 36,500$ surplus in three years, reducing the number of MHRs from 95 to 74, promoting closer land settlement, freeing the railways from political interference, and fostering closer relations with the Australian colonies. On the Maritime Strike, Atkinson subscribed to the consensus interpretation, stressing the 'danger and unwisdom of our local unions being so connected with outside associations'. Atkinson's rhetoric was tired

\footnotetext{
${ }^{109}$ The formulation of 'negative' rather than 'positive' images of New Zealand society was a staple of political rhetoric. David Hamer notes that nineteenth century politicians emphasised 'escaping', 'avoiding', and 'preventing' old-world problems, defining what New Zealand should not be. Hamer, The New Zealand Liberals, p.55.

${ }^{110}$ Bassett, Sir Harry Atkinson, p.160.
} 
and regressive - the difficulties of leading a fractured government had exhausted his desire for reform. If elected, he pledged 'to steadily follow the course we have entered upon', promising no further retrenchment, no additional spending, no taxation reform, and no labour legislation. Instead, he presented the absence of 'political or financial fireworks' as an exercise in prudence and virtue. ${ }^{111}$

Sir Harry Atkinson's bland manifesto provoked fierce reaction in the press. Conservative newspapers lauded Atkinson's muted approach as a necessary corrective to the turbulence of the previous year. The Press believed that 'the great majority of colonists' shared his aversion to 'sensational proposals', and lauded a manifesto 'worthy of the author and the occasion'. Yet the paper offered little comment on Atkinson's future plans, instead using its editorial to praise the austerity he displayed during his tenure as Treasurer, and offer its support in obstructing the 'revolutionary project' of taxation reform. ${ }^{12}$ Casting Atkinson's apathy as expediency, the Otago Daily Times argued that his late entry into the election campaign limited the 'agony of electioneering' suffered in 1887. For the Daily Times, his caution represented a healthy medium between the 'skinflints' and the Liberals. While admitting that Atkinson's policy was 'excessively stolid', the paper recognised the impediments to further retrenchment and the necessity of future borrowing, and hailed the manifesto as 'a piece of statecraft such as no other man in the colony could give us'. ${ }^{113}$ Despite his much-admired prudence, Atkinson attracted criticism from the 'skinflint' right. While the New Zealand Herald branded his address 'the most important manifesto of the impending electoral campaign', it expressed concern that

\footnotetext{
111 ibid.; ODT, 6 November 1890, p.4.

112 Press, 7 November 1890, p.4.

${ }^{113}$ ODT, 7 November 1890, p.4.
} 
without future retrenchment and tax cuts, the colony would suffer another exodus of settlers and capital. ${ }^{114}$

For the liberal press, the premier's manifesto bespoke his age, health, and diminishing political influence. The Lyttelton Times believed the address revealed a man 'without health, without heart, [and] without party'. Reviewing a woeful final year in office, the Times dismissed Atkinson's parsimony as a smokescreen for his 'feeble conservatism'. ${ }^{115}$ The Grey River Argus treated Atkinson with greater hostility, accusing him of giving 'no indication whatever that...legislation of any kind can improve the position of the colony'. Frustration with his taxation policy, rather than his approach to labour issues, predominated, with the paper branding his opposition to income taxation a ploy to 'spare the pockets of [his] friends - the landholders'. ${ }^{116}$ The premier's reluctance to address the 'land problem', either by legislation or implementing punitive taxation provided another focal point for his detractors. His satisfaction with the colony's 'gradual' settlement was seized upon by the Evening Post as evidence of his isolation from the electorate. Lambasting his administration's 'failure to provide means for gratifying...[settlers'] earnest desire' to settle the land, the paper argued that he would best serve the colony by leading the Opposition. ${ }^{117}$

Although the antagonistic spirit engendered by the premier's opening address reinvigorated coverage of the election campaign, labour issues were overshadowed by the colonial obsession with land. Given the preponderance of union-backed candidates in the Wellington city electorate, the TLC manifesto surprisingly omitted

\footnotetext{
${ }^{114}$ NZH, 6 November 1890, p.4.

${ }^{115} L T, 6$ November 1890, p.4.

${ }^{116}$ GRA, 8 November 1890, p. 2 .

${ }^{117} E P, 6$ November 1890 , p.2; EP, 8 November 1890 , p.2.
} 
eight-hour or compulsory arbitration legislation. On the hustings, candidates focussed on 'breaking' the estates. In speeches featured in the Evening Post on 7 and 15 November, T.K. MacDonald addressed the 'land question' - advocating for the acquisition of 'vast tracts' of Māori land and criticising the government's failure to prevent wealthy speculators from elevating land prices beyond the reach of smallholders and settlers. ${ }^{118}$ Land reform also dominated the agendas of the Wellington TLC's other candidates, F.H. Fraser and William McLean. At his first electoral address on 13 November, Fraser's remarks predominantly concerned graduated land taxation, land nationalisation, and education reform, followed by a cursory endorsement of any future eight-hour legislation. ${ }^{119}$ Following the example of his fellow candidates, William McLean also neglected to mention the Maritime Strike, instead reiterating the consistency of his support for land reform and accusing Atkinson of putting the colony 'entirely at the mercy of those who owned the greater part of the wealth'. ${ }^{120}$

Mirroring the impact of the Maritime Strike, the salience of 'traditional' labour issues to the election varied regionally. While North Island labour candidates directed their ire at already unpopular targets - the premier and his wealthy supporters labour politicians assumed more combative roles in Christchurch and Dunedin. These tactics were partially stimulated by their location in electorates with larger populations of trade unionists, but also emerged as a response to greater press hostility. However, as W.J. Gardner has noted, Canterbury candidates were hardly loquacious about industrial relations. ${ }^{121}$ At PPA meetings, Reeves, Perceval, and Taylor routinely described themselves as 'thorough believer[s] in Unionism' as a

${ }^{118} E P, 7$ November 1890, p.2; EP, 15 November 1890, p.4.

${ }^{119}$ EP, 13 November 1890, p.4.

${ }^{120}$ EP, 18 November 1890 , p.4.

${ }^{121}$ In a survey of political speeches in the Lyttelton Times, Gardner found that only 15 of 27 candidates standing for election in Canterbury mentioned industrial relations. Gardner, Prelude to Arbitration, p.120. 
vehicle for working-class empowerment, despite expressing their reservations with the strike as a bargaining tactic. ${ }^{122}$ Hoping to destabilise the popular ticket, the Press eagerly reported on inconsistencies in their political pronouncements. On 18 November, the paper attacked Taylor's proposed foreign bondholders tax. Dredging up Reeves' statement that anyone considering the idea 'ought to be booted out of the country', the paper accused him of hypocrisy for standing on a ticket that included Taylor. ${ }^{123}$ Speaking the following day, Reeves reaffirmed the solidarity of the PPA ticket. Turning on the Press, he boasted that if the foreign bondholders' tax was the largest division it could discern amongst the trio 'it shewed...that for all practical purposes the three gentlemen who had come together to carry the Christchurch seats were united in opinion'. ${ }^{124}$

The Press' attempt to split the liberal vote in Christchurch justified William Pember Reeves' fears. As editor of the Lyttelton Times, he opposed the formation of an independent 'labour party', warning against the dilution of the left-leaning vote. He justified the PPA's decision to ask the electorate to return all three candidates with the argument that his opponents 'ask for the votes of Liberal electors, but [stand] consciously or otherwise - in the conservative interest' ${ }^{125}$ Reeves also used the Lyttelton Times to attack rival candidates. Responding to a speech by the Ministerial candidate for Christchurch, E.W. Humphreys, Reeves declared that Humphreys had misled his audience by asserting that he had supported the failed Eight Hours Bill. 'Unfortunately he did oppose it...[h]e was one of those who the session before last helped to kill it'. ${ }^{126}$ Reeves believed that the conservative influence extended beyond false claims of sympathy with trade unions. On 25 November, he published a robust

\footnotetext{
${ }^{122}$ Press, 1 November 1890, p.7; Press, 12 November 1890, p.3.

${ }^{123}$ Press, 18 November 1890, p.4.

${ }^{124}$ Press, 19 November 1890, p.7.

${ }^{125} L T, 13$ November 1890, p. 4 .

${ }^{126}$ LT, 20 November 1890, p.4.
} 
editorial defending the 'radical candidate' for Heathcote, William Tanner, from vicious rumours spread by 'unauthorised partisans'. The Lyttelton Times reported that a rumour had been circulating suggesting a vote for Tanner would effectively disenfranchise the electorate, as the other MHRs would not tolerate 'the presence among them of an artisan'. Dismissing the claim, the paper declared that any 'good, thoughtful, working-man candidate...has every right to appeal to any New Zealand constituency where he has friends'. ${ }^{127}$

While aspiring politicians assiduously avoided reference to the Maritime Strike, its spectre was felt strongly in Port Chalmers. In a symbolic re-enactment of the strike, the seat was contested by John Millar, the primary figure associated with the rise of new unionism, and James Mills, the incumbent member and Managing Director of the Union Company - the largest employer in the electorate. Millar stood reluctantly, either out of a sense of duty, or as an expression of defiance. Directed at 'working men', his speeches advocated Liberal land, taxation, and education policies, and he withheld comment on the strike. ${ }^{128}$ Neither his opponent nor the press shared such reticence. In a snide report on the Port Chalmers race, the New Zealand Herald asserted that 'the labour vote is not unanimous' and warned Millar 'that many of his apparent supporters are apparent only'. ${ }^{129}$ The Otago Daily Times contended that Millar ought to 'keep perfectly quiet' given his orchestration of a 'disaster upon the whole community'. Millar's candidacy saw him accused of using the strike as 'a stepping stone to personal advancement'. ${ }^{130}$ By contrast, Mills examined the strike at 'very great length', blaming Millar and his executive for fabricating a pretext to 'figh[t] capital', an outrage to be remedied with strict legislative restrictions on trade

${ }^{127} L T, 25$ November 1890 , p.4.

${ }^{128}$ ODT, 19 November 1890, p.4.

${ }^{129} \mathrm{NZH}, 17$ November 1890 , p.6.

${ }^{130}$ ODT, 20 November 1890, p.2. 
unions. ${ }^{131}$ Inevitably, the 'the most unpopular...man in New Zealand' lost to a man with 'almost feudal' ties to the electorate, yet Millar had proven to be as gifted a politician as he was an organiser. ${ }^{132}$ On 5 December he reduced Mills' margin of victory by two-thirds, and cultivated a core of loyal supporters that would see him take the seat in $1893 .^{133}$

\section{Calling out the Vote:}

In the week before the election, newspapers rallied support for favoured candidates while endeavouring to sabotage opponents' chances of election. Ever fearful of divisions emerging within the Liberal-labour coalition, the Lyttelton Times published the Canterbury TLC's manifesto on 1, 4, and 5 December. Instructing 'the workingmen of Canterbury' to vote for Liberal candidates, it argued that 'any division of the liberal party vote' would ensure a conservative victory. Only in solidarity could workers free themselves from 'the monster...then crush it out of existence'. ${ }^{134}$ William Pember Reeves reiterated the warning in emotive editorials on 4 and 5 December. The latter, addressed to 'Liberals of Canterbury!' reminded voters that Atkinson had placed the burden of taxation on the 'poorer classes', and 'locked up' the country 'against the toiling masses', prompting the exodus of 1888 . Reeves concluded by commanding liberals to do their 'duty' by voting for land, labour, and taxation reform. ${ }^{135}$

While the Lyttelton Times sought to heighten perceptions of the colony's stagnation, other newspapers dampened such fears, maintaining that consensus

\footnotetext{
${ }^{131} E P, 25$ November 1890, p.2.

${ }^{132}$ Gardner, Prelude to Arbitration, pp.122-23.

${ }^{133}$ In 1887, James Mills won the Port Chalmers seat with 985 votes to James Green's 281. In 1890, Mills won with 874 votes to Millar's 647. 'The General Election', AJHR, 1887, H-13, p.3; 'The General Election, 1890', AJHR, 1891, First Session, H-2, p.2.

${ }^{134} L T, 1$ December 1890, p.6; LT, 4 December 1890, p.5; $L T, 5$ December 1890, p.4.

${ }^{135} L T, 4$ December 1890, p.4; $L T, 5$ December 1890, p.5.
} 
remained the default setting in New Zealand politics. The Otago Daily Times insisted that unlike the 1887 election, there was no 'real party fight going on' and 'no great questions of policy' to consider. Challenged by an Opposition caucus populated by 'the dregs of one of the worst Administrations New Zealand has known' in an election devoid of substance, the Daily Times asserted that the Atkinson Government was entitled to the confidence of the electorate. ${ }^{136}$ These sentiments were not confined to the conservative press; Atkinson's opponents offered comparable synopses of the campaign. The Grey River Argus mourned the 'sameness' of local candidates' speeches, in an 'almost monotonous' election. In the Grey constituency, voters were compelled to 'choose the least of two evils', as the paper found little between the two purportedly liberal candidates, save for personality. ${ }^{137}$ Similarly ambivalent, the Evening Post remarked, 'there is not really any political principle before the constituencies on the present occasion'. Dismissing the taxation debate as a matter of expediency on both sides, the paper nevertheless argued that 'the present ministry is not one which we think can...safely be continued in office'. ${ }^{138}$

If the conservative press were to be believed, radicals and agitators obstructed the colony's path to economic growth and social harmony. Under this paradigm, the popular clamour for land and taxation reform was dismissed as the invidious scheming of vengeful union leaders. Yet by early December, the conservatives realised that labour would influence the outcome of a tight election. Newspapers that had rejected the notion of cohesive political parties replaced condescending columns asserting the colony's revulsion against unionism, with warnings that portrayed the colony's loosely organised labour platforms as a threatening colony-wide coalition. On 3 December, the New Zealand Herald identified the emergence of 'Labour

\footnotetext{
${ }^{136}$ ODT, 5 December 1890, p.2.

${ }^{137}$ GRA, 2 December 1890, p.2.

${ }^{138} E P, 4$ December 1890, p.2.
} 
candidates' as a novel feature of the campaign. Led by 'King Millar', trade unionists were 'inexplicably' opposed to Sir Harry Atkinson, and saw land reform as a tool to cripple the wealthy. ${ }^{139}$ The Otago Daily Times described the 'party's' policy as the self-interested and antagonistic advancement of a working-class agenda, a singlemindedness that the paper had not identified in either the skinflints or the Railway Commissioners. ${ }^{140}$ Such arguments were wholly disingenuous; as Jim McAloon has noted, many wealthy candidates advocated liberal policies before and during the 1890 campaign. ${ }^{141}$ By identifying labour as the driving force behind the year's tribulations, editors maintained the fantasy that the status quo could, and would, survive.

Conservative panic coloured Election Day editorials. Despite ridiculing the PPA throughout the campaign, the Press worried that the Liberal-labour coalition would repeat its 1887 success, printing voting instructions above its final pre-election editorial. Fearing 'mistakes', the paper reminded electors to 'strike out' the names of 'the so-called "Liberal Trio", vote for the Ministerial candidates E.W. Humphreys and J.T. Smith, and 'not exercise their third vote'. ${ }^{142}$ The Herald published a similar guide, instructing readers to elect a ticket of two Ministerialists and three independents to represent Auckland. ${ }^{143}$ In Dunedin, the Otago TLC printed posters denouncing electors that did not 'Vote Straight For The [Labour] Ticket' as a 'Traitor To His Country'. ${ }^{144}$ Rather than instructing its readers on how to vote, the Otago Daily Times declared its fervent hope that 'the leaders of the Labour Party [would] not succeed in inducing the working classes to follow their mandates in the election'.

\footnotetext{
${ }^{139} N Z H, 3$ December 1890, p.4.

${ }^{140}$ ODT, 5 December 1890, p. 2.

${ }^{141}$ McAloon, No Idle Rich, pp.107-08.

${ }_{142}$ Press, 5 December 1890, p.4.

${ }^{143} \mathrm{NZH}, 5$ December 1890, p.4.

144 'Otago TLC Poster, 'To All Electors', 4 December 1890, Roth Papers, MS-Papers 94-106-61/07, ATL.
} 
Failing that, the paper urged the future administration to refrain from submitting 'their judgement to the dictation of the ring of labour leaders'. ${ }^{145}$

The election result came as a shock the following morning. Unpredicted by most, the electorate swung toward the Liberals, particularly in the South Island. However, the size of the swing was shrouded in confusion. Typically, newspapers that had favoured the Opposition over the incumbent government declared a Liberal victory. The Evening Post considered the result 'disastrous for the present ministry' which was 'clearly in a decided minority'. ${ }^{146}$ The Lyttelton Times went further, proclaiming that 'the people have proved true to Liberal principles, and have by a substantial majority declared against Sir Harry Atkinson'. ${ }^{147}$ Even the Otago Daily Times concurred, lamenting a result that indicated electors 'have not thought, they have merely felt' ${ }^{148}$ However, the New Zealand Herald refused to concede, asserting that 'the new house...will meet with the present ministry in office'. ${ }^{149}$ The Grey River Argus concurred, citing the re-election of the 'principle [sic] members of the Ministry' as an indication of Atkinson's likely return as premier. ${ }^{150}$

Amid the confusion, one feature remained constant: candidates endorsed by labour had achieved extraordinary success. Of the 38 candidates endorsed by unions and TLCs (26 of which were also endorsed by Liberal organisations), 19 were elected. ${ }^{151}$ Despite the joint endorsement of many of these candidates, the press emphasised the division between 'labour-leaning MHRs' and 'non-labour Oppositionists'. ${ }^{152}$ The Press divided the 35 confirmed Opposition MHRs into two

\footnotetext{
${ }^{145}$ ODT, 5 December 1890, p.2.

${ }^{146} E P, 6$ December 1890, p. 2 .

${ }^{147} L T, 6$ December 1890, p.4.

${ }^{148}$ ODT, 6 December 1890, p. 2 .

${ }^{149} \mathrm{NZH}, 6$ December 1890, p.4

${ }^{150}$ GRA, 8 December 1890, p.2.

151 'Notes on Candidates Endorsed by Trade Unions and Labour', 1890, Roth Papers, MS-Papers $94-$ 106-29/04, ATL.

${ }^{152}$ McAloon, No Idle Rich, p.107.
} 
categories, 20 members represented 'Labour' while the remaining 15 came from the traditional 'Opposition'. ${ }^{153}$ The Otago Daily Times used the same categories, but split the Liberal vote between 22 'Labour' members and 14 Oppositionists. ${ }^{154}$ Newspapers universally hailed the triumph of the 'labour party' without investigating the new members' biographies. Of the 19 labour candidates, just five were manual workers: T.L. Buick, a carpenter from Wairau; J.W. Kelly, a tailor from Invercargill; Earnshaw and Pinkerton in Dunedin; and Tanner in Christchurch. ${ }^{155}$

The press covered the 'labour party' inconsistently during the election campaign. The term entered the popular consciousness when newspapers imparted the Duthie incident with 'national' resonance. Labour politicians were no longer risible extremists, but representatives of a dangerous organisation with a cohesive agenda. Ironies abounded in this paradigm shift. Although a coherent parliamentary Opposition emerged in 1889 , no clearly defined political parties existed in New Zealand. Neither labour nor the Liberals could boast more than disaggregated local and regional electoral committees, whose aims and ambitions frequently conflicted. William Tanner later admitted 'there was no concert...or even mutual correspondence in 1890 before the election, and in $1891 \ldots$ we 5 [labour candidates] met for the first time' ${ }^{156}$ By crediting the existence of a 'labour party', newspapers awarded unions an honour that they refused to bestow on the Liberals. Furthermore, the land and taxation reform programme, which the conservative press offered as evidence of a radical agenda, was the cornerstone of Liberal policy. In reality, the reforms were conceived and promoted by the middle-class radicals and rural smallholders, backed by labour in return for support on industrial legislation. Nevertheless, the press

\footnotetext{
${ }^{153}$ Press, 6 December 1890, p.4.

${ }^{154}$ ODT, 6 December 1890, p.2.

155 Barry Gustafson, Labour's Path to Political Independence: the Origins and Establishment of the New Zealand Labour Party, 1900-19, Auckland: Auckland University Press, 1980, p.13.

${ }^{156}$ W.W. Tanner to J.D. Salmond, 6 October 1924, Roth Papers, MS-Papers 94-106-29/02, ATL.
} 
directed its criticism at a recognised enemy, the 'labour party', to avoid alienating a far larger segment of the population.

Parliament reopened on 23 January 1891, and in the weeks following the election intense speculation surrounded the composition of the new government. Defying pressure from John Ballance and the Lyttelton Times, Sir Harry Atkinson refused to resign. ${ }^{157}$ While Ballance planned his strategy from Whanganui, 'anti-Ballance forces' gathered in Wellington. Judith Bassett argues that they understood the implausibility of forming a government, but refused to capitulate until the House convened. ${ }^{158}$ Revising its earlier pessimism, on 9 December the Otago Daily Times thought it impossible that Ballance could assemble a majority, and called upon Atkinson to form a coalition government with moderate Liberals. ${ }^{159}$ Yet, in the weeks following the election Atkinson faltered, while the prospect of government engendered greater cohesion amongst the Liberals. Worried about losing the House, conservatives within Cabinet determined to 'strengthen' the Legislative Council 'before the Reds g[ot] into the saddle'. ${ }^{160}$ The plan, hatched months earlier, had the support of the Governor, Lord Onslow, who persevered with the proposed appointments in spite of public opprobrium. ${ }^{161}$

When Parliament met, the first order of business was the election of a Speaker. The Opposition candidate, William Steward, defeated the government nominee, William Rolleston, by 36 votes to 29. Edwin Mitchelson, the Minister of Public Works and Native Affairs, announced the resignation of the Atkinson Government,

\footnotetext{
${ }^{157}$ Bassett, Sir Harry Atkinson, pp.162-163; LT, 8 December 1890, p.4.

${ }^{158}$ Bassett, Sir Harry Atkinson, p.162.

${ }^{159}$ ODT, 9 December 1890, p.2.

160 John Hall to John Ormond, 15 December 1890, Hall Letter Book, p.236, in McIvor, The Rainmaker, p.179.

${ }^{161}$ On 17 January 1891, Lord Onslow received a petition with over 5,000 signatures protesting the rumoured appointments. Bassett, Sir Harry Atkinson, pp.164-65.
} 
leaving Ballance free to form a ministry. ${ }^{162}$ Ballance had spent the previous month deliberating his future administration, so his Cabinet was ready to be sworn in the following day. The new Cabinet bridged the political and geographic divides within the Liberal party, yoking small farmers and businessmen with labour-aligned members to create a robust government. In addition to the Premiership, Ballance assumed responsibility for the Treasury, Trade and Customs, and Native Affairs. William Pember Reeves received the Education and Justice portfolios, and Richard Seddon became Minister of Public Works, Mines, and Defence. The Otago farmer John McKenzie took the important posts of Lands, Immigration, and Agriculture, while from the Legislative Council, the Wellington lawyer Patrick Buckley was appointed Attorney General. Joseph Ward and A.J. Cadman received minor offices, and would be rewarded in future Cabinet reorganisations. ${ }^{163}$ Generally, the press buried their animosity in recognition of Ballance's organisational acumen. ${ }^{164}$ While the new Cabinet was sworn in, Onslow foreshadowed future problems for the Liberals, announcing the appointment of seven new Legislative Councillors, including Atkinson, who would become Speaker. ${ }^{165}$

While the election of a Liberal government improved the lot of working people, labour's position within the party remained tenuous. Timothy McIvor notes that the Ballance Cabinet 'was the most radical the country had seen' ${ }^{166}$ In June 1891, Reeves was given responsibility for the newly created Bureau of Industries (renamed the Department of Labour in 1892). Aided by his Chief Clerk Edward Tregear, Reeves introduced legislation concerning Shop Assistants, Coal Mines, Contractors'

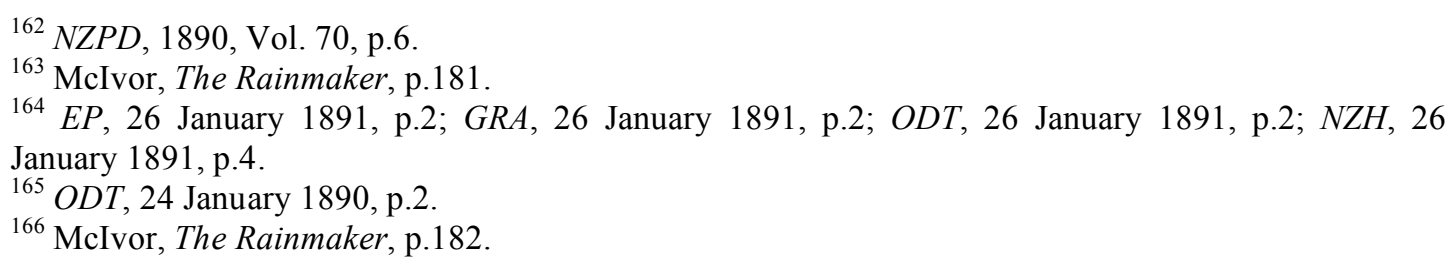


and Workmen's Lien, Factories, and Workmen's Wages. ${ }^{167}$ The Industrial Conciliation and Arbitration Act 1894 was the pinnacle of the Liberals' labour programme, yet its passage through the House testified to Reeves' determination in the face of an indifferent Cabinet. The Act, which provided for Conciliation Boards across the colony, and a three member Arbitration Court, made arbitration compulsory for all employers cited in disputes. While the Liberals' arbitration mechanisms would see New Zealand hailed as 'a country without strikes', Reeves fought for the Bill alone. ${ }^{168}$ Between 1891 and 1894 no other minister spoke to the bill, safeguarding their predominantly rural interests. ${ }^{169}$ Although Harry Holland and his allies later referred to compulsory arbitration as 'Labour's leg-iron', memories of defeat were raw in the 1890 s. ${ }^{170}$ In spite of their political success, the failure of the Maritime Strike left trade unions 'broken, flaccid, and penniless' - workers would not strike again until $1906 .^{171}$

Initially, the decision to embark upon a Liberal-labour alliance, rather than forming an independent labour party, as Australian unionists had, proved beneficial. Despite the lack of Cabinet unanimity on labour issues, Reeves had the support of Liberal votes to ensure the success of his legislative programme. Tregear fondly described the Liberals' first two terms in office as 'the Torchlight Procession'. Yet, with time, 'the torches burnt out'. ${ }^{172}$ The party drifted to the right, stalling reforms, and alienating the unions. The death of Ballance in April 1893, the installation of

\footnotetext{
${ }^{167}$ Roth, Trade Unions in New Zealand, p.20.

168 The title of Henry Demarest Lloyd's, A Country Without Strikes: A Visit to the Compulsory Arbitration Court of New Zealand, New York: Doubleday, 1900.

${ }^{169}$ There was one exception, on 4 October 1894 Seddon interjected in a Point of Order debate. NZPD, 1894, Vol. 82, p.965; Gardner, Prelude to Arbitration, pp.143-44.

${ }^{170}$ P.H. Hickey, "Red" Fed Memoirs, Wellington: New Zealand Worker Print, 1925, pp.4-6; H.E. Holland, Labor Leg-Ironed or Liberal and Labor Party Arbitration Acts in N.S.W. With Brief Reference to the New Zealand Arbitration Act, Wellington: The Maoriland Worker, 1912.

171 Harris Weinstock, Report on the Labor Laws and Labor Conditions of Foreign Countries in Relation to Strikes and Lockouts, Sacramento: W.W. Shannon, Superintendent State Printing, 1910, pp.118-19.

${ }_{172}$ Edward Tregear to J.D. Salmond, 9 December 1923, Roth Papers, MS-Papers 94-106-29/02, ATL.
} 
Richard Seddon as premier, and the 1893 election prompted this change of direction. Seddon did not share Ballance's politics, and his desire for 'moderation' marginalised the radical wing of the party. ${ }^{173}$ The doubling of the country Liberal contingent in 1893 strengthened Seddon's position, reducing the government's dependence on labour and bolstering its ties to rural interests. ${ }^{174}$ In February 1895, these cracks deepened, when Seddon suggested that trade unionists moderate their demands for further labour legislation, or risk jeopardising their cause. ${ }^{175}$ Although Reeves tried to downplay the speech, the Lyttelton Times suggested that "fear of "a reaction"...led [Seddon] to revise an important part of the policy of his Government'. ${ }^{176}$ Isolated by the Liberal hierarchy, on 10 January 1896 Reeves resigned his offices and left for London to take up the Agent-Generalship. The departure further weakened the Liberal-labour alliance. In 1897, for the first time, no minister attended the annual Trades and Labour Conference. ${ }^{177}$ Nevertheless, no alternative to the Liberal party emerged until the formation of the New Zealand Socialist Party in 1901, and the Independent Political Labour League in 1905.

\footnotetext{
173 R.T. Shannon, 'The Liberal Succession Crisis in New Zealand, 1893', Historical Studies of Australia and New Zealand, Vol. 8, no. 30, 1958, pp.183-201.

${ }^{174}$ McAloon, No Idle Rich, p.107.

175 R.T. Shannon, 'The Fall of Reeves, 1893-1896', in Chapman and Sinclair (eds.), Studies of a Small Democracy, p.136.

${ }^{176}$ LT, 11 February 1895, no page, in Shannon, 'The Fall of Reeves', in Chapman and Sinclair (eds.), Studies of a Small Democracy, p.138; GRA, 12 February 1895, p.4.

${ }^{177}$ Roth, Trade Unions in New Zealand, pp.22-23.
} 


\section{Conclusion}

The conviction that the New Zealand Maritime Strike began either in sympathy with or at the behest of Australian unionists is an enduring legacy of the press response to labour tensions in 1890. Furthermore, newspapers' insistence that domestic troubles arose from foreign meddling, rather than internal disharmony, altered public perception of the strikers and coloured political rhetoric during the election campaign. Contrary to popular perceptions about the ephemeral nature of news, the anti-labour narrative fostered by the press permeated the historiography of the Maritime Strike. Then, as now, newspapers selectively represented reality, emphasising events and ideas congruent with their political agendas, and omitting contradictory narratives. Evaluating the strike in 1891, W.T. Charlewood argued, 'it was plainly the policy of the labour party to help their brethren in Australia'. Twenty-five years later, J.D. Salmond echoed the sentiment: 'In this dispute the workers of New Zealand had no direct interest'. ${ }^{2}$ Although Ian Merrett demonstrated that Salmond and others had 'arrived at a gross mis-representation of events' by relying on partisan newspaper coverage, the consensus interpretation continues to attract advocates. ${ }^{3}$ Many histories gloss over the strikers' motives, content to rehash Salmond's conclusions. ${ }^{4}$ This thesis has addressed Merrett's concerns, assessing the coverage of the labour movement in 1890 in six metropolitan newspapers as the remarkable rise of trade

\footnotetext{
${ }^{1}$ Charlewood, 'Labour Troubles in New Zealand', p.714.

2 Salmond, 'The History of the New Zealand Labour Movement', p.61.

${ }^{3}$ Merrett, 'A Reappraisal of the 1890 Maritime Strike', p.239.

${ }^{4}$ Atkinson, 'Auckland Seamen and their Union', p.78; Waldo Hilary Dunn and Ivor L.M. Richardson, Sir Robert Stout: A Biography, Wellington: A.H. \& A.W. Reed, 1961, p.132; Easton, Not in Narrow Seas (unpublished manuscript, 11 September 2010); Sinclair, A History of New Zealand, p.169. These arguments have also influenced popular understandings of the strike, as evidenced by their airing in a recent Radio New Zealand National programme on the history of trans-national labour organisation. Jeremy Rose, Ideas: Globalised Labour, Radio New Zealand National, 24 October 2010. However, it is important to recognise that some historians have repudiated the 'Australian orders' interpretation in favour of more nuanced interpretations of the strike. See Bennett, 'Rats and Revolutionaries', pp.3536; Gardner, Prelude to Arbitration, p.116; McLean, The Southern Octopus, pp.109-15; Mitchell, 'John Andrew Millar and the New Zealand Labour Movement', pp.50-55; Olssen and Richardson, 'The New Zealand Labour Movement, 1880 - 1920', in Fry (ed.), Common Cause, p.4.
} 
unionism soured in a climate of increasing industrial tension, capitalist countermobilisation, political opportunism, and hostile reportage.

The Maritime Council emerged during a period of economic uncertainty, and aligned New Zealand workers with broader trends in the international labour movement. The decision to organise beyond the boundaries of trade or region was unprecedented in 1889, yet came after a decade of inter-colonial co-operation. Reacting to the lack of solidarity between established craft unions and their reluctance to incorporate the growing ranks of unskilled labour, workers in New Zealand (and worldwide) pioneered inclusive and assertive labour federations. ${ }^{5}$ While new unionism generated enthusiasm amongst workers and provoked a wave of counter-mobilisation from nervous capitalists, federated labour remained underfinanced and untested. The 1887 Jubilee affair, John Millar's inspiration for pioneering new models of collective action, revealed the possibilities and pitfalls of his ambitious project. The protracted 'victory' over the Northern line, allowed only by the largesse of Australian unions, maintained, rather than improved pre-strike conditions. $^{6}$

Popularly associated with the rise of new unionism, the London Dock Strike hinted at the movement's weaknesses, as well revealing the impact of newspaper coverage on an industrial dispute and the international dimensions of collective action. Despite the unprecedented mobilisation of 150,000 men, the strike floundered, crippled by a lack of money. Newspapers broadcast the dockers' plight across the British Empire and, suitably encouraged, Australian workers responded with overwhelming generosity, donating over $£ 36,000$. By contrast, New Zealand

\footnotetext{
${ }^{5}$ Larry Peterson, 'The One Big Union in International Perspective: Revolutionary Industrial Unionism, 1900-1925', in James E. Cronin and Carmen Sirianni (eds.), Work, Community, and Power: The Experience of Labour in Europe and America, 1900-1925, Philadelphia: Temple University Press, 1983, pp.51-52.

${ }^{6}$ Atkinson, 'Auckland Seamen and their Union', pp.71-72.
} 
newspapers limited their response to expressions of sympathy, rather than coordinating fundraising efforts, a failure reflected in the paucity of donations wired from New Zealand. To prevail in an industrial dispute, trade unions needed to exert financial pressure on their opponents, either through a general boycott or by depriving the business of labour. Each avenue depended on public support - a boycott required widespread participation to register an effective protest, and a strike needed broad community support. Few workers could survive on their savings for more than a fortnight. Thus, a strike's success depended on organisers' ability to distribute financial assistance among workers' families. Yet, strike relief was costly and unions possessed few assets in $1890 .^{7}$ Thus, the generosity of the wider labour community, the press, and the public was vital to sustain a strike for more than a few weeks. ${ }^{8}$

In early 1890 , the Maritime Council appeared to enjoy the press support required to orchestrate a protracted industrial dispute. Though New Zealand newspapers avoided campaigning on behalf of the London dockers, editors expressed their indignation at the Londoners' wages and working conditions. Similarly, newspapers appeared aghast that 'London style' sweating could occur in New Zealand and condemned instances of union-busting. However, while espousing the principles of trade unionism, both liberal and conservative newspapers condemned their practice. Underlying this approach was the conception of New Zealand as an egalitarian, consensus society - one in which workers' organisation was tolerated, so long as unions remained docile. Thus, the Evening Post encouraged the Wellington textile

\footnotetext{
${ }^{7}$ If strike relief was distributed at a flat rate of $6 \mathrm{~s}$. per day (the wage of an unskilled worker), a month long strike involving 60 workers would cost a union $£ 270$. Yet, 'at best strike pay was a series of inequalities, the amount varying between trades, over places and over time'. Scates, 'Gender, Household and Community Politics', pp.71-72; On 9 September, the New Zealand Herald reported that 'according to the Registrar-General's report, the assets of the Trade Unions in the colony only amount to about $£ 5700$, of which sum $£ 4000$ belongs to the Seamen's Union’. Most unions were considerably less wealthy - on 28 February, the 800 strong Canterbury ASRS reported total capital of $£ 141.14$ s. Clearly even a brief strike would stretch the finances of most New Zealand unions. $N Z H, 9$ September 1890, p.5; LT, 28 February 1890, p.6.

${ }^{8}$ Walker, 'Media and Money', pp.55-56.
} 
workers until they refused binding arbitration, and the New Zealand Herald's support for railway reform faded when the ASRS challenged the Railway Commissioners. ${ }^{9}$ The desire for strong, yet moderate unions was paradoxical. The Otago Daily Times fretted over the Maritime Council's power when it was established, and again during the Shag Point Dispute, but hailed the federation's size as decisive in ending the maritime officers' dispute. ${ }^{10}$ In this idealised view of industrial relations, robust trade unions stood on equal terms with powerful employers, supported by a public eager to maintain an equitable society. If their cause were just, unionists would prevail by virtue of reason. Yet, the stakes were high, and trade unions remained poorly resourced and relatively untested. If confronted by belligerent employers, they had little alternative but to strike or withdraw.

When industrial tensions erupted into conflict in early 1890, the press applied the consensus frame to alienate the striking workers from the reading public. Confronted with the spectre of a railway strike, the New Zealand Herald dismissed the workers' concerns, asserting that 'professional agitators' had provoked the dispute for personal advancement. ${ }^{11}$ The emergence of dedicated union officials allowed workers to organise more effectively. Thus the argument that they fostered radicalism and disrupted the direct 'relationship' between employer and employee - the cornerstone of the 'moderate' approach - had a distinctly anti-labour tone. The appeal of 'moderate' unionism lay in the constant assertion that workers had no quarrel with their employers and that a broad consensus existed on wages and working conditions, disrupted only by the emergence of newly aggressive forms of labour organisation.

Initially limited to the conservative press, the consensus narrative gained traction as the colony's industrial tensions increased. John Millar's overconfident decision to

\footnotetext{
${ }^{9}$ EP, 14 April 1890, p.2; NZH, 20 May 1890, p.4.

${ }^{10} O D T, 28$ October 1889, p.2; ODT, 16 June 1890, p.2.

${ }^{11} \mathrm{NZH}, 20$ May 1890, p.4.
} 
boycott Whitcombe and Tombs enraged conservative papers, while the middle-class liberals who had previously supported the Maritime Council criticised the decision. Even the Lyttelton Times, labour's staunchest ally in the press, considered the declaration a mistake. ${ }^{12}$ The Australian origins of the Maritime Strike, which arrived in New Zealand a fortnight after the abandoned boycott, dominated early reporting of the strike. Thus, the Union Company's provocation of its workforce - hiring nonunion workers in Sydney and Dunedin, in violation of an agreement with the FSU was largely overlooked, as the press repeatedly asserted that a small cadre of agitators had conspired to undermine the domestic consensus. This time the conspirators were Australian labour bosses, directing the strike through their New Zealand lieutenants. Although the liberal press did not abandon the labour cause, middle-class radicals had little fondness for the strike, and devoted their efforts to encouraging conciliation and attacking employers' excesses, rather than contesting the spurious allegation that New Zealand workers had no desire to strike.

While the men remained 'out', the divisions between liberal and conservative newspapers narrowed. The railwaymen's threatened involvement further antagonised the press - only the Lyttelton Times objected to the suppression of dissenting workers by a government agency. ${ }^{13}$ With time, liberal newspapers' support of the strike wavered. Concerned with the fragile West Coast economy, the Grey River Argus advised the Maritime Council to accept defeat and seek a settlement, while the Lyttelton Times stooped to bickering with rival publications. ${ }^{14}$ In mid-September, the widespread syndication of Henry Champion's Melbourne Age article attacking the labour establishment reinforced the perception that Australasian workers welcomed the open shop. As press hostility against the strikers increased, contradictions

\footnotetext{
${ }^{12} L T, 14$ August 1890, p.4.

${ }^{13} L T, 15$ September 1890, p.4.

${ }^{14}$ GRA, 3 October 1890, p.2; LT, 7 October 1890, p.4.
} 
inherent in the dual functions of disseminating news and working to end the strike became apparent. While editorials lamented economic damage wrought by the shipping boycott, reports from across the country emphasised the rapid resumption of work on the wharves. Strike news was typically framed according to its subject assaults on non-union men were considered 'outrages', the reverse 'accidents'. Reporting on the October Labour Conference marked a nadir in the coverage of the strike. Condemned to failure by the withdrawal of all but one of the employers' delegates, the meeting dissolved ignominiously. Despite the employers' obvious disdain for the proceedings, the press held the labour contingent accountable for the failure.

Though the strike continued until 11 November, its final weeks barely featured in the press. While it is often remarked that the Maritime Strike intensified the politicisation of the labour movement, a decade long process by 1890, most newspapers and candidates struggled to comprehend the unprecedented level of worker mobilisation, their failed industrial action, and the ramifications of electoral reform - particularly the 1889 'one-man, one-vote' provision. Atkinson's supporters construed the strike as a fillip for the incumbent government - reminded of the threat that radicals posed to New Zealand's prosperity and social cohesion, voters would reject change. Liberal and labour candidates, and their supporters in the press, implicitly accepted this approach, desperate not to alienate voters. Even in electorates with large populations of trade unionists, labour candidates' manifestos addressed a broad range of 'liberal' issues rather than specific proposals for industrial reform. The ambiguity surrounding the Liberal party, and the complex relationships between local labour candidates and Liberal organisations further obscured the coverage of labour's political ambitions. Furthermore, labour candidates did not have access to the unbounded publicity that newspaper ownership afforded its proprietors - a privilege 
John Ballance, William Pember Reeves, and George Stead enjoyed. Campaign news was scarce, and editors served as 'gatekeeper[s]' of information, mediating readers' exposure to campaign news through the in-house political agenda. ${ }^{15}$ Thus, conservative papers dismissed the notion that labour candidates would enter the House of Representatives, while the liberal press emphasised the unity between labour and Liberal candidates, desperate to preserve the fragile Opposition.

In late October, the publicity generated by the Demonstration Day celebrations, and the moral panic provoked by the fracas at John Duthie's political meeting, gave labour politics a new prominence. The former offered a reminder that the failed strike had not diminished labour's unity; the latter presented the conservative press with a gilt-edged opportunity to convince readers that labour politics threatened the colonial consensus. Duthie's reception at the Wellington Opera House was quickly universalised as newspapers began referring to a cohesive 'labour party' - a term now synonymous with rowdiness, demagoguery, and disorder. By exaggerating the size, strength, and incivility of the labour movement, conservative newspapers sought to portray Sir Harry Atkinson's stolid politics as a necessary corrective to New Zealand's economic and industrial crises.

Although 'liberal' politics implied a 'national' agenda, journalism remained parochial, with most stories focussed on local candidates. However, in the final weeks of the campaign, newspapers addressed the broader significance of the election. Eager for reform, liberal newspapers attempted to heighten public perceptions of colonial stagnation, while attempting to maintain the Liberal coalition of middle-class radicals, smallholders, and trade unionists. When assessing 1890, it is useful to remember Raewyn Dalziel's caution that the 'turning point...was by no

\footnotetext{
${ }^{15}$ Richard Kielbowciz, News in the Mail: The Press, Post Office, and Public Information, 1700-1860s, New York: Greenwood Press, 1989, p.4.
} 
means obvious to those who lived through it'. ${ }^{16}$ However, it is clear that conservative newspapers encouraged this contemporary opacity - seeking to convince the public that the colonial consensus remained firmly intact, challenged only by a ragged bunch of Oppositionists and self-aggrandising trade union leaders. Although grudging admissions of defeat replaced crowing predictions of another term for Atkinson on 6 December, the conservative press refused to capitulate until Parliament met on 23 January.

When, in mid-August, Grey River Argus editor Florence McCarthy remarked on trade unions' inability to communicate with the public, he identified a fundamental problem for the labour movement. ${ }^{17}$ Although he had determined the predicament, McCarthy failed to implicate the controllers of the mainstream press as a barrier to the transmission of ideas and information concerning organised labour. It is important to recognise that from content analyses one can only infer editors' motives in the framing of news stories, whose influence on readers is difficult to determine 120 years after events transpired. ${ }^{18}$ Thus, the extent to which newspapers reinforced social conformity, led public opinion, or reflected the opinions of their audience is often unclear. ${ }^{19}$ However, this study clearly demonstrates the relationship between the press and organised labour, and how competing visions of New Zealand society influenced the production and content of newspapers in 1890. A rigid hierarchy of voices had been established during the commercialisation of the press, and labour activists were at the bottom of the pecking order - portrayed either as renegade voices without a

\footnotetext{
${ }^{16}$ Raewyn Dalziel, 'Towards Representative Democracy: 100 Years of the Modern Electoral System', in Jock Phillips (ed.), Towards 1990: Seven Leading Historians Examine Significant Aspects of New Zealand History, Wellington: GP Books, 1989, p.61.

${ }^{17}$ GRA, 13 August 1890, p.2.

${ }^{18}$ Meg Spratt, 'Science, Journalism, and the Construction of News: How Print Media Framed the 1918 Influenza Pandemic', American Journalism, Vol. 12, no. 3, p.76.

${ }^{19}$ Taylor, 'Contemporary Media Portrayals of the 1913 Dispute', in Nolan (ed.), Revolution, p.144.
} 
popular following, or radical anti-capitalist demagogues. Liberal newspapers' support for the labour cause was equivocal, consisting of hollow rhetoric on moderation and stern disapproval of industrial action. If newspapers such as the Grey River Argus and Lyttelton Times did not publish material written by labour activists, they were unlikely to reach a wide reading audience elsewhere. Labour leaders understood this predicament, but despite the creation of vibrant organisations they lacked the capital to create a communications infrastructure that could sustain the movement in the face of prevailing public and press hostility. Despite the popularity of inter-colonial labour journals, particularly those from Britain and Australia, the lack of a domestic labour periodical remained a problem until the New Zealand Federation of Labour took control of the Maoriland Worker in 1911, a year after the New Zealand Shearers' Federation established the weekly. ${ }^{20}$ Until then, the labour cause remained, as Harry Farnall, editor of the Watchman, warned in 1885, 'like a steamer without a propellerall vapour and no progress'. ${ }^{21}$

\footnotetext{
${ }^{20}$ Between 1890 and 1910, a series of short-lived trade or regional labour periodicals emerged, but no significant national labour newspaper existed. Erik Olssen, The Red Feds: Revolutionary Industrial Unionism and the New Zealand Federation of Labour 1908-1914, Auckland: Oxford University Press, 1988, pp.40-43; Jane Tolerton, Ettie: A Life of Ettie Rout, Auckland: Penguin Books, 1992, pp.66-81.

21 'The 'Watchman", 1885, Roth Papers, MS-Papers 94-106-29/03, ATL.
} 
Appendix One: Employers' Associations, 1890

\begin{tabular}{|l|l|l|}
\hline Location & $\begin{array}{l}\text { Date of } \\
\text { Formation }\end{array}$ & Source \\
\hline Oamaru & 10 July 1890 & North Otago Times, 11 July 1890, p.2. \\
\hline Auckland & 28 August 1890 & Star, 29 August 1890, p.4. \\
\hline Wellington & 29 August 1890 & EP, 29 August 1890, p.2. \\
\hline Gisborne & 3 September 1890 & Poverty Bay Herald, 4 September 1890, p.2. \\
\hline Dunedin & 3 September 1890 & Otago Witness, 4 September 1890, p.19. \\
\hline Napier & 5 September 1890 & EP, 12 September 1890, p.2. \\
\hline Christchurch & 6 September 1890 & Star, 6 September 1890, p.3. \\
\hline Ashburton & 6 September 1890 & Ashburton Guardian, 6 September 1890, p.3. \\
\hline
\end{tabular}

\footnotetext{
${ }^{1}$ Although the Oamaru Farmers' and Employers' Club was established in July, it co-operated with the latterly formed, and larger, Otago Employers' Association in all matters regarding the Maritime Strike and subsequent arbitration conference. North Otago Times, 22 September 1890, p.2.
} 


\section{Appendix Two: Liberal / Labour General Election Manifestos, August - November 1890}

\begin{tabular}{|c|c|c|c|c|c|c|}
\hline Issue & $\begin{array}{c}\text { Political } \\
\text { Manifesto }\end{array}$ & & & & & \\
\hline & $\begin{array}{l}\text { Auckland United } \\
\text { Labour Election } \\
\text { Committee }^{1}\end{array}$ & $\begin{array}{l}\text { Christchurch } \\
\text { People's } \\
\text { Political } \\
\text { Association } \\
\end{array}$ & $\begin{array}{c}\text { John } \\
\text { Ballance's } \\
\text { Manifesto }^{3}\end{array}$ & $\begin{array}{l}\text { Lyttelton } \\
\text { Times } \\
\text { Manifesto }^{4}\end{array}$ & $\begin{array}{l}\text { Otago } \\
\text { TLC }\end{array}$ & $\begin{array}{c}\text { Wellington } \\
\text { TLC }^{6}\end{array}$ \\
\hline $\begin{array}{l}\text { 'Breaking' the large } \\
\text { estates }\end{array}$ & & $\sqrt{ }$ & $\sqrt{ }$ & $\sqrt{ }$ & & $\sqrt{ }$ \\
\hline $\begin{array}{l}\text { Cessation of Crown } \\
\text { land sales }\end{array}$ & $\sqrt{ }$ & & & & $\sqrt{ }$ & $\sqrt{ }$ \\
\hline $\begin{array}{l}\text { Creation of a State } \\
\text { Bank of Issue }\end{array}$ & $\sqrt{ }$ & & & & & \\
\hline $\begin{array}{l}\text { Creation of national } \\
\text { labour tribunals }\end{array}$ & & & $\sqrt{ }$ & $\sqrt{ }$ & & \\
\hline $\begin{array}{l}\text { Eight-hour day } \\
\text { legislation }\end{array}$ & & $\sqrt{ }$ & & $\sqrt{ }$ & $\sqrt{ }$ & \\
\hline $\begin{array}{l}\text { Elected Legislative } \\
\text { Council }\end{array}$ & & $\sqrt{ }$ & & & & $\sqrt{ }$ \\
\hline Estate Tax & & & $\sqrt{ }$ & & $\sqrt{ }$ & $\sqrt{ }$ \\
\hline $\begin{array}{l}\text { Increased honoraria } \\
\text { for MHRs }\end{array}$ & & & & & $\sqrt{ }$ & \\
\hline Industrial protection & & & & $\sqrt{ }$ & $\sqrt{ }$ & $\sqrt{ }$ \\
\hline $\begin{array}{l}\text { Land and Income tax } \\
\text { / Abolition of } \\
\text { property tax }\end{array}$ & $\sqrt{ }$ & $\sqrt{ }$ & $\sqrt{ }$ & $\sqrt{ }$ & $\sqrt{ }$ & $\sqrt{ }$ \\
\hline $\begin{array}{l}\text { Maintenance of } \\
\text { triennial parliaments }\end{array}$ & & $\sqrt{ }$ & & & & \\
\hline $\begin{array}{l}\text { Minimum wage on } \\
\text { government } \\
\text { contracts }\end{array}$ & $\sqrt{ }$ & & & & & \\
\hline $\begin{array}{l}\text { Public works } \\
\text { spending }\end{array}$ & & $\sqrt{ }$ & & $\sqrt{ }$ & $\sqrt{ }$ & \\
\hline $\begin{array}{l}\text { Railway } \\
\text { management reform }\end{array}$ & $\sqrt{ }$ & $\sqrt{ }$ & & & & \\
\hline $\begin{array}{l}\text { Restriction of foreign } \\
\text { contracted labour }\end{array}$ & & & & & & $\sqrt{ }$ \\
\hline $\begin{array}{l}\text { Secular school } \\
\text { system }\end{array}$ & & $\sqrt{ }$ & & $\sqrt{ }$ & & \\
\hline $\begin{array}{l}\text { Utilisation of Crown } \\
\text { lands for settlement }\end{array}$ & $\sqrt{ }$ & & $\sqrt{ }$ & & & \\
\hline
\end{tabular}

\footnotetext{
${ }^{1} \mathrm{NZH}, 1$ November 1890, p.5.

${ }^{2}$ McAloon, 'Radical Christchurch', in Cookson and Dunstall (eds.), Southern Capital, pp.169-70.

${ }^{3} E P, 1$ October 1890, p.2.

${ }^{4}$ McAloon, 'Radical Christchurch', in Cookson and Dunstall (eds.), Southern Capital, pp.169-70.

${ }^{5}$ Olssen, Building the New World, p.181.

${ }^{6} E P, 6$ Monday 1890, p.2.
} 


\section{Bibliography}

\section{Primary Sources:}

Archives and Manuscripts:

Herbert Otto Roth Papers, MS-Group-0314, Alexander Turnbull Library.

\section{Books:}

FitzGerald, J.E., The Representation of New Zealand, Christchurch: Press Office, 1864.

McPherson, James, Reasons Why the Working Men of New Zealand Should Become Internationalists, Together With An Article Entitled Anti-Chinese Immigration, Christchurch: J. McPherson, 1872.

Pharos, Some Historical Articles on Communism and Socialism: Their Dreams, The Experiments, Their Aims, Their Influence, Christchurch: Lyttelton Times, 1890.

Scholefield, Guy H. (ed.), The Richmond - Atkinson Papers, Vol. 2, Wellington: Government Printer, 1960.

\section{Databases:}

Historic Australian Newspapers, 1803 to 1954, [Machine-readable database], Canberra: National Library of Australia [producer and distributor], 2011; http://newspapers.nla.gov.au/.

Papers Past [Machine-readable database], Wellington: National Library of New Zealand Te Puna Mātauranga o Aotearoa [producer and distributor], 2011; http://paperspast.natlib.govt.nz/cgi-bin/paperspast.

Newspapers:

\section{Australia}

Age

Argus

Daily Telegraph

Sydney Morning Herald

\section{Great Britain}

London Standard

The Times

New Zealand

Ashburton Guardian

Evening Post

Grey River Argus 
Lyttelton Times

(1889-1891)

New Zealand Herald

New Zealand Observer and Freelance

North Otago Times

Otago Daily Times

Otago Witness

Otago Workman

Poverty Bay Herald

Press

Star

Tribune

Typo

Wanganui Herald

Yeoman

\section{Official Publications:}

Appendices to the Journals of the House of Representatives of New Zealand New Zealand Parliamentary Debates

Statistics of the Colony of New Zealand

\section{Secondary Sources:}

\section{Books:}

Arnold, Rollo, New Zealand's Burning: The Settlers' World in the Mid 1880s, Wellington: Victoria University Press, 1994.

Arts, A.E.J., A History of the Canterbury Master Printers' Association 1889-1989, Christchurch: Printing Industries Association of Canterbury, 1989.

Atkinson, Neill, Adventures in Democracy: A History of the Vote in New Zealand, Dunedin: University of Otago Press, 2003.

Atkinson, Neill, Crew Culture: New Zealand Seafarers Under Sail and Steam, Wellington: Te Papa Press, 2001.

Atkinson, Neill, Trainland: How Railways Made New Zealand, Auckland: Random House, 2007.

Atkinson, Neill, 'Against the Tide: the Auckland Seamen's Union, 1880-1914', in Pat Walsh (ed.), Trade Unions, Work and Society, Palmerston North: Dunmore Press, 1994, pp.74-90.

Barrowman, Rachel, 'Desmond, Arthur fl.1884-1894', Dictionary of New Zealand Biography; available from http://www.dnzb.govt.nz/dnzb/alt essayBody.asp?essayID=2D9. 
Bassett, Judith, Sir Harry Atkinson, 1831-1892, Auckland: Auckland University Press, 1975.

Belich, James, Making Peoples: A History of the New Zealanders from Polynesian Settlement to the End of the Nineteenth Century, Auckland: Penguin Books, 1996.

Belich, James, Paradise Reforged: A History of the New Zealanders from the $1880 \mathrm{~s}$ to the Year 2000, Auckland: Allen Lane, 2001.

Belich, James, Replenishing the Earth: The Settler Revolution and the Rise of the Anglo-World, New York and Oxford: Oxford University Press, 2009.

Bennett, James, 'Rats and Revolutionaries': The Labour Movement in Australia and New Zealand 1890-1940, Dunedin: University of Otago Press, 2004.

Blainey, Geoffrey, The Tyranny of Distance: How Distance Shaped Australia's History, Sydney: Pan Macmillan, 1966, $2^{\text {nd }}$ edition, 2001.

Bohan, Edmund, 'Blest Madman': Fitzgerald of Canterbury, Christchurch: Canterbury University Press, 1998.

Bohan, Edmund, To Be A Hero: Sir George Grey, 1812-1898, Auckland: Harper Collins, 1998.

Bollinger, Conrad, Against the Wind: the Story of the New Zealand Seamen's Union, Wellington: New Zealand Seamen's Union, 1968.

Bradley, S.W., Newspapers: An Analysis of the Press in New Zealand, Auckland: Heinemann Educational Books, 1973.

Breward, Ian, 'Waddell, Rutherford 1850-1852? - 1932', Dictionary of New Zealand Biography; available from http://www.dnzb.govt.nz/dnzb/alt_essayBody.asp?essayID=2W1.

Brooking, Tom, Lands for the People? The Highland Clearances and the Colonisation of New Zealand: a Biography of John McKenzie, Dunedin: Otago University Press, 1996.

Butterworth, Ruth, 'The Media', in David Novitz and Bill Wilmott (eds.), Culture and Identity in New Zealand, Wellington: GP Books, 1989, pp.142-59.

Chapman, Robert, 'Foreword', in Robert Chapman (ed.), Ends and Means in New Zealand Politics, Auckland: University of Auckland, 1961, pp.1-3.

Cohen, Nancy, The Reconstruction of American Liberalism, 1865-1914, Chapel Hill and London: University of North Carolina Press, 2002.

Condliffe, J.B., New Zealand in the Making: A Study of Economic and Social Development, London: Allen and Unwin, 1930, $2^{\text {nd }}$ revised edition, 1959.

Consedine, Bob, 'Inequality and the Egalitarian Myth', in David Novitz and Bill Willmott (eds.), Culture and Identity in New Zealand, Wellington: GP Books, 1989, pp.172-86. 
Corliss, Paul, Words at Work: An Annotated Bibliography of New Zealand Trade Union Literature, Christchurch: Canterbury University Press, 2006.

Curthoys, Ann, and Markus, Andrew, (eds.), Who Are Our Enemies?: Racism and the Australian Working Class, Neutral Bay: Hale and Iremonger, 1978.

The Cyclopedia of New Zealand [Canterbury Provincial District], Christchurch: Horace J. Weeks Ltd, 1903.

Dalziel, Raewyn, 'Towards Representative Democracy: 100 Years of the Modern Electoral System', in Jock Phillips (ed.), Towards 1990: Seven Leading Historians Examine Significant Aspects of New Zealand History, Wellington: GP Books, 1989, pp.49-63.

Day, Patrick The Making of the New Zealand Press 1840-1800: A Study of the Organizational and Political Concerns of New Zealand Newspaper Controllers, Wellington: Victoria University Press, 1990.

Deneckere, Gita, Goergen, Marie-Louise, Marssolek, Inge, Tartakowsky, Danielle, and Wrigley, Chris, 'May Days', in Jean-Louis Robert, Antoine Prost, and Chris Wrigley (eds.), The Emergence of European Trade Unionism, Aldershot: Ashgate, 2004, pp.141-65.

Dickenson, Jacqueline, Renegades and Rats: Betrayal and the Remaking of Radical Organisations in Britain and Australia, Melbourne: Melbourne University Press, 2006.

Dunn, Waldo Hilary and Richardson, Ivor L.M., Sir Robert Stout: A Biography, Wellington: A.H. \& A.W. Reed, 1961.

Eldred-Grigg, Stevan, New Zealand Working People, 1890-1990, Palmerston North: Dunmore Press, 1990.

Fill, Barbara, Strike: Trouble at t'Mill, Wellington: GP Books, 1989.

Fitzpatrick, B., A Short History of the Australian Labour Movement, Melbourne: MacMillan, 1940, $2^{\text {nd }}$ revised edition, 1968.

Forrest, James, 'Otago During the Goldrushes', in R.F. Walters (ed.), Land and Society in New Zealand: Essays in Historical Geography, Wellington: A.H. \& A.W. Reed, 1965, pp.80-100.

Franks, Peter, Print and Politics: A History of Trade Unions in the New Zealand Printing Industry, 1865-1995, Wellington: Victoria University Press, 2001.

Fry, Eric (ed.), Common Cause: Essays in Australian and New Zealand Labour History, Sydney: Allen and Unwin, 1986.

Gardner, W.J., Prelude to Arbitration in 3 Movements: Ulster, South Australia, New Zealand 1890-1894, Christchurch: Caxton Press, 2009.

Gardner, W.J., 'A Colonial Economy', in Geoffrey W. Rice (ed.) The Oxford History of New Zealand, Auckland: Oxford University Press, 1981, $2^{\text {nd }}$ edition, 1992, pp.57-86. 
Goldsmith, Paul, We Won, You Lost. Eat That! A Political History of Tax in New Zealand Since 1840, Auckland: David Ling, 2008.

Graham, Jeanine, 'Settler Society', in W.H. Oliver and B.R. Williams (eds.), The Oxford History of New Zealand, Auckland: Oxford University Press, 1981, pp.112-39.

Griffiths, George, 'Fenwick, George 1847 - 1929', Dictionary of New Zealand Biography; available from http://www.dnzb.govt.nz/DNZB/alt essayBody.asp?essayID=2F4.

Gustafson, Barry, Labour's Path to Political Independence: the Origins and Establishment of the New Zealand Labour Party, 1900-19, Auckland: Auckland University Press, 1980.

Gustafson, B.S., Constitutional Changes Since 1870, Auckland: Heinemann Educational Books, 1969.

Hamer, D.A., 'Sir Robert Stout and the Labour Question, 1870-1893', in Robert Chapman and Keith Sinclair (eds.), Studies of a Small Democracy: Essays in Honour of Willis Airey, Auckland: Blackwood and Janet Paul, 1963, pp.78-101.

Hamer, David, The New Zealand Liberals: The Years of Power, 1891-1912, Auckland: Auckland University Press, 1988.

Hampton, Mark, Visions of the Press in Britain, 1850-1950, Urbana: University of Illinois Press, 2004.

Harvey, Ross, 'Formula for Success: Economic Aspects of the Nineteenth-Century New Zealand Press', in R. Harvey, W. Kirsop, and B.J. McMullin (eds.), An Index of Civilisation: Studies of Printing and Publishing History in Honour of Keith Maslen, Clayton: Centre of Bibliographical and Textual Studies Monash University, 1993, pp.207-22.

Hawke, G.R., The Making of New Zealand: An Economic History, Cambridge: Cambridge University Press, 1985.

Haimson, Leopold, and Tilly, Charles (eds.), Strikes, Wars and Revolutions in an International Perspective: Strike Waves in the Late Nineteenth and Early Twentieth Centuries, Cambridge: Cambridge University Press, 1989.

Hearn, Mark, and Knowles, Harry, One Big Union: A History of the Australian Workers Union 1886-1994, Melbourne: Cambridge University Press, 1996.

Hickey, P.H., "Red” Fed Memoirs, Wellington: New Zealand Worker Print, 1925.

Hobsbawm, Eric, 'The 'New Unionism' Reconsidered', in Wolfgang J. Mommsen and Hans-Gerhard Husung (eds.), The Development of Trade Unionism in Great Britain and Germany 1880-1914, London: George Allen and Unwin, 1985, pp.13-31. 
Holland, H.E., Labor Leg-Ironed or Liberal and Labor Party Arbitration Acts in N.S.W. With Brief Reference to the New Zealand Arbitration Act, Wellington: The Maoriland Worker, 1912.

Hyman, Richard, 'Mass Organization and Militancy in Britain: Contrasts and Continuities', in Wolfgang J. Mommsen and Hans-Gerhard Husung (eds.), The Development of Trade Unionism in Great Britain and Germany 1880-1914, London: George Allen and Unwin, 1985, pp.250-65.

Jones, Aled, Powers of the Press: Newspapers, Power and the Public in NineteenthCentury England, Aldershot: Scolar Press, 1996.

Jones, S.R.H., Doing Well and Doing Good: Ross and Glendining, Scottish Enterprise in New Zealand, Dunedin: Otago University Press, 2010.

Jones, S.R.H., Ross \& Glendining, Warehouse-Men and Manufacturers: Pioneers in Big Business in Nineteenth Century New Zealand (University of Otago Economics Discussion Paper no. 9513), Dunedin: University of Otago Press, 1995.

Kielbowciz, Richard, News in the Mail: The Press, Post Office, and Public Information, 1700-1860s, New York: Greenwood Press, 1989.

King, Michael, The Penguin History of New Zealand, Auckland: Penguin, 2003.

Kirk, Neville, Labour and Society in Britain and the USA. Volume 2: Challenge and Accommodation, 1850-1939, Aldershot: Scolar Press, 1994.

Lee, Alan J., The Origins of the Popular Press in England 1855 - 1914, London: Croon Helm, 1976.

Lipson, Leslie, The Politics of Equality: New Zealand's Adventures in Democracy, Chicago: The University of Chicago Press, 1948.

Lloyd, Henry Demarest, A Country Without Strikes: A Visit to the Compulsory Arbitration Court of New Zealand, New York: Doubleday, 1900.

Lloyd Prichard, Muriel F., An Economic History of New Zealand to 1939, Auckland: Collins, 1970.

McAloon, Jim, No Idle Rich: The Wealthy in Canterbury and Otago, 1840-1914, Dunedin: University of Otago Press, 2002.

McAloon, Jim, 'Radical Christchurch', in John Cookson and Graeme Dunstall (eds.), Southern Capital, Christchurch: Towards a City Biography 1850-2000, Christchurch: Canterbury University Press, 2000, pp.162-92.

McAloon, Jim, 'The New Zealand Economy, 1792 - 1914', in Giselle Byrnes (ed.), The New Oxford History of New Zealand, Melbourne: Oxford University Press, 2009, pp.197-218.

McCarthy, Terry (ed.), The Great Dock Strike 1889, London: Weidenfeld and Nicolson, 1988. 
McDonald, K.C., City of Dunedin: A Century of Civic Enterprise, Dunedin: Dunedin City Corporation, 1965.

McIvor, Timothy L., The Rainmaker: A Biography of John Ballance, Journalist and Politician, 1839-1893, Auckland: Heineman Reed, 1989.

McLauchlan, Gordon, The Line That Dared: A History of the Union Steam Ship Company 1875-1975, Mission Bay: Four Star Books, 1987.

McLean, Gavin, The Southern Octopus: the Rise of a Shipping Empire, Wellington: New Zealand Ship and Marine Society, 1990.

McRobie, Alan, New Zealand Electoral Atlas, Wellington: GP Books, 1989.

Martin, John, '1890: A Turning Point for Labour', in Pat Walsh (ed.), Pioneering New Zealand Labour History: Essays in Honour of Bert Roth, Palmerston North: Dunmore Press, 1994, pp.21-51.

Martin, John E., Honouring the Contract, Wellington: Victoria University Press, 2010.

Martin, John E., The Forgotten Worker: the Rural Wage Earner in NineteenthCentury New Zealand, Wellington: Allen and Unwin, 1990.

Martin, John E., The House: New Zealand's House of Representatives 1854-2004, Palmerston North: Dunmore Press, 2004.

Mein Smith, Philippa, 'The Tasman World', in Giselle Byrnes (ed.), The New Oxford History of New Zealand, Melbourne: Oxford University Press, 2009, pp.297319.

Mein Smith, Philippa, Hempenstall, Peter, and Goldfinch, Shaun, Remaking the Tasman World, Christchurch: Canterbury University Press, 2009.

Millar, Paul, 'Introductory Note', in Russell Brown (ed.), Great New Zealand Argument: Ideas About Ourselves, Auckland: Activity Press, 2005, pp.48-51.

Miller, John, Early Victorian New Zealand: A Study of Racial Tension and Social Attitudes 1839-1852, Wellington: Oxford University Press, 1958.

Nolan, Melanie, Kin, Christchurch: Canterbury University Press, 2005.

Nolan, Melanie, 'Maritime Strike, Australasia 1890', in Neil Schlager (ed.), St. James Encyclopedia of Labor History: Major Events in Labor History and their Impact, Volume One, Detroit: St. James Press, 2003, pp.587-91

O’Neil, R.B., The Press 1861-1961: The Story of a Newspaper, Christchurch: Christchurch Press Company Limited, 1963.

Oliver, W.H., 'Reeves, Sinclair and the Social Pattern', in Peter Munz (ed.), The Feel of Truth: Essays in New Zealand and Pacific History, Wellington: A.H. \& A.W. Reed, 1969, pp.163-78.

Olssen, Erik, A History of Otago, Dunedin: John McIndoe, 1984.

Olssen, Erik, Building the New World: Work, Politics and Society in Caversham 1880s - 1920s, Auckland: Auckland University Press, 1995. 
Olssen, Erik, and Richardson, Len, 'The New Zealand Labour Movement, 1880 1920', in Eric Fry (ed.), Common Cause: Essays in Australian and New Zealand Labour History, Sydney: Allen and Unwin, 1986, pp.1-15.

Olssen, Erik, The Red Feds: Revolutionary Industrial Unionism and the New Zealand Federation of Labour 1908-1914, Auckland: Oxford University Press, 1988.

Paul, J.T., The Otago Daily Times Diamond Jubilee, 1861-1921: Sixty Years of Achievement. The Press of Otago and Southland, Dunedin: Otago Daily Times and Witness Newspapers Co., 1924.

Pearson, Bill, Fretful Sleepers and Other Essays, London: Heinemann Educational Books, 1974.

Peterson, Larry, 'The One Big Union in International Perspective: Revolutionary Industrial Unionism, 1900-1925', in James E. Cronin and Carmen Sirianni (eds.), Work, Community, and Power: The Experience of Labour in Europe and America, 1900-1925, Philadelphia: Temple University Press, 1983, pp.49-87.

Potter, Simon J., News and the British World: The Emergence of an Imperial Press System, 1876-1922, Oxford and New York: Clarendon Press, 2003.

Reeves, William Pember, State Experiments in New Zealand and Australia, London: Grant Richards, 1902.

Reeves, William Pember, The Long White Cloud, Christchurch: Golden Press, 1898, $4^{\text {th }}$ edition, 1980.

Richardson, Len, Coal, Class and Community: The United Mineworkers of New Zealand, Auckland: Auckland University Press, 1995.

Richardson, Len, 'Lomas, John 1848-1933', Dictionary of New Zealand Biography; available

from http://www.dnzb.govt.nz/DNZB/alt_essayBody.asp?essayID=2L17.

Richardson, Len, and Morris, Gerard, The Denniston Miners' Union: A Centennial History, Westport: Denniston Miners’ Union Centennial Committee, 1984.

Roth, Bert, 'Labour Day in New Zealand', in John E. Martin and Kerry Taylor (eds.), Culture and the Labour Movement, Palmerston North: Dunmore Press, 1991, pp.304-14.

Roth, Bert, Wharfie: "From Hand Barrows to Straddles" Unionism on the Auckland Waterfront, Auckland: The Auckland Branch, New Zealand Waterfront Workers Union, 1993.

Roth, H., 'Trade Unions', in John M. Howells, Noel S. Woods, and F.J.L. Young (eds.), Labour and Industrial Relations in New Zealand, Melbourne: Pittman Pacific Books, 1974.

Roth, H., Trade Unions in New Zealand, Wellington: A.H. \& A.W. Reed Ltd, 1973.

Salmond, J.D., New Zealand Labour's Pioneering Days: the History of the Labour Movement in N.Z. from 1840 to 1894, Auckland: Forward Press, 1950. 
Sanders, James, Dateline - NZPA The New Zealand Press Association 1880 - 1980, Auckland: Wilson \& Horton, 1979.

Scholefield, Guy H., Newspapers in New Zealand, Wellington: A.H. \& A.W. Reed, 1958.

Shannon, R.T., 'The Fall of Reeves, 1893-1896', in Robert Chapman and Keith Sinclair (eds.), Studies of a Small Democracy: Essays in Honour of Willis Airey, Auckland: Blackwood and Janet Paul, pp.127-52.

Sinclair, Keith, A History of New Zealand, Auckland: Penguin, 1959, revised edition, 1988.

Sinclair, Keith, 'Reeves, William Pember 1857-1932', Dictionary of New Zealand Biography; available from

http://www.dnzb.govt.nz/dnzb/alt_essayBody.asp?essayID=2R11.

Sinclair, Keith (ed.), Tasman Relations: New Zealand and Australia, 1788-1988, Auckland: Auckland University Press, 1987.

Sinclair, Keith, The Liberal Government, 1891-1912: First Steps Towards a Welfare State, Auckland: Heinemann Educational Books, 1967.

Sinclair, Keith, 'The Significance of 'the Scarecrow Ministry', 1887-1891', in Robert Chapman and Keith Sinclair (eds.), Studies of a Small Democracy: Essays in Honour of Willis Airey, Auckland: Blackwood and Janet Paul, 1963, pp.102-26.

Sinclair, Keith, William Pember Reeves: New Zealand Fabian, Oxford: Clarendon Press, 1965.

Sinclair, Keith, and Mandle, W.F., Open Account: A History of the Bank of New South Wales in New Zealand, 1861-1961, Wellington: Whitcombe and Tombs, 1961.

Stott, Bob and Leitch, David, New Zealand Railways: The First 125 Years, Auckland: Heinemann Reed, 1988.

Sutch, W.B., The Quest for Security in New Zealand, New York and Wellington: Oxford University Press, 1966.

Svensen, Stuart, The Sinews of War: Hard Cash and the 1890 Maritime Strike, Sydney: University of New South Wales Press, 1995.

Taylor, Frank, The Newspaper Press as a Power Both in the Expression and Formulation of Public Opinion, Oxford: B.H. Blackwell, 1898.

Taylor, James, 'Contemporary Media Portrayals of the 1913 Dispute', in Melanie Nolan (ed.) Revolution: The 1913 Great Strike in New Zealand, Christchurch: Canterbury University Press, 2005, pp.142-63.

Thorn, James, The Formation and Development of Trades Unionism in Canterbury, Wellington: Standard Press, 1950.

Thorns, David C., and Sedgwick, Charles P., Understanding Aotearoa/New Zealand: Historical Statistics, Palmerston North: Dunmore Press, 1997. 
Tolerton, Jane, Ettie: A Life of Ettie Rout, Auckland: Penguin Books, 1992.

Turner, Ian, and Sandercock, Leonie, In Union is Their Strength: A History of Trade Unions in Australia, 1788-1983, Melbourne: Thomas Nelson, 1974, $3^{\text {rd }}$ edition, 1983.

van Voss, Lex Heerma, "“Nothing to Lose but a Harsh and Miserable Life Here on Earth": Dock Work as a Global Occupation, 1790-1970', in Jan Lucassen (ed.), Global Labour History: A State of the Art, Bern: Peter Lang, 2006, pp.591-622.

Waite, Noel, Books for a Nation: The Whitcoulls Story, Auckland: Whitcoulls, 2008.

Waters, Malcolm, Strikes in Australia: A Sociological Analysis of Industrial Conflict, Sydney: Allen \& Unwin, 1982.

Weinstock, Harris, Report on the Labor Laws and Labor Conditions of Foreign Countries in Relation to Strikes and Lockouts, Sacramento: W.W. Shannon, Superintendent State Printing, 1910.

Weir, Robert E., Knights Down Under: The Knights of Labour in New Zealand, Newcastle upon Tyne: Cambridge Scholars Publishing, 2009.

Wilson, J.O. (ed.), A Union Catalogue of New Zealand Newspapers, Preserved in Public Libraries, Newspaper Offices, and Local Authority Offices, Wellington: General Assembly Library, 1938, $2^{\text {nd }}$ edition, 1961.

Wilson, T.G., The Rise of the New Zealand Liberal Party, 1880-90, Auckland: Auckland University College, 1956.

\section{Periodicals :}

Alessio, Dominic, 'Promoting Paradise: Utopianism and National Identity in New Zealand, 1870-1930', New Zealand Journal of History, Vol. 42, no.1, April 2008, pp.22-41.

Charlewood, W.T., 'Labour Troubles in New Zealand', The Economic Journal, Vol. 1, no. 4, December 1891, pp.710-20.

Crawford, John, 'Overt and Covert Military Involvement in the 1890 Maritime Strike and 1913 Waterfront Strike in New Zealand', Labour History, no. 60, May 1991, pp.66-83.

Dickenson, Jacqueline, 'The Greatest Curse and Traitor': H.H. Champion and the Australian Labour Movement, Journal of Australian Studies, no. 80, 2004, pp.189-200.

Donovan, P.F., 'Australia and the Great London Dock Strike', Labour History, no. 23, November 1972, pp.17-26.

Duffy, A.E.P., 'New Unionism in Britain, 1889-1890: A Reappraisal', The Economic History Review, Vol. 14, no. 2, 1961, pp.306-19.

Entman, Robert M., 'Framing: Toward Clarification of a Fractured Paradigm', Journal of Communication, Vol. 43, no. 4, Autumn 1993, pp.51-58. 
Entman, Robert M., 'Framing Bias: Media in the Distribution of Power', Journal of Communication, Vol. 57, no. 1, March 2007, pp.163-73.

Facer, Luke, 'The Introduction of Income Tax in New Zealand', Auckland University Law Review, Vol. 12, 2006, pp.44-70.

Fairburn, Miles, 'New Zealand and Australian Federation, 1883-1901: Another View', New Zealand Journal of History, Vol. 4, no. 2, 1970, pp.138-59.

Frances, Raelene and Nolan, Melanie, 'Gender and the Trans-Tasman World of Labour: Transnational and Comparative Histories', Labour History, no. 95, November 2008, pp.25-42.

Hannis, Grant, 'The New Zealand Press Association 1880 - 2006: The Rise and Fall of a Co-operative Model for News Gathering', Australian Economic History Review, Vol. 48, no. 1, March 2008, pp.47-66.

Harvey, D.R., 'Circulation Figures of Some Nineteenth Century New Zealand Newspapers', Archifacts [Bulletin of the Archives and Records Association of New Zealand], December 1988 and March 1989, pp.20-29.

Harvey, Ross, 'Bringing the News to New Zealand: The Supply and Control of Overseas News in the Nineteenth Century', Media History, Vol. 8, no. 1, 2002, pp.21-34.

Harvey, Ross, 'The Power of the Press in Colonial New Zealand: More Imagined Than Real?", Bibliographical Society of Australia and New Zealand Bulletin, Vol. 17, no. 2, 1993, pp.130-45.

Haydu, Jeffrey, 'Counter Action Frames: Employer Repertoires and the Union Menace in the Late Nineteenth Century', Social Problems, Vol. 46, no. 3, August 1999, pp.313-31.

Greasley, David, and Oxley, Les, 'Globalization and Real Wages in New Zealand 1873-1913', Explorations in Economic History, Vol. 41, no. 1, 2004, pp.26-47.

Greasley, David and Oxley, Les, 'Refrigeration and Distribution: New Zealand Land Prices and Real Wages 1873-1939', Australian Economic History Review, Vol. 45, no. 1, March 2005, pp.23-44.

Markey, Ray, 'New Unionism in Australia, 1880-1900', Labour History, no. 48, May 1985, pp.15-28.

Martin, John E., 'English Models and Antipodean Conditions: the Origins and Development of Protective Factory Legislation in New Zealand', Labour History, no. 73, November 1997, pp.53-75.

Martin, John E., 'Labor History in New Zealand', International Labor and WorkingClass History, no. 49, Spring 1996, pp.166-79.

Martin, John E., 'Political Participation and Electoral Change in Nineteenth-Century New Zealand', Political Science, Vol. 57, no. 1, June 2005, pp.39-58. 
Merritt, J.A., 'W.G. Spence and the 1890 Maritime Strike', Australian Historical Studies, Vol. 15, no. 60, April 1973, pp.594-609.

Nolan, Melanie, 'The Reality and Myth of New Zealand Egalitarianism: Explaining the Pattern of a Labour Historiography at the Edge of Empires', Labour History Review, Vol. 72, no. 2, August 2007, pp.113-34.

Olssen, Erik, 'The 'Working Class' in New Zealand', New Zealand Journal of History, Vol. 8, no. 1, May 1974, pp.44-61.

Olssen, Erik, 'Where to From Here? Reflections on the Twentieth-Century Historiography of Nineteenth-Century New Zealand', New Zealand Journal of History, Vol. 26, no. 1, April 1992, pp.54-77.

Roth, Bert, 'A History of Socialist Newspapers in New Zealand', Socialist Action, Vol. 8, no. 7, May 1976, p.4.

Scates, Bruce, 'Gender, Household and Community Politics: The 1890 Maritime Strike in Australia and New Zealand', Labour History, no. 61, November 1991, pp.70-87.

Shannon, R.T., 'The Liberal Succession Crisis in New Zealand, 1893', Historical Studies of Australia and New Zealand, Vol. 8, no. 30, 1958, pp.183-201.

Simpson, Tony, 'The Holt Narrative and the Industrial Relations Agenda', New Zealand Journal of Industrial Relations, Vol. 12, no. 3, 1987, pp.143-50.

Spratt, Meg, 'Science, Journalism, and the Construction of News: How Print Media Framed the 1918 Influenza Pandemic', American Journalism, Vol. 12, no. 3, pp.61-79.

Traue, J.E., 'But Why Mulgan, Marris and Schroder?: The Mutation of the Local Newspaper in New Zealand's Colonial Print Culture', Bibliographical Society of Australia and New Zealand Bulletin, Vol. 21, no. 2, 1997, pp.107-15.

Ville, Simon, 'The Coastal Trade of New Zealand Prior to World War One', New Zealand Journal of History, Vol. 27, no. 1, April 1993, pp.75-89.

Walker, R.B., 'Media and Money: The London Dock Strike of 1889 and the Australian Maritime Strike of 1890', Labour History, no. 41, November 1981, pp.41-56.

\section{Broadcasts:}

Rose, Jeremy, Ideas: Globalised Labour, Radio New Zealand National, 24 October 2010.

\section{Conference Papers:}

Nolan, Melanie, 'AAustralasian Assignations?' The Impact of the '1890' Generation and the Maritime Strike on later Trans-Tasman Unionism', in Frances Laneyrie and Raymond Markey (eds.), Globalisations and Labour in the Pacific: Re- 
evaluating the 1890 Maritime Strike Symposium Proceedings, Auckland: New Zealand Work and Labour Market Institute, 2010, pp.53-65.

\section{Unpublished Manuscripts:}

Easton, Brian, Not in Narrow Seas: New Zealand History from an Economic Perspective, unpublished manuscript, 11 September 2010.

\section{Unpublished Theses:}

Angus, John H., 'City and Country, Change and Continuity: Electoral Politics and Society in Otago, 1877-1893', PhD Thesis, University of Otago, 1976.

Atkinson, Neill, 'Auckland Seamen and their Union, 1880-1922', MA thesis, University of Auckland, 1990.

Bennett, James, 'The 1890 Maritime Strike and the Triangular Relationship Between Britain, Australia and New Zealand', MA thesis, University of Canterbury, 1986.

Campbell, Christopher, 'Parties and Special Interests in New Zealand 1890-1893', MA thesis, Victoria University of Wellington, 1978.

Hepburn, Laurel Elizabeth, 'The Attitudes of the Newspapers in Canterbury to the Emergent Labour Movement, and Related Issues, from 1885 to 1890', MA thesis, University of Canterbury, 1985.

McIvor, Timothy J., 'On Ballance: A Biography of John Ballance, Journalist and Politician, 1839-1893', PhD Thesis, Victoria University of Wellington, 1984.

Merrett, Ian A., 'A Reappraisal of the 1890 Maritime Strike in New Zealand', MA thesis, University of Canterbury, 1969.

Mitchell, Peter Alexander, 'John Andrew Millar and the New Zealand Labour Movement', MA thesis, Victoria University of Wellington, 1948.

Murrihy, Lesley Ruth, 'The Myths and the Portrayal of New Zealand National Character in Nineteenth Century Pioneer Novels', MA thesis, Victoria University of Wellington, 1984.

Salmond, J.D., 'The History of the New Zealand Labour Movement From the Settlement to the Conciliation and Arbitration Act 1894', MA thesis, University of Otago, 1924.

Whitehead, Clive, 'The 1887 General Election in Canterbury', MA thesis, University of Canterbury, 1961. 